\title{
Nanoremediation Technologies for sustainable remediation of contaminated environments: Recent advances and challenges
}

\author{
Adil Shafi', Sayfa Bano', Nishat Khan', Saima Sultana ${ }^{1}$, Zubair Rehman', Mohammed M. Rahman', \\ Suhail Sabir ${ }^{1}$, Frederic Coulon ${ }^{4}$ and Mohammad Zain Khan ${ }^{1 *}$
}

${ }^{1}$ Environmental Research Laboratory, Department of Chemistry, Aligarh Muslim University, Aligarh-202002, Uttar Pradesh, India

${ }^{2}$ Section of Organic Chemistry, Department of Chemistry, Aligarh Muslim University, Aligarh-202002, Uttar Pradesh, India

${ }^{3}$ Center of Excellence for Advanced Material Research (CEAMR), King Abdulaziz University, Jeddah 21589, Saudi Arabia

${ }^{4}$ School of Water, Energy and Environment, Cranfield University, Cranfield, MK43 0AL, United Kingdom

*Corresponding Author : Mohammad Zain Khan, E-mail: dr_mzain.fa@amu.ac.in

\begin{abstract}
A major and growing concern within society is the lack of innovative and effective solutions to mitigate the challenge of environmental pollution. Uncontrolled release of pollutants into the environment as a result of urbanisation and industrialisation is a staggering problem of global concern. Although, the eco-toxicity of nanotechnology is still an issue of debate, however, nanoremediation is a promising emerging technology to tackle environmental contamination, especially dealing with recalcitrant contaminants. Nanoremediation represents an innovative approach for safe and sustainable remediation of persistent organic compounds such as pesticides, chlorinated solvents, brominated or halogenated chemicals, perfluoroalkyl and polyfluoroalkyl substances (PFAS), and heavy metals. This comprehensive review article provides a critical outlook on the recent advances and future perspectives of nanoremediation technologies such as photocatalysis, nano-sensing etc., applied for environmental decontamination. Moreover, sustainability assessment of nanoremediation technologies was taken into consideration for tackling legacy contamination
\end{abstract}


with special focus on health and environmental impacts. The review further outlines the ecological implications of nanotechnology and provides consensus recommendations on the use of nanotechnology for a better present and sustainable future.

Keywords: Nanoremediation, environmental sustainability, persistent organic pollutants, photocatalysis, nano-sensors 


\section{Introduction}

Environment sustainability is the responsible and justified interaction between human beings and the environment with judicious use of natural resources that can render the environment safe for present as well as for future generations. The controlled management of natural resources emphasises harmony between ecology and environment and can sustain the ecological/natural balance within the universe (Barrington-Leigh, 2016; Arora et al., 2018). According to United Nations World Summit 2005, sustainable development has social, environmental and economic aspects. Environmental sustainability is intimately related to economic sustainability (Haapanen and Tapio, 2016). According to UN Environment Annual Report 2017, environmental sustainability is essential for global equity, liberty and security. Sustainability is not only holistic, attractive and elastic but imprecise (IUCN, 2006). Among the several agendas, Environmental sustainability and economic security were the main goals highlighted by United Nations Sustainable Development Goals (SDGs), framed on September 15, 2015 (Arora and Mishra, 2019). The Sustainable Remediation Forum for the UK (SuRF-UK) established the consideration of sustainability aspect in remediation of contaminated land and come up with sustainability criteria or checklist for framing a remediation planning. The SuRF-UK indicator checklist provides detailed and comprehensive guidance for checking the sustainability assessment of remediation process. From a decade now, the SuRF-UK sustainability assessment is accepted as crucial to remediation planning and implementation around the world (Bardos et al., 2018).

Despite of its prime importance, the environmental sustainability has remained a non-trivial challenge because of climate change, global warming, resource depletion and disturbances associated with biodiversity. In a recent, Global Sustainable Development Report (GSDR, 2019), it was stated, that both present as well as future of the globe are at risk, no country in 
the world is at a position to achieve the United Nations Sustainable Development Goals (SDGs)s by 2030 (Sachs et al., 2019). According to World Water Development Report (2019), the water consumption rate has increased by $1 \%$ per year from 1980 and is expected to reach 3\% by 2050 (World Water Development Report 2019 | UN-Water). The other major setbacks to the environmental sustainability are consumption of fossil fuels and climate change, the consumption of fossil fuels has almost doubled from past 20 years (https://ourworldindata.org/fossil-fuels). The world temperature will raise $3-5^{\circ} \mathrm{C}$ by 2050 , if uncontrolled release of greenhouse gases had not been checked, as reported by UN World Meteorological Organization. Therefore, there is an urgent need to develop sustainable and eco-friendly approaches for sustaining the viability and sustainability of this planet (Abhilash et al., 2016; Cai et al., 2019; Shields et al., 2019).

A great deal of research is currently underway for developing and designing efficient and reliable techniques to degrade or transform environmental pollutants of concern. Specifically, the use of nanomaterials in environmental remediation have gained much attention due to their unusual characteristics viz cost-effectiveness, sensitivity, excellent electronic properties, high surface to volume ratio and better catalytic properties (Ghasemzadeh et al., 2014; Khan et al., 2019).

Nanoremediation is an innovative remediation technique that relies on the use of nanomaterials. Nanoremediation allows to tackle and address the formidable challenges of $21^{\text {st }}$ century such as pollution crisis, contaminated land management, restoration of environmental imbalance and presents innovative solutions for quick and efficient removal of pollutants from contaminated environment (Das et al., 2019; El-Ramady et al., 2017; Singh and Ambika, 2018). The technologies employing nanostructures has potential not only to reduce the overall costs of cleaning up large scale contaminated, but also to reduce clean-up 
time, eliminate the need for treatment and disposal of contaminated materials, and reduce contaminant concentration to near zero- all in situ (Corsi et al., 2018; Karn et al., 2009). Nanoremediation technologies entails the applications of reactive nanomaterials such as metal oxides, nanodots, bimetallic nanoparticles, carbon nanotubes, nanoclusters and nanocomposites for the degradation and mineralisation of contaminants (Guerra et al., 2018; Khin et al., 2012; Gehrke et al., 2015; Rajan, 2011). Compared to several traditional remediation methods such as chemical oxidation, solvent co-flushing, pump treat method and thermal decomposition, nanoremediation approaches can provide sustainable solutions to the environmental pollution problems and could depreciate the financial burden for clean-up of contaminated sites (Caliman et al., 2011; Yeung, 2010; Khan et al., 2019; Patil et al., 2016).

According to reports published on the USEPA and environmental nanotechnology website, various contaminated sites have been treated using nanoremediation approaches over the last decade. It has been shown that nanoremediation resulted in drastic reduction in operational costs, by almost $80 \%$ and significant reduction of time frame in treating contaminated sites as compared to conventional remediation methods (USEPA 2009, PEN, 2015). The global investment in nano-enabled devices and products have increased nine-fold from \$US 432 million to \$US 4100 million in only 8-year time span (1997-2005) (Roco, 2005). In recent years, nanotechnology has influenced all fields of science and technology like engineering, medical, electronics, optics, energy and environmental fields, increased number of nanotech products are circulating in the market with 3-4 items added per weak (Bondarenko et al., 2013). In 2015, the nanotechnology market in Asia was estimated to be $\$ 14741.6$ million and has been expected to reach $\$ 55056$ million by 2022 with compound annual growth rate (CAGR) increase of $20.7 \%$. According to nanotechnology 2020 market analysis, Asia-pacific is the most attractive market for nanotechnology due to the vast demand for potential nanomaterials. (Figure 1) 




Figure 1. Global nanotechnology market analysis report, 2020, showing the statistics of utilization of nanotech-based products around the globe

Nanotechnology enables the manipulation of matter at nano-dimensions where unique phenomena enable novel applications (Shafi et al., 2020a; Omar, 2018; Vikesland, 2018). Nanotechnology ensures the in-situ remediation of contaminated media without adding further chemicals (Karn et al., 2009). The technology at nano level involves the use of reactive nanomaterials with high surface area, lower reduction potential and quantum confinement which makes them versatile entities for degradation, detoxification and transformation of hazardous recalcitrant pollutants in the environmental medias (Fajardo et al., 2020; Gil-Díaz et al., 2019; Patil et al., 2016; Tosco et al., 2014). These nanomaterials in form of catalysts, chemical oxidants, nanosensors, adsorbents ensure rapid detection and simultaneous detoxification of contaminants such as chlorinated biphenyls, pesticides, drugs, aromatic heterocycles, volatile organic compounds, heavy metals, inorganic ions from water, air and contaminated land sites (Chaudhry et al., 2008; Cui et al., 2001). Environmental 
applications of nano-based materials have received public attention and needs to be elaborated with special focus on sustainability assessment of remediation proposal (Thangavel and Sridevi, 2015; Bouqellah et al., 2019; Das and Chatterjee, 2019; Khan et al., 2015).

This review outlines the application of nanotechnology in 1) photocatalytic processes for energy production and environmental restoration, 2) detection and quantification of trace contaminants from environment using nanosensors, 3) groundwater, wastewater and contaminated soil remediation using nanoadsorbents and nanocatalysts. Furthermore, the sustainability assessment was taken into consideration for tackling contamination legacy with special focus to health and environmental impacts.

\section{Nano-Photocatalysis in environmental remediation: A sustainable approach}

Persistent organic pollutants in the environment are not readily degraded and therefore persist for long times and ultimately find their way into the food chain, thus causing severe detrimental effects to human beings (Ashraf, 2017). Due to inability of conventional treatment technologies to degrade recalcitrant organic compounds completely, the level of pollutants in the environment is rising day by day. Researchers in collaboration with governmental and nongovernmental agencies have devoted their constant efforts to mitigate the increasing pollution level by developing smarter and eco-friendly techniques (Anjaneyulu et al., 2005; Bates et al., 2016; Ludlow and Roux, 2012). Photocatalytic technique is one among them, by which the use of highly reactive hydroxyl and superoxide radicals can convert the hazardous materials into environmental benign products. Photocatalysts speeds up the chemical reaction in ample presence of solar radiations. In general, Photocatalysis is a redox reaction on the surface of photocatalyst brought about by valence band (holes, $\mathrm{h}^{+}$) and conduction band (electrons, $\mathrm{e}^{-}$) produced by the absorption of photons. Upon irradiation holes are generated in valence band (VB) and electrons in conduction band (CB) of a photocatalyst, such photogenerated electron- 
hole pairs $\left(\mathrm{e}^{-} / \mathrm{h}^{+}\right)$induces the formation of highly energetic and reactive species such as hydroxyl $\left(\mathrm{OH}^{-}\right)$and superoxide radicals $\left(\mathrm{O}_{2}^{-}\right)$. The reactive species are enough potent to oxidize organic pollutants, decompose the air pollutants such as $\mathrm{NO}_{2}, \mathrm{CO}$ and $\mathrm{NH}_{3}$, degrade the waste plastics and destruct all water borne microbes. Photocatalysis has been considered as a productive procedure for the mineralization of hazardous chemical substances, unsafe inorganic materials and microbial disinfection because of the generation of highly energetic radicals which act as powerful oxidizing agent (Ajmal et al., 2014; Khin et al., 2012). The diagrammatic representation of photocatalytic mechanism is depicted in Figure 2.

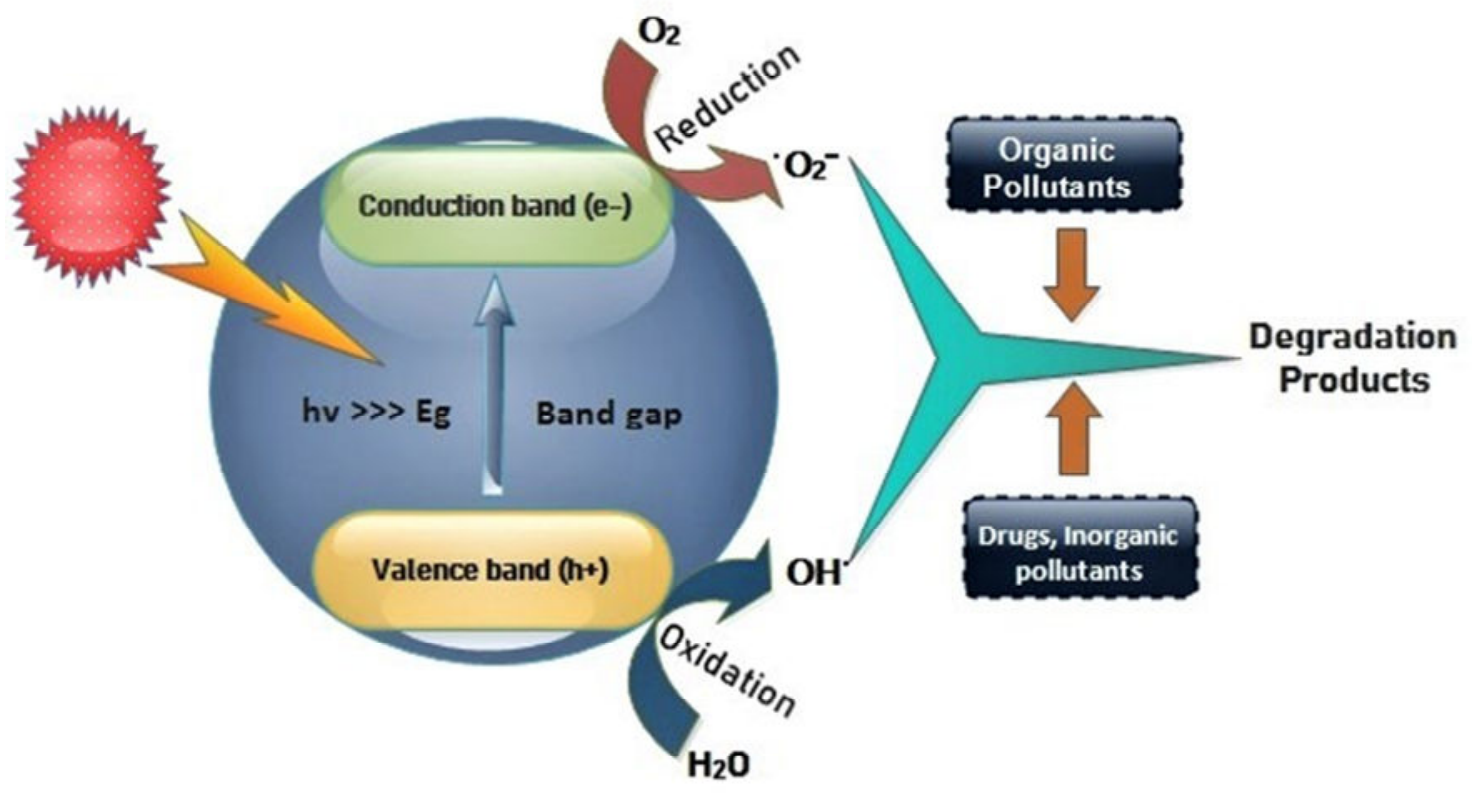

Figure 2. General Mechanism of photocatalysis, depicting the generation of holes $\left(\mathrm{h}^{+}\right)$and electrons (e-) and subsequent degradation of pollutants by utilizing solar light.

The photo catalytic oxidation of hydrocarbons, phenols, aldehydes, halo-compounds, surfactants, dyes, drugs, pesticides, etc demonstrates the efficient clean-up process for maintaining the health of environment (Charanpahari et al., 2018; Hoffmann et al., 1995). From the last decade extensive research has been focussed on nanomaterial photocatalysis for environmental clean-up. A vast number of photocatalysts in their nanoform have been developed like metal oxides, metal sulphides, composite oxides, carbon nanotubes, dendrimers, 
polymeric nanocomposites etc. to decontaminate soil, purify air and detoxify wastewater (Das et al., 2015; Khan et al., 2015; Krishnan et al., 2017; Mahlambi et al., 2015).

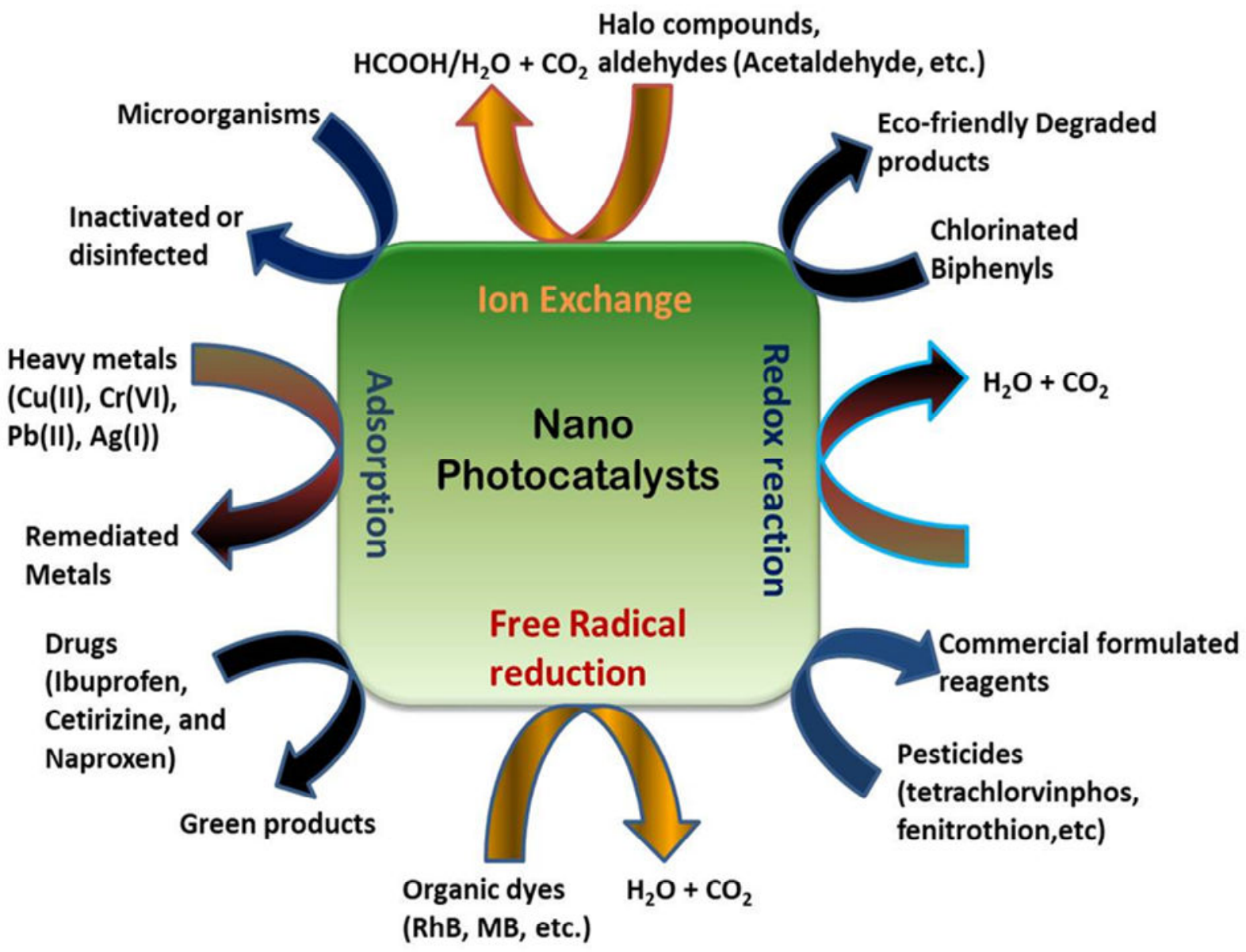

Figure 3. Photocatalytic degradation of various pollutants by sustainable approaches using metallic nanoparticles

Photocatalysis is a photochemical process based on redox reactions of electron/hole pairs upon irradiation (Guo et al., 2018; Kiriakidis and Binas, 2014). Photocatalysis has the potential to degrade plethora of recalcitrant pollutants as depicted in Figure $\mathbf{3}$ and is considered as an efficient remediation technique as per sustainability perspective of the environment (Arora et al., 2016; Khan et al., 2015). This technique is considered as a potential advanced oxidation technology (AOP) to culminate demanding problems of air contamination, energy restoration and water disinfection. Due to rapid degradation rates, 
complete conversion of organic compounds to green products and simultaneous treatment of multiple contaminants, AOPs such as photocatalysts proved to be smart alternatives to mitigate environmental problems in comparison to conventional treatment methods (Jiang et al., 2012; Krishnan et al., 2017).

Furthermore, photo catalytic water splitting has proved to be safer, cleaner and sustainable approaches to generate molecular hydrogen. Hydrogen is considered as the promising and sustainable alternate for consumption of fossil fuels as the only product that it forms during combustion is water (Rosen and Koohi-Fayegh, 2016; Takata and Domen, 2019; Wolff et al., 2018). Research on formation of molecular oxygen or molecular hydrogen through photocatalytic water splitting is at the cutting edge to mitigate the burning problem of energy crisis. Several photocatalysts have been investigated for molecular hydrogen production or oxygen evolution reactions but most of the photocatalysts suffer a severe drawback of low efficiency. Metal oxides, sulphides, nitrides, conjugated organic polymers, carbon based photocatalysts are seen as an efficient photocatalysts for water splitting or hydrogen production (CdSe, $\mathrm{CdS}, \mathrm{Ta}_{3} \mathrm{~N}_{5}, \mathrm{TaON}, \mathrm{C}_{3} \mathrm{~N}_{4}, \mathrm{SiC}, \mathrm{BiVO}_{4}, \mathrm{WO}_{3}, \mathrm{Cu}_{2} \mathrm{O}, \mathrm{Fe}_{2} \mathrm{O}_{3}, \mathrm{~g}-\mathrm{C}_{3} \mathrm{~N}_{4}$ nanosphere, TFPT-covalent organic framework, Polymer P7) (Landman et al., 2017; Y. Li et al., 2019; N. Liu et al., 2015). However, the efficiency can be somewhat less due to electronhole recombination and photocorrosion. Therefore, modified photocatalysts such as bimetallic nanoparticles, hierarchical nanostructures, nanocomposites, oxynitrides and functionalized nanoparticles can prove excellent candidates for water splitting reactions because of better charge separation and synergism for photoabsorption (Wang et al., 2019). The mechanism of photo catalytic water splitting along with generation and recombination of photo-induced charge carriers is depicted in Figure 4. 


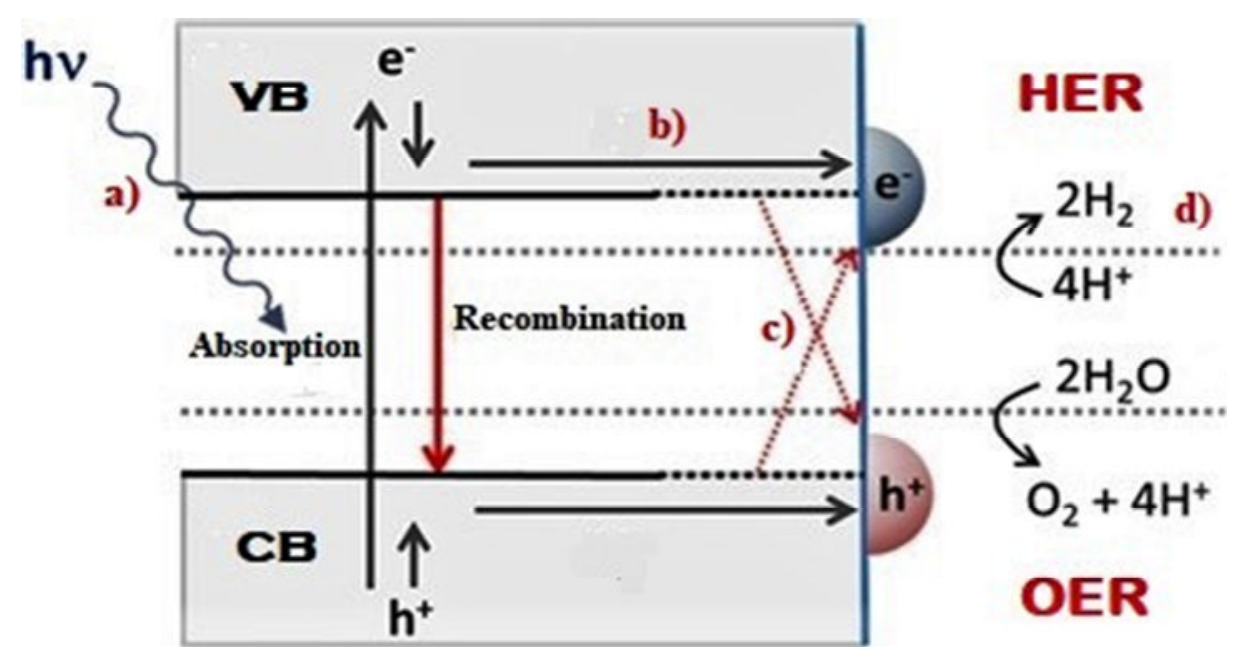

Figure 4. Reaction scheme of photocatalytic water-splitting on the surface of heterogeneous photocatalyst: a) absorption b) charge transfer c) redox reactions d) charge recombination. Reproduced From (Axet et al., 2019)

Recently, a new finding based on the interaction between photocatalysts and microorganisms has opened a general pathway for sustainable remediation of environmental pollutants and has explored the sustainable growth of photocatalysts as well (Deng et al., 2020). Based on the extensive literature, three types of interactions were established between photocatalysts and microorganisms as follows: 1) photocatalytic damage to microorganisms which includes sterilisation of microorganisms and disinfection of public environment. 2) Synergistic effect of photocatalysts on microorganism which includes altruistic collaboration for degradation of pollutants and generation of energy in a sustainable manner. 3) Preparation of photocatalysts with the aid of microorganisms as a greener and sustainable approach. The coupling of photocatalytic technology (photoanode) with bio-electrochemical systems (biocathode) can degrade the organic pollutants in a sustainable manner and enhance the production of hydrogen and generation of electricity. Du et al., (2017) reported the combination of photocatalytic anode with biocathode, $\mathrm{CNT} / \mathrm{TiO}_{2}$ was fabricated by decorating CNT with $\mathrm{TiO}_{2}$ nanoparticles. This biocathode coupled photochemical battery (Bio-PEC) shows efficient degradation of methylene blue $\left(0.0120 \mathrm{~min}^{-1}\right)$ and excellent power density of 
(211.32 $\mathrm{mW} \mathrm{m}^{-2}$ ). Sakimoto et al., (2016) investigated the coupling of highly specific biocatalysts with the efficient photocatalytic semiconductor. The study involves the use of cadmium sulphide (CdS) nanoparticles to autosensitise Moorella thermoacetica, thus producing acetic acid with the utilisation of carbon dioxide in photosynthesis. The photoelectrons transferred from photocatalyst to the bacteria add to $\mathrm{CO}_{2}$ and undergoes several reaction pathways inside the bacteria to produce acetic acid. Marsolek et al., (2008) proposed the concept of coupling of photodegradation to biodegradation (ICPB). This Photo catalytic coupled microorganism system is a novel remediation method for treatment of refractory wastewater in a sustainable manner. Moreover, the microbial assisted photocatalytic preparation involves the use of electrochemical active biofilms (EAB) to facilitate efficient electron transfer and improves the photocatalytic performances (Khan et al., 2014). The possible interactions between photocatalysts and microorganisms are also shown in Figure 5. 


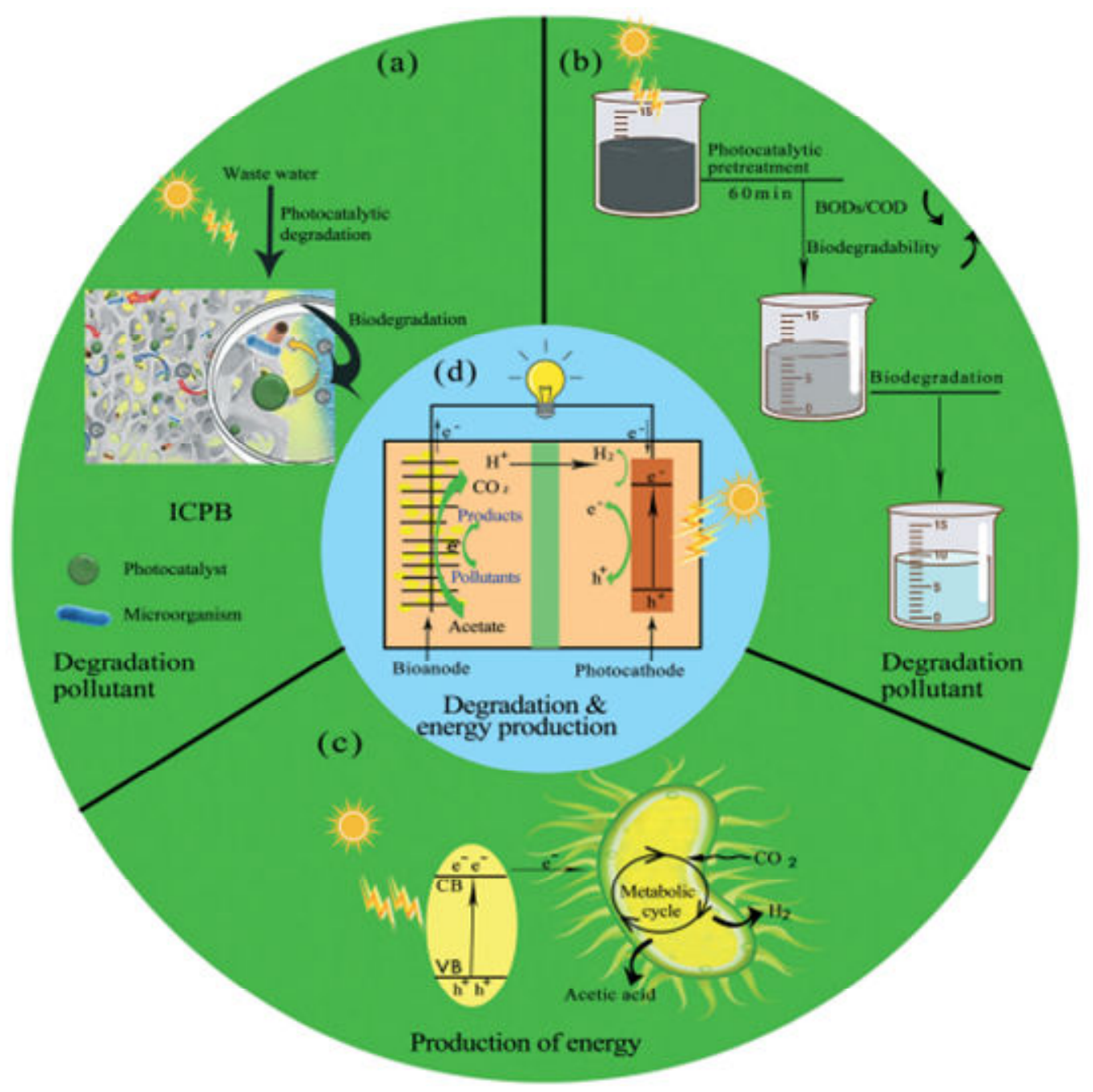

Figure 5. (a) Photocatalytic coupling of microbial degradation of pollutants (ICPB). (b) Photocatalytic retreatment of pollutants in wastewater enhances the biodegradability of refractory materials. (c) Microbes use photogenic electrons to make valuable chemicals through their own metabolic cycles. (d) Photocatalysts as electrode materials to improve the degradation of pollutants and power generation performance of bioelectrochemical systems. Reproduced from (Deng et al., 2020)

An ideal photocatalyst should possess high surface to volume ratio, proper band gap, high porosity, quantum confinement, reliability and long term stability. Nanomaterials which are depicted in Table 1 are considered as ideal photocatalysts because of desired features viz high surface area, high reactivity, rapid diffusion, easy dispersibility and sustainable 
environmental remediation approach. Titanium dioxide $\left(\mathrm{TiO}_{2}\right)$ is considered as an efficient photocatalyst because of its potential catalytic activity, chemical stability and non-toxicity (Diamandescu et al., 2008; Fujishima et al., 2000; Gupta and Tripathi, 2011). To date, several research articles have been published on $\mathrm{TiO}_{2}$, explaining its fascinating characteristics in photocatalytic hydrogen production, air purification, and water disinfection. Kato and Mashio, (1964) reported photocatalytic oxidation of tetralin (1,2,3,4-tetrahydronaphthalene), a potent human mutagen and toxic chemical by a $\mathrm{TiO}_{2}$ suspension. Sonawane et al., (2004) investigated $\mathrm{Fe}$-doped $\mathrm{TiO}_{2}$ for photodegradation of methyl orange and it was found to degrade $95 \%$ of methyl orange after 2-3 hours exposure of sunlight. Rocha et al., (2010) carried out efficient degradation and mineralisation of organic matter in oil sludge by heterogeneous catalysis of $\mathrm{H}_{2} \mathrm{O}_{2} / \mathrm{UV} / \mathrm{TiO}_{2}$, indicating the catalytic behaviour of $\mathrm{TiO}_{2}$. Yang and Yang, (2018) carried out complete degradation of rhodamine B dye, almost $99 \%$ through the photocatalytic behaviour of anatase $\mathrm{TiO}_{2}$. Mahmoodi et al., (2007b), (2007a) reported the efficient catalytic behaviour of immobilized $\mathrm{TiO}_{2}$ nanoparticles in decomposition of agricultural pollutants such as diazonin, Butachlor (N- butoxymethyl-2-chloro-2,6diethylacetanilide), imidacloprid as $\mathrm{N}$-heterocyclic aromatics $\mathrm{In}$ addition to $\mathrm{TiO}_{2}$, several metallic nanomaterials are investigated for potential photocatalytic applications like $\mathrm{ZnO}$ (Rajamanickam and Shanthi, 2016), ZnS (Ahmadi et al., 2020), $\mathrm{ZrO}_{2}$ (Botta et al., 1999), $\mathrm{MoS}_{2}$ (Li et al., 2013), $\mathrm{WO}_{3}$ (Dong et al., 2017), CdS (Su et al., 2018), $\mathrm{Fe}_{2} \mathrm{O}_{3}$ (Rincón Joya et al., 2019), $\mathrm{Cu}_{2} \mathrm{O}$ (Bhargava and Khan, 2018), 2D $\mathrm{PbMoO}_{4}$ (Datta et al., 2018), $\mathrm{NaNbO}_{3}$ (Shi et al., 2011), $\mathrm{CdIn}_{2} \mathrm{~S}_{4}$ (Huang et al., 2014), $\mathrm{ZnIn}_{2} \mathrm{~S}_{4}$ (Huang et al., 2014). $\mathrm{ZnO}$ being inexpensive and non-toxic shares the same photodegradation mechanism as $\mathrm{TiO}_{2}$ and is considered as potential photocatalyst for environmental remediation. $\mathrm{ZnO}$ is an n-type semiconductor with excellent electronic properties and exhibits better absorption efficiency compared to $\mathrm{TiO}_{2}$ (Bai et al., 2013; Wang et al., 2011). Tian et al (2012) performed the 
photodegradation of methylene orange by two photocatalysts, Degussa $\mathrm{P} 25 \mathrm{TiO}_{2}$ and $\mathrm{ZnO}$ and it was reported that the degrading power of $\mathrm{ZnO}$ was 4 times more than that of $\mathrm{P} 25$. However, the photocatalytic activity of $\mathrm{ZnO}$ is somehow affected because of its large band gap energy. Therefore, several efforts have been taken to mitigate the limitation and enhance the absorption efficiency of $\mathrm{ZnO}$ viz, incorporation of dopants, composite formation, dye sensitization and surface decoration with active materials. It has been investigated that the dopants such as silver, aluminium, tin, cobalt, reduced graphene oxide, graphite like $g-\mathrm{C}_{3} \mathrm{~N}_{4}$ can increase the photocatalytic activity of $\mathrm{ZnO}$ by measurable factors and can improve its practical application in multiple fields (Nguyen et al., 2019; Wu et al., 2011). Furthermore, composites of carbon source $\left(\mathrm{GO}, \mathrm{g}-\mathrm{C}_{3} \mathrm{~N}_{4}\right)$ with $\mathrm{Ag}, \mathrm{Zn}$ and other transition metals exhibited promising properties for mineralization of organic pollutant. Reduced GO have the capability of lowering band gaps and prevent agglomeration of nanoparticles because of its excellent electron transfer properties, thus boosts the photocatalytic activity (Wang et al., 2011). Xu et al., (2018) designed quaternary composites of $\mathrm{ZnO}$ nanorod/RGO/CuInS $\mathrm{S}_{2}$ quantum dots which exhibit enhanced photocatalytic activity under visible light irradiation. Divya et al., (2017) synthesized $\mathrm{TiO}_{2} / \mathrm{ZnO} / \mathrm{RGO} / \mathrm{Ag}$ quaternary nanocomposites which can photodegrade almost $99 \%$ of organic pollutant (Rhodamine B) under visible light with excellent recyclability. It has also been reported, that ZnO/RGO@NF showed high photocatalytic efficiency for the degradation of Malachite green (MG) and efficient photocatalytic performance for continuous operations, showing its great potential as stable and promising catalyst for the efficient removal of MG in seawater (N. Liu et al., 2015).

The investigation of synthetic route and potential application of various other nanomaterials have been reviewed and are shown in Table 1. The applicability of various photocatalysts is restricted by their wide band gap and fast recombination of photogenerated electron-hole pairs. To overcome this difficulty, various approaches were employed to tailor the band gap of 
photocatalysts such as doping, dye-sensitization, formation of heterojunctions and capping, etc. It has been reported that that doping a photocatalyst with suitable dopant can inhibit the electron-hole pair recombination resulting in separation of photogenerated species and thus enhance the photocatalytic activity (Akir et al., 2017; He et al., 2018).

Table 1. List of metal-based nano-photocatalysts and their use in environmental remediation

\begin{tabular}{|c|c|c|c|c|}
\hline NM type & Synthetic Method & $\begin{array}{l}\text { Light used for } \\
\text { Irradiation }\end{array}$ & Environmental Applications & Literature \\
\hline $\mathrm{Ag}_{2} \mathrm{~S} / \mathrm{Bi}_{2} \mathrm{WO}_{6}$ & Hydrothermal method & Visible light & RhB Degradation & $\begin{array}{l}\text { (Mehraj et al., } \\
\text { 2015b) }\end{array}$ \\
\hline CuS/ZnS & Hydrothermal method & Visible light & $\begin{array}{l}\mathrm{H}_{2} \text { Production, Acid-Blue } \\
\text { degradation }\end{array}$ & $\begin{array}{l}\text { (Harish et al., } \\
\text { 2017) }\end{array}$ \\
\hline $\begin{array}{l}\mathrm{SnO}_{2} \\
\text { Nanospheres }\end{array}$ & $\begin{array}{l}\text { Microwave assisted } \\
\text { Solvothermal method }\end{array}$ & Visible light & Photo-oxidation of RhB & $\begin{array}{l}\text { (Parthibavarma } \\
\text { n et al., 2018) }\end{array}$ \\
\hline CdS Nanowire & Solvothermal method & Visible light & $\begin{array}{l}\text { Degradation of methylene } \\
\text { blue and RhB }\end{array}$ & $\begin{array}{l}\text { (Ganesh et al., } \\
\text { 2017) }\end{array}$ \\
\hline $\begin{array}{l}\text { CdS } \\
\text { Nanoparticles }\end{array}$ & $\begin{array}{l}\text { Chemical precipitation } \\
\text { method }\end{array}$ & Visible light & Acid Blue-29 degradation & $\begin{array}{l}\text { (Qutub et al., } \\
\text { 2016) }\end{array}$ \\
\hline $\mathrm{Fe}_{2} \mathrm{O}_{3} / \mathrm{BiOI}$ & Hydrolysis method & Visible light & RhB degradation & $\begin{array}{l}\text { (Mehraj et al., } \\
\text { 2016) }\end{array}$ \\
\hline $\mathrm{TiO}_{2} / \mathrm{ZrO}_{2}$ & Sol-gel method & UV light & Degradation of Ponceau BS & $\begin{array}{l}\text { (Pirzada et al., } \\
\text { 2015b) }\end{array}$ \\
\hline $\mathrm{BiOBr} / \mathrm{Cd}(\mathrm{OH})_{2}$ & Chemical bath method & Visible light & RhB degradation & $\begin{array}{l}\text { (Pirzada et al., } \\
\text { 2015a) }\end{array}$ \\
\hline $\mathrm{AgBr} / \mathrm{Ag}_{2} \mathrm{CO}_{3}$ & Ion Exchange Reaction & Visible light & Degradation of Ponceau BS & $\begin{array}{l}\text { (Mehraj et al., } \\
\text { 2014) }\end{array}$ \\
\hline $\mathrm{ZnO} / \mathrm{ZrO}_{2}$ & Sol-gel method & UV light & $\begin{array}{l}\text { Acid Blue-25 degradation, } \\
\text { antibacterial activity }\end{array}$ & $\begin{array}{l}\text { (Aghabeygi and } \\
\text { Khademi- } \\
\text { Shamami, 2018) }\end{array}$ \\
\hline $\mathrm{SnO}_{2} / \mathrm{SrO}$ & Hydrothermal method & UV light & $\begin{array}{l}\text { Degradation of azo-dye, drug } \\
\text { and pesticide }\end{array}$ & $\begin{array}{c}\text { (Sultana et al., } \\
\text { 2015) }\end{array}$ \\
\hline $\mathrm{Ag}_{3} \mathrm{PO}_{4} / \mathrm{BiOBr}$ & Precipitation method & UV light & $\begin{array}{l}\text { Degradation of RhB and } \\
\text { Phenol }\end{array}$ & $\begin{array}{l}\text { (Mehraj et al., } \\
\text { 2015a) }\end{array}$ \\
\hline $\begin{array}{l}\mathrm{Fe}_{3} \mathrm{O}_{4} / \mathrm{TiO}_{2} / \mathrm{Ag} \\
\mathrm{NC}\end{array}$ & $\begin{array}{l}\text { Sol-gel, hydrothermal } \\
\text { method }\end{array}$ & Visible light & Photoreduction of ampicillin & $\begin{array}{l}\text { (Y. Zhao et al., } \\
\text { 2016) }\end{array}$ \\
\hline $\begin{array}{l}\mathrm{TiO}_{2} / \mathrm{ZnS}-\mathrm{In}_{2} \mathrm{~S}_{3} \\
\mathrm{NC}\end{array}$ & Electrospinning method & Visible light & RhB Degradation & $\begin{array}{l}\text { (C. Liu et al., } \\
\text { 2015) }\end{array}$ \\
\hline $\begin{array}{l}\mathrm{TiO}_{2-} \\
\mathrm{MWCNT} / \mathrm{Al}_{2} \mathrm{O}_{3} \\
\mathrm{NC}\end{array}$ & Sol-gel method & Visible light & $\begin{array}{l}\text { Photodegradation of Methyl } \\
\text { Orange }\end{array}$ & $\begin{array}{c}\text { (W. Zhang et al., } \\
\text { 2015) }\end{array}$ \\
\hline $\mathrm{Cu}_{2} \mathrm{O} / \mathrm{TiO}_{2}$ & Electrospinning procedure & $\begin{array}{l}\text { UV and } \\
\text { Visible light }\end{array}$ & $\begin{array}{l}\text { Photocatalysis of p-nitro } \\
\text { phenol }\end{array}$ & $\begin{array}{l}\text { (Yang et al., } \\
\text { 2010) }\end{array}$ \\
\hline $\mathrm{ZnO} / \mathrm{Zn}(\mathrm{OH}) \mathrm{F}$ & $\begin{array}{l}\text { Microfluidic Chemical } \\
\text { Method }\end{array}$ & UV light & Photodegradation of MB & $\begin{array}{l}\text { (D. Zhao et al., } \\
\text { 2016) }\end{array}$ \\
\hline $\mathrm{Ag}_{3} \mathrm{PO}_{4} / \mathrm{TiO}_{2}$ & $\begin{array}{l}\text { Electrospinning and solution } \\
\text { process }\end{array}$ & Visible light & RhB Degradation & $\begin{array}{l}\text { (Yao et al., } \\
\text { 2012) }\end{array}$ \\
\hline $\mathrm{SiO}_{2} / \mathrm{Bi}_{2} \mathrm{WO}_{6}$ & $\begin{array}{l}\text { Hydrothermal and } \\
\text { calcination method }\end{array}$ & $\begin{array}{l}\text { UV and Visible } \\
\text { light }\end{array}$ & $\begin{array}{l}\text { RhB and Ponceau BS } \\
\text { degradation }\end{array}$ & $\begin{array}{c}\text { (Liao et al., } \\
\text { 2015) }\end{array}$ \\
\hline
\end{tabular}




\begin{tabular}{|c|c|c|c|c|}
\hline $\mathrm{Ce}-\mathrm{ZrO}_{2} / \mathrm{SiO}_{2}$ & $\begin{array}{l}\text { Template assisted thermal } \\
\text { method }\end{array}$ & UV light & Methylene blue degradation & $\begin{array}{l}\text { (Schneider and } \\
\text { Naumann, } \\
\text { 2014) }\end{array}$ \\
\hline $\mathrm{SiO}_{2} / \mathrm{CuO}$ & $\begin{array}{l}\text { Electrospinning soaking and } \\
\text { calcination method }\end{array}$ & $\begin{array}{l}\text { UV and Visible } \\
\text { light }\end{array}$ & $\begin{array}{l}\text { Degradation of RhB and } \\
\text { Phenol }\end{array}$ & (Hu et al., 2015) \\
\hline $\mathrm{TiO}_{2} / \mathrm{ZnFe}_{2} \mathrm{O}_{4}$ & Hydrothermal method & $\begin{array}{l}\text { UV and Visible } \\
\text { light }\end{array}$ & $\begin{array}{l}\text { Photocatalytic and photo- } \\
\text { electrochemical activity }\end{array}$ & $\begin{array}{l}\text { (Wang et al., } \\
\text { 2013) }\end{array}$ \\
\hline $\mathrm{BiOCl} / \mathrm{Bi}_{4} \mathrm{Ti}_{3} \mathrm{O}_{12}$ & Solvothermal method & Visible light & $\begin{array}{l}\text { Photodegradation of methyl } \\
\text { orange and p-nitrophenol }\end{array}$ & $\begin{array}{c}\text { (M. Zhang et al., } \\
\text { 2015) }\end{array}$ \\
\hline $\mathrm{CO}_{3} \mathrm{O}_{4} / \mathrm{Fe}_{2} \mathrm{O}_{3}$ & Low-Temperature Method & UV Light & $\begin{array}{l}\text { Degradation of Acridine } \\
\text { Orange and Brilliant Cresyl } \\
\text { Blue }\end{array}$ & $\begin{array}{c}\text { (M. Zhang et al., } \\
\text { 2015) }\end{array}$ \\
\hline $\mathrm{TiO}_{2} / \mathrm{WO}_{3}$ & Hydrothermal method & Visible light & Degradation of diclofenac & $\begin{array}{l}\text { (Mugunthan et } \\
\text { al., 2018) }\end{array}$ \\
\hline $\mathrm{SnO}_{2}-\alpha-\mathrm{Fe}_{2} \mathrm{O}_{3}$ & Grinding method & Visible light & Degradation of Phenol & $\begin{array}{c}\text { (Devi and } \\
\text { Shyamala, 2018) }\end{array}$ \\
\hline $\mathrm{Ag} / \mathrm{BiVO}_{4}$ & $\begin{array}{l}\text { Microwave hydrothermal } \\
\text { method }\end{array}$ & Visible light & $\begin{array}{l}\text { Degradation of bisphenol } A \text {, } \\
\text { RhB, MB }\end{array}$ & $\begin{array}{l}\text { (Regmi et al., } \\
\text { 2018a) }\end{array}$ \\
\hline $\mathrm{Au} / \mathrm{CeO}_{2}$ & $\begin{array}{l}\text { Ligand-assisted } \\
\text { impregnation }\end{array}$ & Visible light & $\begin{array}{l}\text { Reduction of nitrobenzene, } \\
\text { Acetophenone, }\end{array}$ & (Ke et al., 2013) \\
\hline $\mathrm{Au} / \mathrm{ZrO}_{2}$ & $\begin{array}{ll}\text { Ligand } & \text { assisted } \\
\text { impregnation } & \end{array}$ & Visible light & $\begin{array}{l}\text { Reduction of Nitro aromatic } \\
\text { compounds }\end{array}$ & $\begin{array}{l}\text { (Zhu et al., } \\
\text { 2010) }\end{array}$ \\
\hline $\begin{array}{l}\mathrm{WO}_{3} / \mathrm{BiVO}_{4} / \mathrm{TiO}_{2} \\
\mathrm{NC}\end{array}$ & $\begin{array}{l}\text { hydrothermal, spin coating } \\
\text { and electrodeposition } \\
\text { methods }\end{array}$ & Visible light & $\begin{array}{l}\text { Photoelectrochemical water } \\
\text { splitting }\end{array}$ & $\begin{array}{l}\text { (Kalanur et al., } \\
\text { 2017) }\end{array}$ \\
\hline $\begin{array}{l}\mathrm{Ag}_{2} \mathrm{~S} / \mathrm{NiO}-\mathrm{ZnO} \\
\mathrm{NC}\end{array}$ & Precipitation method & Visible light & $\begin{array}{l}\text { Degradation of RhB, Acetone } \\
\text { sensing }\end{array}$ & $\begin{array}{c}\text { (Shafi et al., } \\
\text { 2019) }\end{array}$ \\
\hline
\end{tabular}

*NM $=$ Nanomaterials, UV $=$ Ultraviolet. $\mathrm{RhB}=$ Rhodamine $\mathrm{B}, \mathrm{NC}=$ Nanocomposite

\section{Nanosensors in trace contaminant detection in environmental mediums}

A nanosensor is a miniaturized device, which converts a chemical interaction into electrically useful signal. The information obtained from the chemical interaction quantifies the composition and detects the presence or absence of particular element or ion, activity, concentration etc (Shafi et al., 2019). Excessive use of natural resources and environmental pollution has received a paramount attention and its monitoring is of prime concern for human welfare. Sensors for detection of hazardous pollutants, ecological VOCs and trace impurities in environment are indispensible for sustainable development of environment and human welfare (Hernandez-Vargas et al., 2018; Jalal et al., 2018). Recently, tremendous efforts have presented a leap-forward in the development of metal oxide nanosensors which are proving efficient materials in the remediation of the environment. Metal oxide nanostructures are peculiar materials which have intrigued the whole scientific community by 
their novel features. The remarkable features of these tiny structures are assessed for detection and quantification of several hazardous gases, poisonous chemicals and biochemicals in the environment. Metal oxide nanostructures in the form of chemical, gas, biological, optical and humidity sensors have been extensively researched to detect the ecological pollutants and VOCs present in the environment (Das et al., 2015; Z. Li et al., 2019; Solanki et al., 2011).

Till now, several sensing techniques have been developed, but due to their high cost, insensitivity and time-consuming nature, those techniques are unsuitable for environmental pollutant detection. Therefore, a facile and low-cost method of environmental remediation was based on fabrication of metal oxide (MO) nano-sensors. MO nano-sensors are easy to prepare, economical and efficient in function and operation. Although, metal oxide nanostructures exhibit excellent sensing properties, but the sensitivity and selectivity has always been a question of debate. To improve the stability, sensitivity and response time of these MO nanosensors, they are combined with other organic counterparts to form a nanocomposite which not only improves stability but also exhibit synergistic effect for desirable sensing application (Ganie et al., 2021; Shang et al., 2019). From recent past, several efforts have been devoted to manufacture MO nanocomposites with graphene (RGOMO) for highly effective, sensitive and selective sensing performance. Graphene, due its fascinating properties are deal material for trace quantity detection (Wang et al., 2016). The sensing property of metal oxide decorated carbon materials are due to intriguing structural features which could provide large number of active sites on the surface, enhance the surface interaction of nanosensor with the target gas and thereby increases the sensing performance of the nanomaterial. 
Metal oxide gas sensors have been introduced in 1960s; When Seiyama et al., (1962) reported the operation of gas sensors on basis of chemical interaction or resistance changes of the MOS layer and the analyte gas molecule. Since then, several MO nano architectures in form of nanotubes, nanofibers, nanoflowers, nanorods, nanospheres, nanosheets, nanowires and nanodots have been fabricated for gas sensor application. Cretu et al., (2016) developed hydrogen gas sensor based on zinc doped copper oxide nanomaterials which exhibited excellent sensor response with faster response time and good sensitivity. Sankar ganesh et al., (2017) investigated the effect of $\mathrm{Al}$ doping into the $\mathrm{ZnO}$ matrix for detection of ammonia and found that $\mathrm{Al}$ doped $\mathrm{ZnO}$ turns out to be suitable sensor for the quantification of trace amount of ammonia. It was also pointed out that activity of the fabricated sensor was improved due to catalytic effect which henceforth, demonstrated a strong link between gas sensing and heterogeneous catalysis. Han et al., (2016) reported the fabrication of $\mathrm{NO}_{2}$ sensor using synergistic effects of $\mathrm{ZnO} / \mathrm{PMMA}$ and $\mathrm{CuPc} /$ pentacene heterojunctions. The fabricated OFET sensors showed good sensitivity and lower detection limit. This study demonstrates that the synergistic effect of dielectrics and organic semiconductors can be utilized to develop reliable and accurate gas sensors. Li et al., (2017) synthesized formaldehyde sensor by using facile hydrothermal method. The formaldehyde sensor based on $\mathrm{SnO}_{2}$ microspheres showed high sensitivity, good stability and response recovery at $200^{\circ} \mathrm{C}$ temperature.

Chemiresistive gas sensors based on MO nanostructures have been remarkably used for detection of volatile organic compounds (VOCs). The VOCs are widely used in industries and household products, causing deleterious effects on human health even in ppm concentrations. The detection of VOCs such as acetone, methanol, $\mathrm{NH}_{3}, \mathrm{HCHO}$, benzene and toluene is necessary due to their long-term health effects (Moseley, 2017). Chemiresistive gas sensors represent a major class of gas sensors, whose electrical resistance changes on exposure to target analyte (either oxidising or reducing) and showed fast response and 
recovery times towards several VOCs (methanol, toluene, acetone, propanol etc.). Joseph et al., (2004) reported the crosslinking of gold and platinum nanoparticles with nonanedithiol which showed $\mathrm{CO}$ and $\mathrm{NH}_{3}$ detection up to 500 ppm concentration. Feng et al., (2019) developed a methanol sensor based on $\mathrm{NiO}$ fibres which can detect methanol up to $500 \mathrm{ppm}$ level. The sensor possesses high selectivity, high response time and operates at room temperature. The sensing performance of VOCs can be explained on basis of ionosorption model. When a metal oxide nanostructure is exposed to air, oxygen molecules are adsorbed on surface of metal oxide. The adsorption of oxygen molecules is facilitated by cationic vacancies on metal oxide.

$\mathrm{O}_{2(\mathrm{~g})}+2 \mathrm{e}^{-} \longrightarrow 2 \mathrm{O}_{(\mathrm{ads})}^{-}+2 \mathrm{~h}^{+}$

After that, when metal oxide nano-sensor is exposed to target analyte (e.g., methanol), the methanol molecules react with ionosorbed oxygen species, to produce electrons. These electrons are returned to metal oxide, thus increasing the resistance of sensor. Thus, the operation of metal oxide nano-sensor is based on resistance change upon exposure to target analyte.

$$
\mathrm{CH}_{3} \mathrm{OH}+3 \mathrm{O}^{-} \longrightarrow \mathrm{CO}_{2}+2 \mathrm{H}_{2} \mathrm{O}+3 \mathrm{e}^{-}
$$

Another recently developed cost effective and facile gas sensor based on cellulose fibres present within paper by exploiting intrinsic hygroscopic properties of cellulose fibres. Cellulose fibres within paper inherently contains substantial amount of moisture enabling the use of wet chemical method for sensing without manually adding water to the substrate. The sensor exhibits high sensitivity to water soluble gases with fast and reversible response. The sensor shows comparable or better performance than most commercial ammonia sensors. This sensor can be integrated into food packaging's to monitor freshness and to reduce food waste or can be implemented into near field communication to tag functions as wireless, 
battery-less gas sensors that can be interrogated with smartphones. Moreover, this sensor has specifically shown higher sensitivity, lower detection limits and rapid response time for ammonia detection as it is highly soluble with high humidity, $\mathrm{RH}>60 \%$ (Chiu et al., 2019).

\subsection{Electrochemical Sensors for detection of refractory organics}

Contamination of soil and water bodies by uncontrolled disposal of solid and liquid waste drawn from innumerable sources like waste-water discharges from oil field, different types of industrial waste from chemical, textiles, petrochemical, food and beverages industries and hospital discharges have shown negative impact on the present ecosystem. These wastes largely contain inorganic pollutants like excessive discharges of metal ions and organic pollutants like phenol, benzene, alkanes, polycyclic aromatic hydrocarbons (PAHs) and many more pollutants. The constituent analysis, quantification, detection and determination play a pivotal role in assessing and close monitoring of the toxic elements and are of prime importance as they supposedly causes severe ailments and diseases resulting in damaging of lungs, kidneys, liver, thus interfering body metabolism.

In order to determine and detect these toxic pollutants, various techniques like HPLC, AAS, FID, liquid chromatography, colorimetry, isotopic-dilution mass spectrometry, chemiluminescence, and devices based on varieties of electro-analytical techniques mainly potentiometry, differential pulse voltammetry have been used so far. However, eelectrochemical techniques are very efficient for real time detection of pollutants as well as for addressing serious environmental problems (Jang et al., 2018). The application of electrochemical/chemical sensor is based on the deduction of chemical composition of surrounding environment, giving reliable information about the environmental health. The main feature of the electrochemical sensors is quick and reversible response without the perturbation of sample. Chemical sensors based on nanostructured semiconductor materials 
for the detection of refractory organics, such as nitrophenol, hydrazine and phenyl hydrazine, have been recognized as a very promising approach, which has attracted intensive attention from both academic and industrial fields in the past few years. These electrochemical techniques have several advantages over other method because of their remarkable sensitivity, portability and lower cost. Electrochemical sensors fall into various categories like voltammetric, potentiometric and amperometric sensors. Besides these kinds of sensors, SWASV (Square wave anodic stripping voltammetry), DPASV (Differential pulse anodic stripping voltammetry) techniques are very fast, highly reliable, most accurate and highly sensitive. These evolved techniques are important for analysing real samples for real time detection (Veerakumar et al., 2015).

\subsection{Detection of various solvents and toxic organic pollutants}

The detection of various toxic solvents, drugs or other interfering materials are most easily done by using various modes of electrochemical techniques like cyclic voltammetry, amperometry, linear sweep voltammetry and differential pulse voltammetry. These techniques are most widely exploited for the detection of toxic solvents in the environment, biosensing of glucose, dopamine, and ascorbic acid along with many drugs like acetophenone, aspirin, ciprofloxacin, sulfamaxole etc. These techniques proved to be highly sensitive and reliable by utilising varieties of modified nanoparticles and nanocomposites ranging from metal oxides to different carbon nanomaterial including graphene oxide, carbon nanotubes, activated carbon platforms and conducting polymers like (PANI, Ppy, PTh). The nanocomposites based electrochemical sensors have shown excellent stability, high specific surface area, high conductivity, high thermal stability, and increased electron conductivity and has been extensively investigated for the detection and quantification of various hazardous and toxic solvents from the environment (Sayfa et al., 2019). Considering the ideal 
parameters into view, various metallic, bimetallic, conducting polymers based or derived nanocomposites have been investigated and utilised as chemical sensors. The detection of the target analyte depends on many factors like electro-activity of the composite catalyst, types of electrode, electrolytic solution and working conditions (temperature, concentration and $\mathrm{pH}$ ). Varieties of nanocomposites have been synthesized for obtaining the best suitable electrocatalyst in order to analyse and detect the toxic contaminants. Qin et al., (2014) has reported zircon-based carbon paste electrode as amperometric sensor for determination of phenol using phosphate buffer as electrolyte. The fabricated sensor was found to show efficient electroanalytic response towards detection of phenol with $9 \mu \mathrm{M}$ LOD at an S/N ratio of 3. Another group of researchers has developed hybrid materials based on single walled carbon nanotubes (SWCNT) and poly (3,4-ethylenedioxythiophene). The screen-printed electrodes (SPE) has been modified using these nanocomposites and has been utilized for simultaneous determination of phenol and chlorophenol derivatives. The modified SPE has shown better response than enzymatic and non-enzymatic sensor with much wider and dynamic linear range of detection. It can most widely be used as disposable electrochemical sensor for determination of trace level of pollutants and toxic compounds in environment and biological real samples. Rehman et al., (2011) reported the hydrothermal fabrication of $\mathrm{CuO}$ co-doped $\mathrm{ZnO}$ nanostructured material for detection of ammonia sensing as target analyte using silver electrodes. The developed electrodes displayed good sensitivity, stability, and reproducibility with corresponding detection limits of $8.9 \mu \mathrm{M}$ with short response time. Another group of researchers fabricated $\mathrm{ZnO}$ nanosheets based screen printed electrodes by electrodeposition method and studied the electrochemical responses for the detection of phenol and o-cresol by using cyclic voltammetry and linear sweep voltammetry. The fabricated sensor has shown better electro-catalytic oxidation of phenol and o-cresol in real wastewater sample. Moreover, the sensor has shown 4.1nM and 5.5nM detection limits for 
phenol and o-cresol respectively, for wide linear range of $0.01 \mu \mathrm{M}$ to $50 \mu \mathrm{M}$ (Liu et al., 2016). Nithya, (2015) has reported the determination of ascorbic acid using zinc decorated graphene oxide based on glassy carbon electrode using differential pulse voltammetry. The nanocomposites have shown high surface area with efficient electrocatalytic response in the wide linear range (1 $\mu \mathrm{M}$ to $1000 \mu \mathrm{M})$ having sensitivity and detection limit of 0.178 $\mu \mathrm{A} / \mu \mathrm{M} / \mathrm{cm}^{2}$ and $0.01 \mu \mathrm{M}$ respectively. In this study the comparison of colorimetry and voltammetry has also been shown, indicating that voltammetric sensors produce more reproducible results. Since early development on glucose detection was based on enzymatic biosensor which certainly suffers from various operating drawbacks. In order to overcome these limitations, various nanostructured materials (non-enzymatic chemical sensor) have been used as glucose sensors (Al-mokaram et al., 2017). Recent studies have been focussed on developing peptide-based hybrid compounds using metallic electrode materials mainly gold, as biosensors. Bianchi et al., (2014) has reported peptide based non- enzymatic biosensor for estimating ammonia and urea oxidation by using peptide microstructure onto the thiolate gold electrodes. The developed assemblies possess different functional group which considerably interacts with target species via cationic-П-receptors and hydrogen bonding. The biosensor under optimal conditions has shown excellent catalytic response for both ammonia and urea within concentration range of $0.1 \mathrm{mM}$ to $1 \mathrm{mM}$. The calculated sensitivity was found to be 2.83 and $81.3 \mu \mathrm{A} / \mathrm{mM} / \mathrm{cm}^{2}$ for ammonia and urea respectively at applied potential of $+0.4 \mathrm{~V}$ vs SCE suggesting it as a highly sensitive sensor capable of detecting ammonia even below physiological levels of 1-100 mM.

\subsection{Early discrimination of heavy metal ions}

Among the various techniques used for heavy metal ions detection, the most effective and facile among them are colorimetry and cyclic voltammetry. Both techniques offer simple and 
facile procedure for the determination of metal ions and various pharmaceutical products. Colorimetry uses masking agent like EDTA, glutathione, and imidazole for simultaneous determination of metal ions. Zhang et al., (2012) has developed peptide modified gold nanoparticles(P-AuNPs) for determination and quantification of metal ions like $\mathrm{Cd}^{2+}, \mathrm{Ni}^{2+}$ and $\mathrm{Co}^{2+}$ in wastewater samples The tests were carried out by monitoring the change in colouration of the probe upon mixing with metal ions solution. The method shows relatively good selectivity for $\mathrm{Cd}^{2+}, \mathrm{Ni}^{2+}$ and $\mathrm{Co}^{2+}$ over other metal ions. $\mathrm{Cd}^{2+}$ shows the most obvious colour change over $\mathrm{Ni}^{2+}$ and $\mathrm{Co}^{2+}$ while using EDTA (masking $\mathrm{Co}^{2+}$ ), glutathione (masking $\mathrm{Cd}^{2+}$ ), and imidazole (masking $\mathrm{Ni}^{2+}$ ) as masking agents. This novel gold (P-AuNPs) based probe offers several advantages like simplicity of preparation and rapid detection of heavy metal ions with high sensitivity. Different gold nanoparticles are investigated in colorimetric determination due to their colour change attributing properties. Gold nanoparticles modified with multifunctional graphene prepared by one pot redox reaction have been investigated for colorimetric determination of $\mathrm{Hg}^{2+}$ in water samples, exhibiting detection limits up to 0.16 nM (Yan et al., 2014). Mehta et al., (2013) has demonstrated the real water sample analysis for detection of copper $\left(\mathrm{Cu}^{2+}\right)$ ions using dopamine dithiocarbamate-functionalized gold nanoparticles. The decorated gold nanoparticles exhibit characteristic colour change with lower detection limit of $14.9 \mu \mathrm{M}$ and linear range of 1-10 mM. Since, metal ions are most harmful toxics pollutants present in water and soil bodies, but on the other hand, these metal ions are essential for normal functioning of human body. However, the presence of metal ions beyond threshold level can cause severe health problems which can have significant negative impact on human welfare (Li et al., 2018).

Z. Guo et al., (2017) has reported the utilisation of DPASV technique for determination of $\mathrm{Cd}, \mathrm{Cu}$, and $\mathrm{Pb}$ using chitosan-poly-L-lysine nanocomposites modified glassy carbon electrode (GCE). The detection limits for $\mathrm{Cd}, \mathrm{Cu}$, and $\mathrm{Pb}$ were found to be $0.01 \mu \mathrm{g} / \mathrm{L}, 0.02$ 
$\mu \mathrm{g} / \mathrm{L}$ and $0.02 \mu \mathrm{g} / \mathrm{L}$ respectively. Veerakumar et al., (2016) has analysed the electrochemical detection of $\mathrm{Cd}, \mathrm{Pb}, \mathrm{Cu}$, and $\mathrm{Hg}$ using palladium nanoparticles supported on porous activated carbon. The porous activated carbon nanoparticles were synthesized by green synthesis from biomass feedstock. The Pd/PAC modified GCE exhibit excellent results for simultaneous determination of metal ions with wide linear range of concentration, high sensitivity and low detection limits. Another group has investigated the $\mathrm{Ce}-\mathrm{Zr}$ oxide nanospheres for electrochemical determination of $\mathrm{Hg}, \mathrm{Cd}, \mathrm{Cu}$ and $\mathrm{Zn}$ by using SWASV technique. The efficient redox behaviour of nanospheres has resulted in the quantification of metal ions with lower LOD and sensitivity of $0.006 \mu \mathrm{M}$ and $1662.02 \mu \mathrm{M} / \mathrm{cm}^{2}$ respectively (Li et al., 2018). Ni nanoparticles decorated on activated carbons have been used for electrochemical detection of $\mathrm{Hg}$ ions by using GCE as working in the cyclic voltammetric experiment. The fabricated sensor has shown selective and sensitive detection of metal ions with detection limits up to 10 nM (Veerakumar et al., 2015).

Moreover, the versatile applications of MOF in different sensing application have opened a new gateway in electrochemical detection by increasing the electrocatalytic activity of the developed nanoparticles by substantial amount. Zhao et al., (2019) reported a modified MOF by using a conducting polymer (PANI) as self-doped polyaniline (SPAN) modified metal organic framework (SPAN@UIO-66-NH2). The developed materials have shown excellent electrical conductivity with rapid electron transfer rate for detection of $\mathrm{Cd}^{2+}$ by using SWASV technique. The MOF based electrochemical sensor has shown faster response time with corresponding detection limit of $0.17 \mathrm{ug} / \mathrm{L}$ in real sample analysis. This suggests the utilisation of fabricated MOF based electrochemical sensor in real water sample analysis and urine samples for detection of cadmium ions. Another group developed a MOF based on zeolite materials and examined it for detection of $\mathrm{Pb}$ (II) ions using DPASV techniques. The electrocatalyst has shown synergistic features of MOFs and zeolites such as high surface area, 
crystallinity, better thermal and chemical stability and highly ordered structure. The combined properties of both have led to the development of efficient electrochemical sensor for selective detection of lead ions in aqueous solution. Moreover, the electrochemical response of the sensor shows lower detection limit of $\mathrm{Pb}$ ions (4.12-12.50 ppb) with optimized reaction parameters and wide linear range from 12 ppb to $100 \mathrm{ppb}$ (Khieu et al., 2018).

Other toxic metal ions like $\mathrm{Cd}, \mathrm{As}, \mathrm{Pd}, \mathrm{Co}, \mathrm{Ag}, \mathrm{Zn}, \mathrm{Cr}$ and $\mathrm{Ni}$ are also being monitored in the environment by using newly developed techniques. Zhou et al., (2016) has reported DNA based $\mathrm{MoS}_{2} / \mathrm{Au}$ hybrid FET sensor for ultrasensitive detection of $\mathrm{Hg}$ ions in aqueous solution. The sensor performance was investigated using specific DNA as the capture probe for the label free detection by monitoring the electrical characteristics of FET device. This sensor shows a rapid response to $\mathrm{Hg}$ ions with ultra-low detection limits of $0.1 \mathrm{nM}$, which was found to be lower than maximum limits for $\mathrm{Hg}$ ions in drinking water $(9.9 \mathrm{nM})$ as recommended by USEPA, along with high sensitivity to $\mathrm{Hg}$ ions as compared with other ions like $\mathrm{As}, \mathrm{Cd}$, and $\mathrm{Pb}$. The applications of several electrochemical techniques in the detection of trace amounts of pollutants in the environment have been reviewed and are shown in Table 2.

Table. 2. Application of various nanomaterial based electrochemical sensors in detection and quantification of Hazardous pollutants.

\begin{tabular}{lccccc}
\hline $\begin{array}{l}\text { Nanostructured } \\
\text { materials }\end{array}$ & $\begin{array}{c}\text { Electrochemical } \\
\text { techniques }\end{array}$ & Target analyte & $\begin{array}{c}\text { Limit of } \\
\text { detection } \\
(\mu \mathrm{M})\end{array}$ & $\begin{array}{c}\text { Concentration } \\
\text { linear range } \\
(\mu \mathrm{M})\end{array}$ & $\begin{array}{c}\text { Sensitivity } \\
\left(\mu \mathrm{A} / \mu \mathrm{M} / \mathrm{cm}^{2}\right)\end{array}$ \\
\hline $\mathrm{Ni}(\mathrm{II})$-based & Square wave & $\mathrm{Pb}^{2+}$ & 0.508 & $0.5-6.0$ & - \\
$\begin{array}{l}\text { metal-organic } \\
\text { frameworks }\end{array}$ & $\begin{array}{c}\text { anodic stripping } \\
\text { voltammetry }\end{array}$ & & & \\
\end{tabular}




\begin{tabular}{|c|c|c|c|c|c|c|}
\hline $\begin{array}{l}\text { Graphene } \\
\text { Oxide/Cobalt }\end{array}$ & Amperometry & Insulin & $0.12 \times 10^{-9}$ & 0.00046 to 0.1 & 686.6 & $\begin{array}{c}\text { (Razmi et al., } \\
\text { 2019) }\end{array}$ \\
\hline \multicolumn{7}{|l|}{ Oxide } \\
\hline \multicolumn{7}{|l|}{ Nanocomposite } \\
\hline$\gamma-\mathrm{Fe}_{2} \mathrm{O}_{3}$ & Stripping & $\mathrm{Pb}^{2+}$ & - & 0.0001 to 0.001 & 0.19782 & (S. Li et al., \\
\hline nanoflower & voltammetry & & & & & 2016) \\
\hline Acetyl- & Amperometry & Paraoxon & 0.0007 & 0.005 to 1.0 & - & (Lang et al., \\
\hline cholinesterase & & & & & & 2016) \\
\hline biosensor based & & Dimethoate & 0.0039 & 0.005 to 1.0 & - & \\
\hline \multicolumn{7}{|l|}{ on gold NPs } \\
\hline 3D Copper Foam- & Amperometry & Glucose & 1000 & 0 to 1000 & $2.09 \times 10^{3}$ & (Liu et al., \\
\hline Supported & & & & & & 2018) \\
\hline \multicolumn{7}{|l|}{$\mathrm{CuCO}_{2} \mathrm{O}_{4}$} \\
\hline \multicolumn{7}{|l|}{ Nanosheet } \\
\hline Au-Pt alloy & Amperometry & Methanol & 100 & 1000-11000 & 43 & (Guo et al., \\
\hline nanocatalysts & & & & & & 2014) \\
\hline CuO-NPs/3DGR & Differential Pulse & Malathion & $1 \times 10^{-5}$ & $3 \times 10^{-5}-0.0015$ & - & (Xie et al., \\
\hline & Voltammetry & & & & & 2018) \\
\hline Core-Shell $\mathrm{CeO}_{2}$ & Gas sensor & $\mathrm{NH}_{3}$ gas sensor & - & 6.5 to $50 \mathrm{ppm}$ & - & (Wang et al., \\
\hline nanoparticles@c & & & & & & 2014) \\
\hline ross-linked PANI & & & & & & \\
\hline
\end{tabular}

4. Nanoadsorbents and Nanocatalysts for wastewater and soil remediation: Added benefits and challenge for nanoremediation

\subsection{Water, groundwater and wastewater treatment and remediation}

With the advancement in horticultural, agricultural, industrial and urban activities, the quality of ground water is deteriorated and the level of pollution is increasing day by day (Belal and El-Ramady, 2016). The seepage of numerous inorganic and organic pollutants above their permissible limits into the groundwater has deleterious effects on its quality, standard and 
composition. Nowadays natural water bodies have been used as dumping sites which has reduced the quality of ground water. Excessive use of fertilisers, pesticides and weedicides has posed a serious threat to the quality and composition of ground water (Andreozzi et al., 1999; Sharma and Bhattacharya, 2017). Furthermore, water has been enriched by most harmful chemicals such as organochlorines, organophosphorus, heavy metals, and various carcinogenic agents. Prolonged persistence of organic chemicals in water has resulted in bioaccumulation of these pollutants which has severe and hazardous effects on human beings. It has been reported that lindane (hexachlorocyclohexane), an organopesticide has bioaccumulated into the human food chain disturbing the normal functioning of endocrine system and causing cancer in humans (Jayaraj et al., 2016). Cultural Eutrophication of water bodies has become a serious problem and has shown a range of devastating effects. One major effect is algal bloom, which can deplete dissolved oxygen content of the water bodies, affecting marine life as shown in Figure 6. Cultural eutrophication is not only detrimental to marine life but it can affect the terrestrial life as well due to the harmful toxins released by algae such as anatoxin-a, domoic acid, brevotoxin, saxitoxin, microcystin, geosmin (Paerl et al., 2018).

Nanoremediation as compared to other remediation techniques proved to be an efficient technique for groundwater decontamination. Nanoremediation has been applied for the remediation of variety of contaminants present in water such as chlorinated compounds, heavy metals, hydrocarbons or organic compounds, pesticides and inorganic ions (X. Liu et al., 2019; Y. Liu et al., 2019; Rajan, 2011; Teow and Mohammad, 2019; Zhang and Liu, 2020). The application of in situ nanoremediation in Water, groundwater and wastewater treatment relies on the use of nanoadsorbents, membrane systems based on nanocomposites and nanocatalysts. The efficient adsorption properties and excellent membrane permeability of nanomaterials allows rapid waste-water treatment and complete removal of organic 
pollutants, heavy metals and antibiotic-resistance bacteria. Photocatalytic nanomaterials can play a potential role in degrading harmful algal blooms in water hence maintain the natural quality of water.

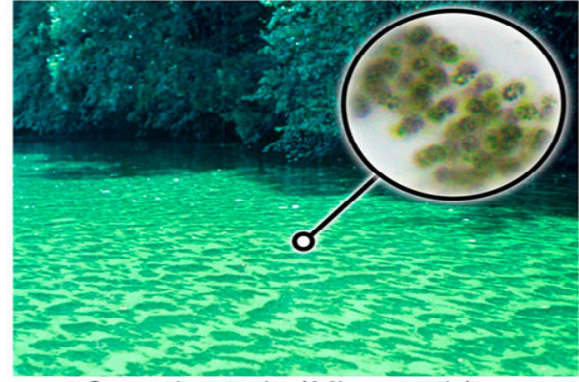

Cyanobacteria (Microcystis)

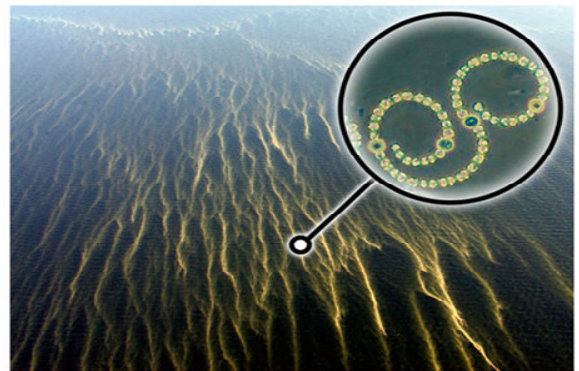

Cyanobacteria (Nodularia)



Dinoflagellates (Prorocentrum)

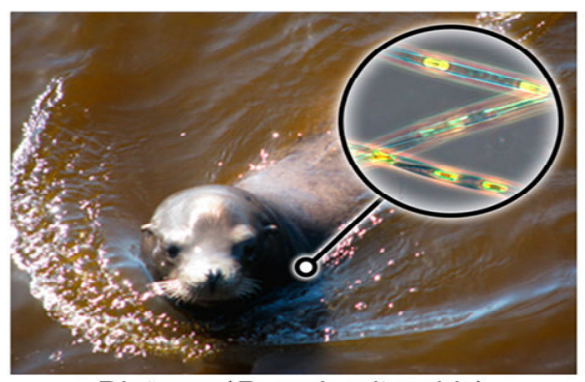

Diatoms (Pseudo-nitzschia)



Chlorophytes (filamentous green algae)

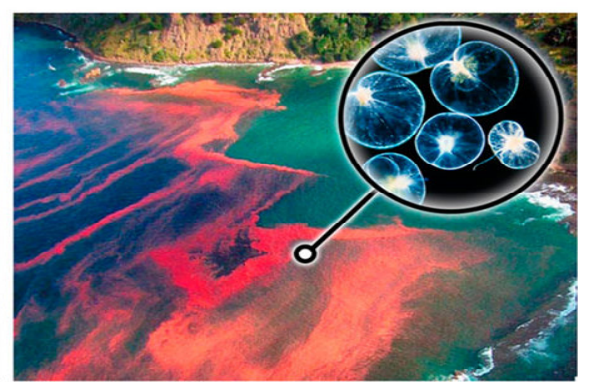

Dinoflagellates (Noctiluca)

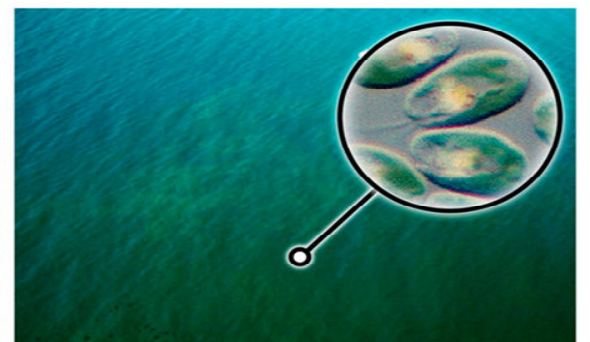

Cryptophytes (Cryptomonads)

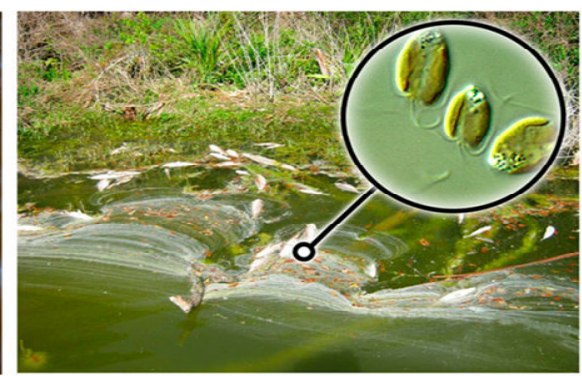

Prymnesiophytes (Prymnesium parvum)

Figure 6. Harmful bloom formation depicting cultural eutrophication of water along the fresh water to marine continuum, Reproduced from (Paerl et al., 2018) 
It has been reported that $\mathrm{Ni}$ doped $\mathrm{BiVO}_{4}$ nanocomposite can cause the inactivation of algae under visible light irradiation and retard the formation and proliferation of algal bloom (Regmi et al., 2017b). Co-doped $\mathrm{BiVO}_{4}$ have been utilized for the effective degradation of malachite green and has also shown efficient activity towards inactivation of green tides caused by the prelevance of Escherichia coli and chlamydomonas pulsatilla in wastewater (Regmi et al., 2017a). Moreover, the efficiency of $\mathrm{Ag}-\mathrm{TiO}_{2}$ and $\mathrm{MoS}{ }_{2} / \mathrm{Bi}_{2} \mathrm{WO}_{6}$ heterostructures has been studied for the elimination of blooms and detoxification of pollutants in wastewater. The application of integrated nano-biotechnique by utilising $\mathrm{Pd} / \mathrm{Fe}^{0}$ bimetallic nanoparticle in complete degradation of recalcitrant environmental pollutant lindane (hexachlorocyclohexane) has also been reported in literature (Regmi et al., 2018a).

The usefulness of photocatalysis in disintegration of harmful recalcitrant micro-organisms (bacteria, virus, fungi and protozoa) can be explained on basis of generation of highly reactive radicals which can degrade these micro pollutants present in water. Several mechanistic pathways for the inactivation and degradation of pollutants in water have been reported in literature. The main step in all the pathways involves the reduction of molecular oxygen $\left(\mathrm{O}_{2}\right)$ by the nanomaterials, thereby generating reactive oxygen species (ROS), which induce a type of stress in the normal functioning of the cell as shown in Figure 7. The cell integrity and hence the metabolism of the cell got disrupted by oxidative damage of its components which ultimately leads to inactivation or sometimes death of cell (Regmi et al., 2018b). 


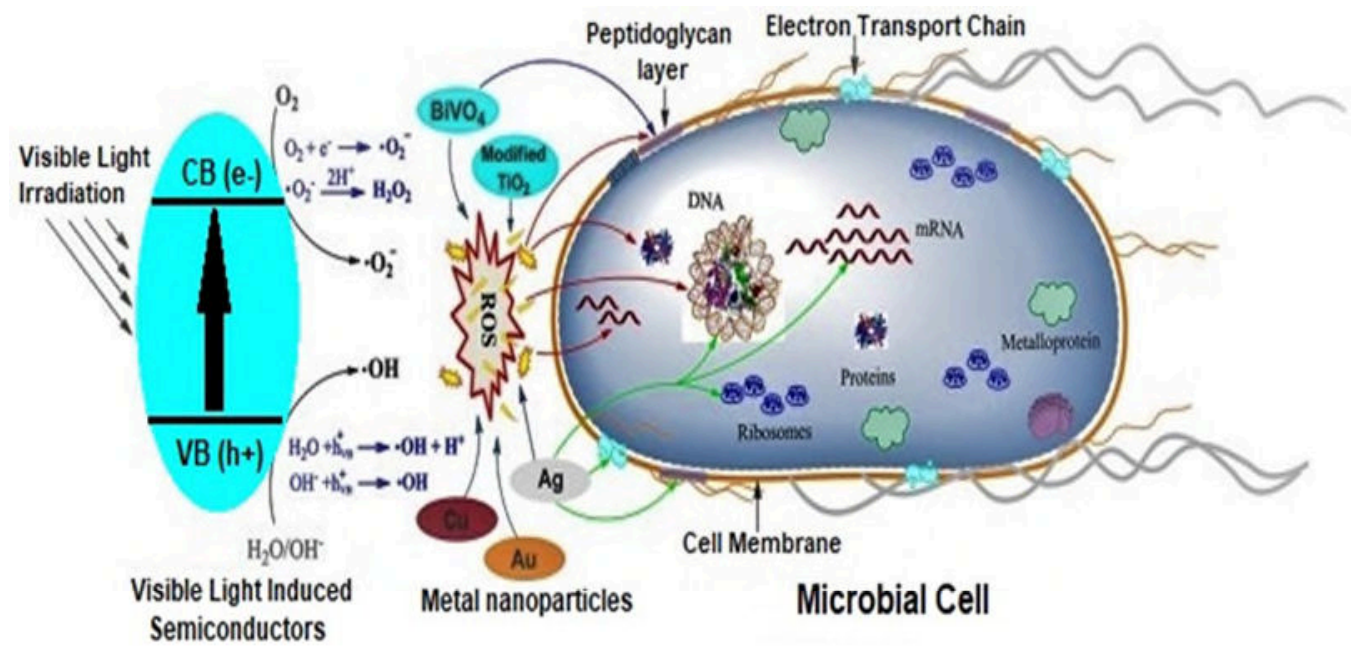

Figure 7. Pictorial mechanism of bacterial inactivation by nanomaterials to remediate wastewater, ROS generation and subsequent degradation of peptidoglycan layer of the microbial cell have been labelled, Reproduced with permission from (Regmi et al., 2018b)

The application of nano zero valent iron (nZVI) and carbon nanotubes in environment cleanup such as decontamination of groundwater, removal of organochlorines, heavy metals such as arsenic and chromium, pesticides (DDT, Lindane) and inorganic anions has shown remarkable and promising future (Lu et al., 2016). The key features favouring nZVI and carbon nanotubes include low standard reduction potential, high mobility, high reactivity and flexibility. In contaminated water, nZVI are supposed to change from $\mathrm{Fe}^{0}$ to $\mathrm{Fe}^{2+}$ and then further oxidative transformation to $\mathrm{Fe}^{3+}$, thereby reduce inorganic and organic pollutants readily (Bonaiti et al., 2017).

Carbon nanotubes are considered as efficient adsorbents because of their potential adsorption properties and ability to attach a variety of functional groups. Several researchers have investigated the adsorption behaviour of SWCNT and MWCNT for transforming organics eluted in wastewater and activated sludge (Gupta et al., 2015). Carbon nanotubes are utilized for the removal of heavy metals, harmful chemical compounds, inorganic wastes and volatile organic compounds. The adsorption activity of the carbon nanotubes can be further modified 
by surface modification techniques such as metal ions grafting, acid treatment and surface impregnation with reactive moieties (Anjum et al., 2019). The modified carbon nanotubes with metal oxides like $\mathrm{MnO}_{2}, \mathrm{Al}_{2} \mathrm{O}_{3}$ and $\mathrm{Fe}_{2} \mathrm{O}_{3}$ shows promising and efficient results for pollutant degradation and heavy metals removal from the wastewater (Khajeh et al., 2013).

The vast structural diversity of carbon-based materials combined with large surface area and hollow layered structure and high adsorption capacity has made them promising materials for wastewater decontamination (Smith and Rodrigues, 2015). Carbon based nanomaterials are efficiently used as nanoadsorbents for removal of different liquid or gaseous pollutants and have been the focus of contemporary research due to their peculiar mechanical and excellent electronic properties. Moreover, Carbon nanotubes can adsorb and simultaneously detoxify both organic as well as inorganic pollutants (Baby et al., 2019). From the recent past chitosan-based nanomaterials have received considerable attention in wastewater treatment because of their efficient functionality in adsorption of heavy metals, dyes and other water born pollutants. Among other carbon based materials, Graphene oxide and activated carbon has been the better candidates for water treatment owing to their high adsorption capability, better compatibility and excellent selectivity for a range of pollutants (Wu et al., 2019).

Various wastewater treatment methods have been described in literature, among them adsorption and photocatalytic degradation are most facile techniques which are preferred over other methods because of their cost-effectiveness and environmental friendly approach (Grassi et al., 2012; Suri et al., 1999). In adsorption process, kinetic studies are important to deduce the amount of pollutants adsorbed on the surface of nanomaterials. Several kinetic models have been explained for adsorption mechanisms, but the most used are pseudo-first order and second order kinetic models (Babel and Agustiono Kurniawan, 2003). 
The amount of pollutant which can be adsorbed on the surface of nanoadsorbent at equilibrium $\left(\mathrm{Q}_{\mathrm{e}}\right)$ is calculated using Equation 3.

$$
\mathrm{Q}_{\mathrm{e}}=\left(\mathrm{C}_{0}-\mathrm{C}_{\mathrm{e}}\right) \mathrm{V} / \mathrm{m}
$$

Where $\mathrm{C}_{0}$ and $\mathrm{C}_{\mathrm{e}}$ are the starting and equilibrium concentrations of the pollutant respectively, Vis the volume of solution and $\mathrm{m}$ is the mass of nanoadsorbent.

Apart from organic pollutants, the persistence of lead, copper and arsenic in the water bodies above their permissible limits poses serious consequences to the human health. Researchers have developed many functionalized nanomaterials which can efficiently adsorb toxic metals through their reactive groups on the surface. It has been reported that ultrafine magnesium ferrite $\left(\mathrm{Mg}_{0.27} \mathrm{Fe}_{2.50} \mathrm{O}_{4}\right)$ nanocrystallites can adsorb both $\mathrm{As}(\mathrm{III})$ and $\mathrm{As}(\mathrm{V})$ with efficient removal capacities (Tang et al., 2013). The nanocrystallites show supermagnetic behaviour and high surface area $\left(482 \mathrm{~m}^{2} / \mathrm{g}\right)$ with the adsorption capacities of $127.4 \mathrm{mg} / \mathrm{g}$ and $83.2 \mathrm{mg} / \mathrm{g}$ for $\mathrm{As}(\mathrm{III})$ and $\mathrm{As}(\mathrm{V})$ respectively. Another group of researchers developed core-shell structure of $\mathrm{Fe}-\mathrm{Ti}$ bimetallic oxide on magnetic $\mathrm{Fe}_{3} \mathrm{O}_{4}$ and was used as nanoadsorbent for fluoride removal from drinking and wastewater (Zhang et al., 2014). The nanoadsorbent shows high adsorption capacity and super magnetic behaviour. The adsorption studies were investigated by Langmuir adsorption isotherm and adsorption capacity of $57.22 \mathrm{mg} / \mathrm{g}$ was found for fluoride removal. The separation of adsorbent in both cases can be done by magnetic methods and the adsorbents can be again used for removing the pollutants. Furthermore, the $\mathrm{Cu}(\mathrm{II})$ removal was carried out by cyclodextrin modified $\mathrm{Fe}_{3} \mathrm{O}_{4}$ via strong adsorption capacities of hydroxyl and carboxyl moieties on the carboxymethyl- $\beta$-cyclodextrin (Badruddoza et al., 2011). The adsorption kinetics follows the second-order kinetics and was dependent on $\mathrm{pH}$ and temperature. The adsorption data was fitted with Langmuir model and the adsorption capacity of $\mathrm{Cu}$ (II) removal was found to be $47.3 \mathrm{mg} / \mathrm{g}$. It has been also 
reported that nanoadsorbents shows good recyclability with $96.2 \%$ desorption efficiency. The pollutant adsorption and simultaneous removal capabilities of several nanomaterials have been reviewed and are depicted in Table 3.

Table 3. Pollutant removal capacity of various nanoadsorbents by surface adsorption

\begin{tabular}{|c|c|c|c|}
\hline Nanoadsorbents & Pollutant Adsorbed & $\begin{array}{c}\text { Removal Efficiency } \\
\left(\mathrm{mg} \mathrm{g}^{-1}\right)\end{array}$ & References \\
\hline Pristine SWCNTS & Basic Red 46 & 38.35 & (Moradi, 2013) \\
\hline Untreated SWCNTS & Reactive Red 120 & 426.67 & (Cardoso et al., 2012) \\
\hline Alkali activated MWCNTs & Methylene Blue & 399.0 & (Ma et al., 2012) \\
\hline Untreated MWCNTs & Acid Red 18 & 166.73 & (Shirmardi et al., n.d.) \\
\hline $\begin{array}{l}\text { Hydrotalcite-based } \\
\text { nanocompounds }\end{array}$ & Remazol Red 3BS & 134.40 & (Asouhidou et al., 2012) \\
\hline $\begin{array}{l}\text { Functionalized hexagonal } \\
\text { mesoporous silica }\end{array}$ & Remazol Red 3BS & 250.0 & (Asouhidou et al., 2009) \\
\hline Graphite oxide/magnetic chitosan & Reactive Black 5 & 391.0 & (Travlou et al., 2013) \\
\hline Fe/Mn oxy-hydroxide ( $\delta$ - & $\mathrm{As}(\mathrm{III})$ & 0.0067 & (Tresintsi et al., 2013) \\
\hline $\left.\mathrm{Fe}_{0.76} \mathrm{Mn}_{0.24} \mathrm{OOH}\right)$ & & & \\
\hline $\begin{array}{l}\text { Magnesium ferrite }\left(\mathrm{Mg}_{0.27} \mathrm{Fe}_{2.50} \mathrm{O}_{4}\right) \\
\text { nanocrystallites }\end{array}$ & $\operatorname{As}(\mathrm{V})$ & 83.20 & (Tang et al., 2013) \\
\hline Anatase nanoadsorbent & As(III) & 16.98 & $\begin{array}{l}\text { (Özlem Kocabaş-Atakli } \\
\text { and Yürüm, 2013) }\end{array}$ \\
\hline $\begin{array}{l}\text { Mercapto-functionalized nano- } \\
\mathrm{Fe}_{3} \mathrm{O}_{4} \text { magnetic polymers }\end{array}$ & $\mathrm{Hg}(I I)$ & 140.0 & (Pan et al., 2012) \\
\hline $\begin{array}{l}\text { Ferrite coated apatite magnetic } \\
\text { nanomaterial }\end{array}$ & $\mathrm{Eu}(\mathrm{III})$ & 157.14 & (Moussa et al., 2013) \\
\hline Carboxymethyl- $\beta$-cyclodextrin & $\mathrm{Cu}(\mathrm{II})$ & 47.20 & (Badruddoza et al., 2011) \\
\hline $\mathrm{Fe}_{3} \mathrm{O}_{4}$ nanoparticles & & & \\
\hline $\mathrm{Fe}_{3} \mathrm{O}_{4} @ \mathrm{COF}(\mathrm{TpPa}-1)$ & $\mathrm{Cr}(\mathrm{VI})$ & 245.45 & (Zhong et al., 2020) \\
\hline
\end{tabular}

\subsection{Contaminated soil management: In-situ remediation and risk benefit assessment}

Soil pollution is a major global concern; the quality of the soil has degraded since the onset of industrialisation and advancement in agricultural techniques. Organic pollutants like pesticides, herbicides and polycyclic aromatic hydrocarbons (PAC) and inorganic 
contaminants like metals (Cadmium, Cd; Copper, Cu; Lead, Pb; Zinc, Zn; Mercury, Hg) and metalloid (Arsenic, As; Antimony, Sb) are the most common forms of soil pollutants added from various sources like military action, mining, road transport and other agricultural, industrial and domestic sources (Pan and Xing, 2012; Pulimi and Subramanian, 2016). These organic contaminants together with inorganic ions do not get chemically or biologically degraded and accumulate in the soil over years inducing adverse effects (Baragano et al., 2020). The deleterious effects of these contaminants can be studied by evaluating their mobility and bioavailability. Bioavailability stands for the fraction of the total chemical load that is available to be transferred to the living organisms. Thus, to reduce their toxicity it is necessary to reduce their availability to the plants and other life forms. Immobilization is one such technique that can effectively reduce the metalloid toxicity in the soil by reducing the amount of mobile and bioavailable fraction of these contaminants by addition of a potential agent to the soil through adsorption, ion exchange or precipitation (Zhong et al., 2021; X. Gong et al., 2018; Y. Gong et al., 2018; Medina-Pérez et al., 2019). Nanoremediation has the potential to reduce the toxicity of soil contaminants by: immobilisation of soil pollutants $(\mathrm{Pb}$, $\mathrm{Cr}, \mathrm{As}, \mathrm{Cd}$ ), conversion of more toxic heavy metals, $\mathrm{Cr}$ (IV) to less toxic forms, $\mathrm{Cr}$ (II) and degradation of organic pollutants like chlorinated organics, DDT, pesticides and herbicides, as illustrated in Figure 8. 


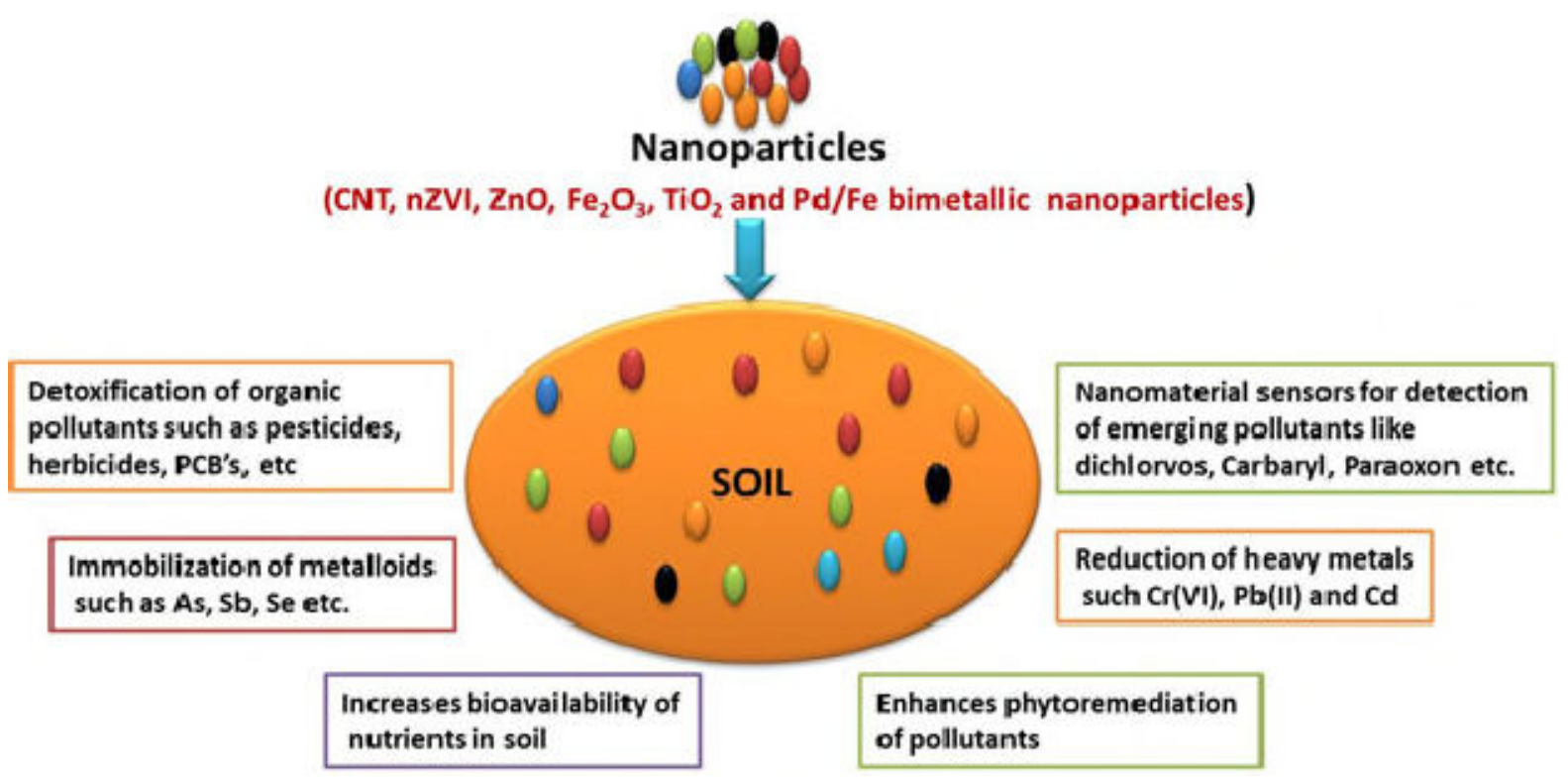

Figure 8. Illustration of pollutant remediation, nutrient biavalaibilty, matallic immoblization in soil using nanomaterials

In the past few decades, the role of nanoparticles as potential soil remediating agents has gained intensive attention across globe owing to their characteristic properties like high surface area, high reactivity and economic viability (Shafi et al., 2020b, Gomez-Sagasti et al., 2019). A wide variety of nanomaterials have been explored over the years for soil remediation such as metal oxides, organic compounds, metal organic frameworks and the recently added and most extensively recognised nanoscale zero-valent iron (nZVI). nZVI has been widely explored to treat organic as well as metalloid soil pollutants. nZVI is composed of a core of $\mathrm{Fe}^{0}$ surrounded by a shell of oxides and hydroxides. It is a good electron donor with high reactivity, excellent adsorption capacity and high surface area. nZVI can be employed for the treatment of organic as well as single and multi-metalloid contaminants (Karn et al., 2009; Xue et al., 2018).

\subsubsection{Immobilization of single metalloid contaminants}

Single metalloid contamination can be effectively treated with the help of immobilising agents. Soil contaminated with elements like As, Cd, Se are severely affecting human health 
if exposed beyond acceptable limit. Selenium, an essential trace element has been widely detected in soil both naturally and through anthropogenic activities. Excessive intake of Se can be hazardous to humans and animals with its bioaccumulation being lethal to fishes and birds. It exists in more toxic Se (IV) and less toxic Se (VI) form with its mobility and transport being redox dependent. Its comparative in-situ immobilization with the help of nanosized Fe-Mn binary oxide stabilised with starch or carboxymethyl cellulose (CMC) was studied and starch stabilised Fe-Mn nanoparticles showed greater Se (IV) adsorption capacity. It was further observed that $>90 \%$ of the leachable Se (IV) treated with nanoparticles was immobilised and retained in the soil matrix (Gong et al., 2018). In another study performed by Xu et al., (2016), Cd contaminated soil was comparatively treated with three types of iron phosphate nanoparticles: $\mathrm{Fe}_{3}\left(\mathrm{PO}_{4}\right)_{2}, \mathrm{FeHPO}_{4}$ and $\mathrm{Fe}\left(\mathrm{H}_{2} \mathrm{PO}_{4}\right)_{2}$. The study revealed that all the three nanoparticles treat $\mathrm{Cd}$ effectively, however $\mathrm{Cd}$ immobilization was best observed for $\mathrm{Fe}_{3}\left(\mathrm{PO}_{4}\right)_{2}$. The study further suggested the formation of cadmium phosphate to be the main reason for diminished bioavailability of $\mathrm{Cd}$ in soil. In another study, $\mathrm{Cd}$ contamination was further treated with the help of biochar supported $\mathrm{Fe}_{3}\left(\mathrm{PO}_{4}\right)_{2}$ nanoparticles. After 28 days of experiment the $\mathrm{Cd}$ immobilization efficiency was found to be $81 \%$ while the bioavailability decreased by $80 \%$ (Qiao et al., 2017). Nanoremediation of Crcontaminated soil has been performed with the help of biochar supported nZVI with the immobilization efficiency of $100 \%$ for $\mathrm{Cr}$ (VI). Further, a significant decrease in phytotoxicity of $\mathrm{Cr}$ (VI) has been observed with enhanced growth of cabbage mustard after the treatment (Su et al., 2016). In another study performed by M. Gil-Díaz et al., (2016), Arsenic, a highly toxic, carcinogenic priority pollutant metalloid was immobilized and the barley plant was cultivated on the treated soil. It was reported that the dose of $10 \%$ of nZVI as compared to $1 \%$ dose effectively immobilized the As. Further, the treatment did not affect the available iron concentration and physico-chemical and biological properties of the soil. 


\subsubsection{Decontamination of multi metalloid contaminants}

The remediation of soil contaminated with multi metalloids is even more complex as the presence of different ions has a retarding or synergetic effect on the immobilization of mixed contaminants. Shipley et al., (2011) demonstrated the application of hematite (an iron oxide) to potentially remove a variety of metal contaminants from soil like $\mathrm{As}, \mathrm{Cd}, \mathrm{V}, \mathrm{Tl}, \mathrm{Pb}, \mathrm{Mn}$, Th, Se and U. Phosphate compounds also present a potential option for immobilising the heavy metal pollutants in the soil. The possibility of hydroxyapatite in immobilizing the $\mathrm{Cu}$ and $\mathrm{Zn}$ was investigated by Sun et al. in the presence of ryegrass plant. The results depicted a significantly retarded bioavailability of $\mathrm{Cu}$ and $\mathrm{Zn}$ to ryegrass plant after the treatment emphasising the effectiveness of hydroxyapatite as an immobilisation material (Sun et al., 2016). The metalloids bioavailability in the soil depends on various factors like $\mathrm{pH}$, type of soil, type of ions and environmental factors. The presence of multiple ions in the soil can also affect their immobilization. M Gil-Díaz et al., (2016) compared the immobilisation of single and multi-metalloid ( $\mathrm{As}, \mathrm{Pb}, \mathrm{Cu}, \mathrm{Cd}, \mathrm{Zn}$ ) contaminated soil with $\mathrm{nZVI}$ and reported effective immobilisation of all metals for single contaminated soil except Cd. Alternatively, for multi metalloid polluted soil, the immobilization was affected by the co-presence of different ions with best immobilization results for $\mathrm{As}$ and $\mathrm{Cr}$ in acidic soil while for $\mathrm{Pb}, \mathrm{Zn}$ and $\mathrm{Cd}$ the immobilization was significant in calcareous soil depicting that the immobilisation was soil, ions dependent. In a recent study, metal oxide nanoparticles $\left(\mathrm{Al}_{2} \mathrm{O}_{3}, \mathrm{TiO}_{2}\right.$ and $\left.\mathrm{SiO}_{2}\right)$ were explored and employed for the remediation of multi-metal $(\mathrm{Cd}, \mathrm{Ni}, \mathrm{Zn})$ contaminated calcareous and non-calcareous soils. The study revealed $\mathrm{SiO}_{2}$ as a potential immobilizing agent for the three metal tested contaminants in calcareous soil while in non-calcareous soil, $\mathrm{Zn}$ and $\mathrm{Cd}$ immobilization was highest for $\mathrm{Al}_{2} \mathrm{O}_{3}$ nanoparticles (Peikam and Jalali, 2018). Moharem et al., (2019) further studies the treatment of calcareous soil polluted with $\mathrm{Cr}$ and $\mathrm{Hg}$ using water treatment residual (drinking water industries by-product) nanoparticles and 
observed a strong sorption capacity of the nanoparticle for $\mathrm{Cr}$ and $\mathrm{Hg}$ with their residual fraction reaching up to 90 and $94 \%$. Mining sites are one of the most heavily metalloid contaminated sites where the soil displays severe physico-chemical and biological limitations like limited organic matter and nutrient content with high concentration of toxic elements making the soil unfit for plant and microbial growth. One such mine site, Iberian Pyrite Belt, was explored for the potential remediation and immobilization of $\mathrm{As}, \mathrm{Pb}$ and $\mathrm{Sb}$ elements with the help of three different nanoparticles- hydroxyapatite, maghemite and hematite. The results depicted a significant decrease in the ion concentration irrespective of the nanoparticle used. However, hydroxyapatite was found to be most effective in limiting the bioavailability of $\mathrm{Pb}$ in the soil as compared to maghemite and hematite while maghemite and hematite were more effective in decreasing Arsenic bioavailability. The Sb bioavailability was observed to be considerably well lowered for all the tested nanoparticles (Arenas-lago et al., 2019).

\subsubsection{Remediation of Organic Contaminants}

Organic chemicals like PAH, pesticides and other persisting and recalcitrant compounds affect the quality of soil making it toxic and unfit for living organism's survival. These pollutants are added to the soil through various sources like organic wastes, disposal, spillage and leakage of chemicals. As these contaminants pose difficulties in biotreatment and are persistent in nature and tend to enter the food chain via food crops and accumulate, threatening the lives of animals and humans alike, they need to be treated and removed from the soil. Various physical (thermal treatment, air sparging) and chemical (photochemical degradation, electrokinetics), biological and phytoremediation techniques have been employed to treat soil contamination. Recently, nanoparticles because of their impressive capabilities like stability, reactivity, mobility and sorption capacity have attained focus as a soil remediation technique (Kuppusamy et al., 2016; Q. Li et al., 2016). In a study performed by $\mathrm{He}$ et al., (2007), Fe-Pd nanoparticles stabilised with sodium carboxymethyl cellulose 
(CMC) are applied for the treatment of trichloroehtene contaminated soil and observed 17 times faster treatment efficiency as compared to the unstabilized nanoparticles. The treatment of soil contaminated with of 2, 4-dichlorophenoxyacetic acid (2,4-D) with the combined effect of $\mathrm{Fe}_{3} \mathrm{O}_{4}$ nanoparticle and indigenous microbial community of soil is investigated by Fang et al., (2012). The results depicted the successful degradation of 2,4-D with a significant decrease in the half-life of 2,4-D as compared to the individual treatment with microbes and $\mathrm{nFe}_{3} \mathrm{O}_{4}$. In another study performed by Machado et al., (2013) the treatment of ibuprofen contaminated sandy soil was performed with the help of nZVI and observed that he nZVI produced from vine extracts could successfully degrade ibuprofen with the highest degradation efficiency of $62 \%$. Wang et al., (2015) successfully demonstrated the viability of silica nanoparticle supported zwitterionic lipid bilayer in treating benzo-a-pyrene, a hydrophobic polycyclic aromatic hydrocarbon. Decabromodiphenyl ether, a type of polybrominated diphenyl ethers present in soil were treated using biochar supported $\mathrm{Fe} / \mathrm{Ni}$ bimetallic nanoparticles with the removal efficiency reaching to nearly $88 \%$ within $72 \mathrm{~h}$ of the treatment. The activity of Fe/Ni bimetallic nanoparticles was found to be an integrated effect of reductive degradation and adsorption. The nanoparticles were also effective in adsorbing and immobilising the bye-product of degradation and $\mathrm{Ni}$ released during the treatment (Wu et al., 2016). DDT although banned worldwide persists in the soil and biomagnifies in food chain affecting the living beings and making it crucial to be treated. However, the treatment of DDT has been observed to be lower in soil (El-Temsah et al., 2016). Polybrominated diphenyl ether (PBDE) are a class of e-wastes that heavily contaminate the soil and can be successfully treated by silica immobilised nZVI up to $78 \%$ within $120 \mathrm{~h}$ of treatment (Xie et al., 2016). Oil transporting pipelines are the major source of oil contamination of fertile soil that greatly affects the soil quality and demands effective treatment. The role of surfactants in solubilising and immobilizing the hydrophobic oil 
contaminants is an attractive approach. A silica nanoparticle stabilised ethanol-sodium lauryl sulphate surfactant was put to test for the remediation of oil contaminated soil and observed the removal efficiency to be nearly $95 \%$ for hydrophobic silica stabilised surfactant as compared to only $75 \%$ for hydrophilic silica stabilised surfactant which was suggested to be the result of higher stabilisation of surfactant foam with hydrophobic silica nanoparticles (Chattopadhyay and Karthick, 2017). One of the critical issues with nZVI is its limited mobility which hampers its efficiency in soil remediation. Techniques like electrokinetic remediation (EK) assist in soil decontamination by application of direct current, which can enhance the mobility and thus performance of nZVI in treating organic contaminants like polychlorinated biphenyls and molinate pesticide (Gomes et al., 2016, 2014). Some of the remediative approaches for the treatment of metal contaminants in soil are shown in Table 4.

Table 4. Application of nanomaterials for contaminated soil remediation

\begin{tabular}{|c|c|c|c|c|}
\hline $\begin{array}{l}\text { Group of } \\
\text { contaminants }\end{array}$ & Contaminant & Nanoparticles used & Treatment remark & Reference \\
\hline Inorganic & As & $\begin{array}{l}\text { Calcareous soil treated } \\
\text { with } \mathrm{nZVI}\end{array}$ & $\begin{array}{l}\text { Increasing nZVI concentration (2.5-25 } \\
\mathrm{g} / \mathrm{kg} \text { ) and constant time treats As } \\
\text { effectively. However, treatment } \\
\text { affected by organic content in soil. }\end{array}$ & $\begin{array}{l}\text { (Azari and } \\
\text { Bostani, } \\
\text { 2017) }\end{array}$ \\
\hline Inorganic & $\mathrm{Cl}, \mathrm{Co}, \mathrm{Cd}, \mathrm{Cd}, \mathrm{Mg}$ & $\begin{array}{l}\text { Soil leachate treated } \\
\text { with DTPA } \\
\text { functionalised } \\
\text { maghemite NPs }\end{array}$ & $\begin{array}{l}\text { Efficient recovery of toxic metals and } \\
\text { remediation of soil-derived } \\
\text { contaminants }\end{array}$ & $\begin{array}{l}\text { (Hughes et } \\
\text { al., 2018) }\end{array}$ \\
\hline Inorganic & $\mathrm{Pb}$ & $\begin{array}{l}\text { Comparative } \\
\text { treatment with } \\
\text { phosphate, compost, } \\
\text { nZVI }\end{array}$ & $\begin{array}{l}\text { nZVI was observed to be least effective } \\
\text { in immobilising } \mathrm{Pb}\end{array}$ & $\begin{array}{l}\text { (Gil-Díaz et } \\
\text { al., 2018) }\end{array}$ \\
\hline Inorganic & As, $\mathrm{Cr}, \mathrm{Cu}, \mathrm{Pb}, \mathrm{Zn}$ & $\begin{array}{l}\text { Micro and nano ZVI } \\
\text { compared }\end{array}$ & $\begin{array}{l}\mathrm{nZVI} \text { more effective than } \mathrm{ZVI} \text { with } \\
\text { highest immobilisation for As. Long } \\
\text { term retention of metal(loid)s more } \\
\text { efficient in ZVI as compared to } \mathrm{nZVI} \text { as } \\
\text { Fe crystallisation is lesser in ZVI than } \\
\mathrm{nZVI}\end{array}$ & $\begin{array}{l}\text { (Danila et } \\
\text { al., 2020) }\end{array}$ \\
\hline Inorganic & As & $\alpha-\mathrm{MnO} 2$ nanorods & Effective treatment of As with & (B. Li et al., \\
\hline
\end{tabular}




\begin{tabular}{|c|c|c|c|c|}
\hline & & treated As in paddy soil & $\begin{array}{l}\text { restricted As influx in rice plants aerial } \\
\text { parts controlling As toxicity }\end{array}$ & 2019) \\
\hline Inorganic & As, $\mathrm{Cd}, \mathrm{Pb}, \mathrm{Zn}$ & $\begin{array}{l}\text { nZVI treatment in } \\
\text { rhizosphere }\end{array}$ & $\begin{array}{l}\text { Soil retention of As, Zn enhanced with } \\
\text { nZVI treatment and significant } \\
\text { decrease in metals uptake by plants. } \\
\text { Sorption suggested to be associated } \\
\text { with Fe/Mn (hydro)oxides and } \\
\text { formation of secondary Fe-As phase }\end{array}$ & $\begin{array}{l}\text { (Vítková et } \\
\text { al., 2018) }\end{array}$ \\
\hline Inorganic & $\mathrm{Cd}, \mathrm{Cu}, \mathrm{Ni}, \mathrm{Pb}$ & $\mathrm{nZVI}$ & $\begin{array}{l}\text { Increased } \mathrm{nZVI} \text { dose reduced the } \\
\text { leaching of treated metals as a result } \\
\text { of higher immobilisation }\end{array}$ & $\begin{array}{l}\text { (Vasarevičiu } \\
\text { s et al., } \\
\text { 2019) }\end{array}$ \\
\hline Inorganic & $\mathrm{Cd}$ & $\begin{array}{l}\text { Iron oxide NPs effect } \\
\text { on Cd contaminated } \\
\text { soil and wheat crop } \\
\text { growth }\end{array}$ & $\begin{array}{l}\text { Reduction in Cd toxicity and increased } \\
\text { Fe concentration in wheat crop } \\
\text { observed }\end{array}$ & $\begin{array}{l}\text { (Hussain et } \\
\text { al., 2019) }\end{array}$ \\
\hline Organic & $\begin{array}{l}\text { PCB (tri and } \\
\text { tetrachlorobiphen } \\
\text { yls) }\end{array}$ & $\begin{array}{l}\text { nZVI combined thermal } \\
\text { desorption (300-600 } \\
\text { oc) }\end{array}$ & $\begin{array}{l}\mathrm{nZVI} \text { enhances the treatment of PCB } \\
\text { by thermal desorption with maximum } \\
\text { treatment efficiency of } 98.35 \%\end{array}$ & $\begin{array}{l}\text { (Liu et al., } \\
\text { 2014) }\end{array}$ \\
\hline Organic & $\begin{array}{l}\text { Polychlorinated } \\
\text { biphenyls } \\
\text { (PCBs) }\end{array}$ & $\begin{array}{l}\text { Combined } \mathrm{nZVI} \text { and } \\
\text { anaerobic composting } \\
\text { treatment }\end{array}$ & $\begin{array}{l}\text { PCB dechlorination improved on } \\
\text { addition of } n Z \mathrm{VI} \text { to composting. }\end{array}$ & $\begin{array}{l}\text { (Long et al., } \\
\text { 2013) }\end{array}$ \\
\hline Organic & $\begin{array}{l}\text { Phenanthrene/Pe } \\
\text { ntachlorophenol }\end{array}$ & $\begin{array}{l}\text { Natural soil NPs } \\
\text { (Inceptisol-NP, Oxisol- } \\
\text { NP, Ultisol-NP) }\end{array}$ & $\begin{array}{l}\text { Phenanthrene mobility influenced by } \\
\text { organic content in soil NPs while } \\
\text { pentachlorophenol mobility mainly } \\
\text { depended on the pH }\end{array}$ & $\begin{array}{l}\text { (F. Liu et al., } \\
\text { 2019) }\end{array}$ \\
\hline
\end{tabular}

Although, nZVI is considered a widely recognised option for soil remediation, its effect on the physiological properties and microbial communities of soil is crucial to be studied for potential toxicity and negative effect. Fajardo et al., (2015) investigated the residual toxicity and potential impact of aged $\mathrm{nZVI}$ on the $\mathrm{Pb}$ and $\mathrm{Zn}$ polluted soils. Although no effect on the physiological properties of soil was observed, and the Fe concentration was noticed to be significantly increased after the treatment. The toxicological study performed on C. elegans (a soil dwelling nematode) revealed a retarded growth in the $\mathrm{Pb}$ polluted nZVI treated soil 
while for $\mathrm{Zn}$ contaminated soil a reduced toxicity of $\mathrm{Zn}$ on C. elegans after treatment with aged nZVI. The study thus suggested the pollutant-nZVI interaction as one of the significant factor in remediation of heavy metal contaminated soil. In another study, the effects of nZVI concentration on soil biota in the clay loam and sandy loam soil revealed that the biota of sandy loam was more vulnerable to nZVI than clay loam soil and suggested the negligible impact on biota of clay loam soil rendering nZVI inactive thereby diminishing its interaction with soil biota (Gomez-Sagasti et al., 2019). In a recent study performed by Baragano et al., (2020) a new graphene oxide nanoparticle (nGOx) was tested as an alternative to nZVI. The remediation of Arsenic contaminated soil revealed a reduction in bioavailability on treatment with nZVI, while an increase was observed on application of nGOx deeming them fit for immobilisation and phytoextraction techniques respectively. The performance of nGOx was compatible with nZVI for the remediation of $\mathrm{Cd}, \mathrm{Pb}$ and $\mathrm{Zn}$ while for $\mathrm{Cu}$ it performed significantly better than nZVI. Further the physico-chemical properties of soil were also observed to improve on application of nGOx making it a potential strategy for soil remediation.

\subsubsection{Management of nutrients in soil}

Nanotechnology has a budding capability to bring sustainability in the prospects of agriculture and its allied fields which include food science, fisheries, aquaculture, horticulture, vegetable sciences, veterinary sciences and animal husbandry (Prasad et al., 2017; Salata, 2004). In agriculture, the main goal is to decline the utilization of fertilizers and pesticides besides the improvement in crop yields by proper nutrient management (Mukhopadhyay, 2014). Nanotechnology is offering promising sustainable tools like nanoemulsions, nano-agrochemical coatings, microencapsulation, and other active constituents to boost the nutrient availability for soil and plants. 
Nanotechnology has potentially developed the new methods of food packaging which may include nanocomposite active packaging, nanocomposite smart packaging and nanoreinforcement packaging (Kuswandi, 2016). Nanocomposite food packaging has potential to work against microbes by liberation of some useful compounds which are antimicrobial or antioxidant and improves the food stability, enhances the shelf life and oxygen scavenging property (Sharma et al., 2017). Moreover, nanotechnology can play an important role in improving the germination ability of agricultural seeds, which are otherwise less germinative. Various techniques were implemented for increasing germination percentage like the use of nano-polymer, nano-sensors, nano-barcodes, etc. It is reported that carbon nanotubes were utilized for increasing the germination of tomato seeds by raising the effective penetration of moisture content (Mondal et al., 2011).

\section{Practical implications of nanoparticles and consensus recommendation for future}

\section{research needs}

Although, nanoparticles (NP) can deliver cost effective and facile on-site remediation of vast number of contaminated sites, but the technology lacks the certification of complete sustainable approach because of the uncertainties associated with the use of nanoparticles. Currently, the fate and transport of nanoparticles in the contaminated sites, whether it may soil, drinking water or air is still unclear and doubtful and has become a major hindrance in evaluating risk assessment of the nanomaterials. The potential risks to the human or ecological health are associated with the dispersal, ecotoxicity, persistency, bioaccumulation and reversibility of the nanoparticles. The understanding of these principles lacks background literature and underlying topics are still evolving. Moreover, the application of nanoparticles lacks proper regulatory or legislative guidelines at national and international levels (Corsi et al., 2018; Patil et al., 2016). 
Keeping in view the ecological and health risks associated with the use of nanotechnology, further research needs to be conducted in this field with special focus on the ecological concerns. The consensus recommendations for the effective application of nanotechnology and sustainable remediation of environment are as follows (see figure 9):

1). Greener and sustainable approaches for synthesis of nanomaterials. (i.e. bionanocomposites, emulsified nZVI, EAB mediated nanoparticle synthesis, etc.)

2). Assessment of remediation plan for sustainability considerations as per SuRF-UK indicator checklist

3). Development of advanced tools for ecotoxicological assessment and safety measures (i.e. biomarkers, permeable iron barriers, PIBs, nanoparticles with new coatings and surface functionalised groups),

4). Establishment of regulatory bodies at national and international level to monitor the distribution of nanoparticles in environmental medias and deploy nano-enabled techniques for better outcomes, limiting the negative impacts to possible minimum,

5). Strong collaboration between researchers and industrial sector. 


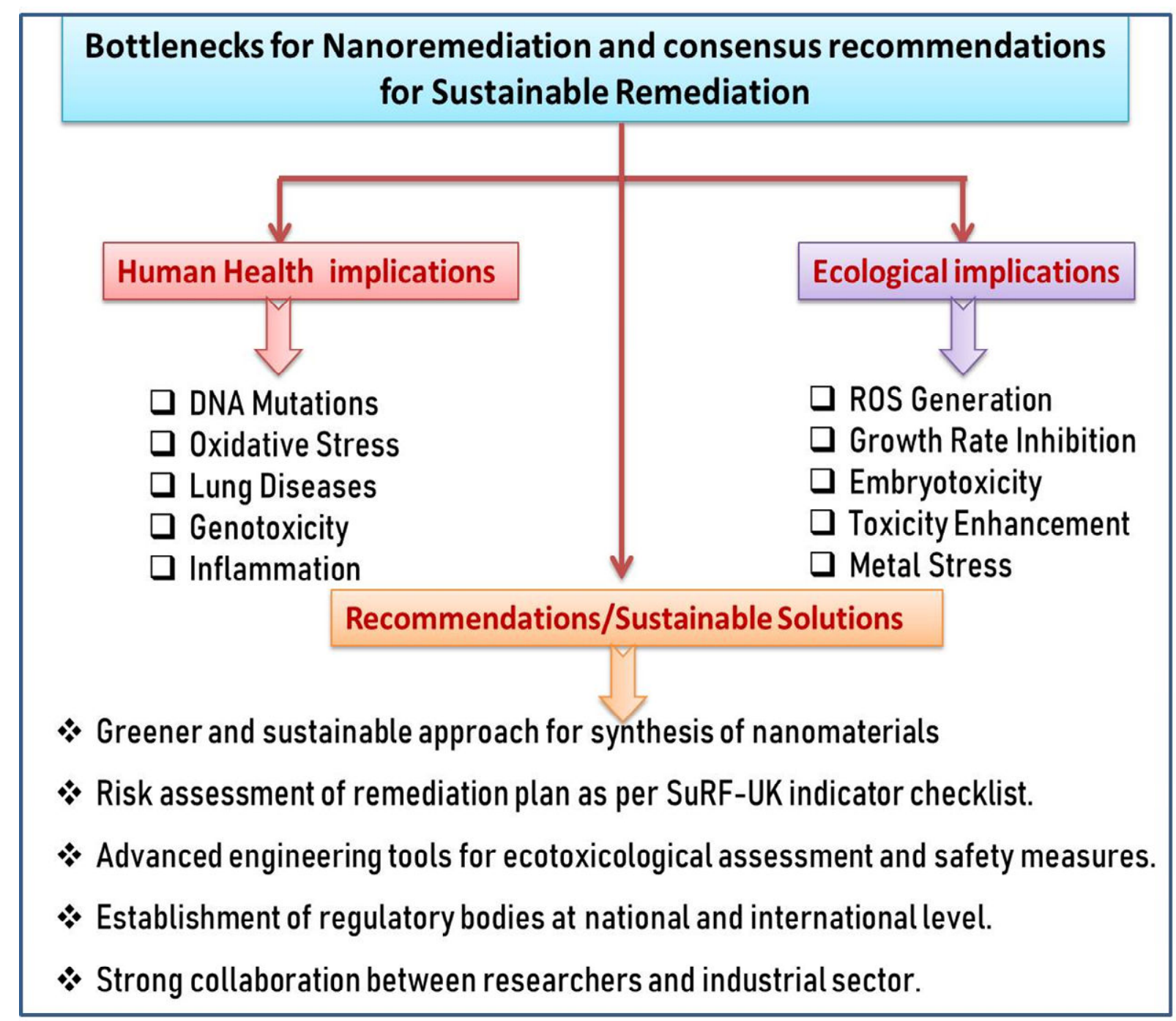

Figure 9. Practical implications of nanotechnology with consensus recommendation for sustainable remediation of environment

\section{Conclusion}

In summary, nano-based remediation technologies are emerging tools to mitigate the pollution crisis all over globe, whether it may be air, water or soil pollution. Nanoengineered materials (NEMs) like nanoadsorbents, nanomembranes, nanosensors, modified photocatalysts, metallic nanoparticles have shown promising potential for the environmental remediation due to their structural robustness and improved surface properties. 
The manipulation of materials at nano-dimensions offers several potential properties to the matter which has been utilized for multitude of applications. The characteristic properties like high surface to volume ratio, functional surface structures, tunable absorption properties, high adsorption capability, chemical stability and above all cost effectiveness have made these materials efficient and effective for monitoring and safeguarding the status of environment.

Apart from this, nanoremediation techniques can treat persistent pollutants by both chemical reduction and catalytic processes and can be beneficial in reducing the clean-up time and avoiding degradation intermediates. Although nanoremediation techniques have shown plethora of applications but they are yet to penetrate mass markets due to ecological concerns. Most of the nanoremediation techniques are limited to the laboratory premises with

much less commercialization. Therefore, the commercialization of nanoremediation techniques is highly needed to ensure their proper sustainable use for maintaining ecological and public health.

\section{Acknowledgement}

Authors are highly thankful to Department of Chemistry and University Sophisticated Instrumentation Facility (USIF), Aligarh Muslim University for providing the requisite research facility. UGC and DST are duly acknowledged for research grant.

Conflicts of Interest: The authors declare no conflicts of interest. 


\section{References}

Abhilash, P. C., Tripathi, V., Edrisi, S. A., Dubey, R. K., Bakshi, M., Dubey, P. K., Singh, H. B., \& Ebbs, S. D. (2016). Sustainability of crop production from polluted lands. Energy, Ecology and Environment, 1(1), 54-65. https://doi.org/10.1007/s40974-016-0007-x

Aghabeygi, S., \& Khademi-Shamami, M. (2018). ZnO/ZrO2 nanocomposite: Sonosynthesis, characterization and its application for wastewater treatment. Ultrasonics Sonochemistry, 41, 458-465. https://doi.org/10.1016/j.ultsonch.2017.09.020

Ahmadi, Z., Ramezani, H., Azizi, S. N., \& Chaichi, M. J. (2020). Synthesis of zeolite NaY supported Mn-doped $\mathrm{ZnS}$ quantum dots and investigation of their photodegradation ability towards organic dyes. Environmental Science and Pollution Research, 27, 97079717. https://doi.org/10.1007/s11356-019-07192-6

Ajmal, A., Majeed, I., Malik, R. N., Idriss, H., \& Nadeem, M. A. (2014). Principles and mechanisms of photocatalytic dye degradation on TiO 2 based photocatalysts: A comparative overview. RSC Advances, 4, (70), 37003-37026. https://doi.org/10.1039/c4ra06658h

Akir, S., Hamdi, A., Addad, A., Coffinier, Y., Boukherroub, R., \& Dakhlaoui Omrani, A. (2017). Facile synthesis of carbon- $\mathrm{ZnO}$ nanocomposite with enhanced visible light photocatalytic performance. Applied Surface Science, 400, 461-470. https://doi.org/10.1016/j.apsusc.2016.12.212

Al-mokaram, A. M. A. A. A., Yahya, R., \& Abdi, M. M. (2017). Development of NonEnzymatic Glucose Biosensors Based on Electrochemically Prepared PolypyrroleChitosan-Titanium Dioxide Nanocomposite Films. Nanomaterials, 7(129), 1-10. https://doi.org/10.3390/nano7060129 
Andreozzi, R., Caprio, V., Insola, A., \& Marotta, R. (1999). Advanced oxidation processes (AOP) for water purification and recovery. Catalysis Today, 53(1), 51-59. https://doi.org/10.1016/S0920-5861(99)00102-9

Anjaneyulu, Y., Sreedhara Chary, N., \& Samuel Suman Raj, D. (2005). Decolourization of industrial effluents - Available methods and emerging technologies - A review. Reviews in Environmental Science and Biotechnology, 4(4), 245-273. https://doi.org/10.1007/s11157-005-1246-Z

Anjum, M., Miandad, R., Waqas, M., Gehany, F., \& Barakat, M. A. (2019). Remediation of wastewater using various nano-materials. Arabian Journal of Chemistry, 12(8), 48974919. https://doi.org/10.1016/j.arabjc.2016.10.004

Arenas-lago, D., Abreu, M. M., Couce, L. A., \& Vega, F. A. (2019). Is nanoremediation an effective tool to reduce the bioavailable $\mathrm{As}, \mathrm{Pb}$ and $\mathrm{Sb}$ contents in mine soils from Iberian Pyrite Belt? Catena, 176(2018), 362-371. https://doi.org/10.1016/j.catena.2019.01.038

Arora, A. K., Jaswal, V. S., Singh, K., \& Singh, R. (2016). Applications of metal/mixed metal oxides as photocatalyst: A review. Oriental Journal of Chemistry, 32(4) 20352042. https://doi.org/10.13005/ojc/320430

Arora, N. K., Fatima, T., Mishra, I., Verma, M., Mishra, J., \& Mishra, V. (2018). Environmental sustainability: challenges and viable solutions. Environmental Sustainability, 1(4), 309-340. https://doi.org/10.1007/s42398-018-00038-w

Arora, N. K., \& Mishra, I. (2019). United Nations Sustainable Development Goals 2030 and environmental sustainability: race against time. Environmental Sustainability, 2(4), 339342. https://doi.org/10.1007/s42398-019-00092-y 
Ashraf, M. A. (2017). Persistent organic pollutants (POPs): a global issue, a global challenge. Environmental Science and Pollution Research, 24(5), 4223-4227. https://doi.org/10.1007/s11356-015-5225-9

Asouhidou, D. D., Triantafyllidis, K. S., Lazaridis, N. K., \& Matis, K. A. (2009). Adsorption of Remazol Red 3BS from aqueous solutions using APTES- and cyclodextrin-modified HMS-type mesoporous silicas. Colloids and Surfaces A: Physicochemical and Engineering Aspects, 346(1-3), 83-90. https://doi.org/10.1016/j.colsurfa.2009.05.029

Asouhidou, D. D., Triantafyllidis, K. S., Lazaridis, N. K., \& Matis, K. A. (2012). Adsorption of reactive dyes from aqueous solutions by layered double hydroxides. Journal of $\begin{array}{llll}\text { Chemical Technology } \quad \& \quad \text { Biotechnology, } & \text { 87(4), } & \text { 575-582. }\end{array}$ https://doi.org/10.1002/jctb.2755

Axet, M. R., Durand, J., Gouygou, M., \& Serp, P. (2019). Surface coordination chemistry on graphene and two-dimensional carbon materials for well-defined single atom supported catalysts. Advances in Organometallic Chemistry, 71, 53-174. https://doi.org/10.1016/bs.adomc.2019.01.002

Azari, P., \& Bostani, A. A. (2017). Reducing As availability in calcareous soils using nanoscale zero valent iron. Environmental Science and Pollution Research, 24(25), 20438-20445. https://doi.org/10.1007/s11356-017-9447-x

Babel, S., \& Agustiono Kurniawan, T. (2003). Low-cost adsorbents for heavy metals uptake from contaminated water: a review. Journal of Hazardous Materials, 97(1-3), 219-243. https://doi.org/10.1016/s0304-3894(02)00263-7

Baby, R., Saifullah, B., \& Hussein, M. Z. (2019). Carbon Nanomaterials for the Treatment of Heavy Metal-Contaminated Water and Environmental Remediation. Nanoscale 
Research Letters 14(1), 1-17. https://doi.org/10.1186/s11671-019-3167-8

Badruddoza, A. Z. M., Tay, A. S. H., Tan, P. Y., Hidajat, K., \& Uddin, M. S. (2011). Carboxymethyl- $\beta$-cyclodextrin conjugated magnetic nanoparticles as nano-adsorbents for removal of copper ions: Synthesis and adsorption studies. Journal of Hazardous Materials, 185(2-3), 1177-1186. https://doi.org/10.1016/j.jhazmat.2010.10.029

Bano, S., Ahmad, N., Sultana, S., Sabir, S., \& Khan, M. Z. (2019). Preparation and study of ternary polypyrrole-tin oxide-chitin nanocomposites and their potential applications in visible light photocatalysis and sensors. Journal of Environmental Chemical Engineering, 7(2), 103012. https://doi.org/10.1016/j.jece.2019.103012

Bai, X., Wang, L., Zong, R., Lv, Y., Sun, Y., \& Zhu, Y. (2013). Performance Enhancement of $\mathrm{ZnO}$ Photocatalyst via Synergic Effect of Surface Oxygen Defect and Graphene Hybridization. Langmuir, 29(9), 3097-3105. https://doi.org/10.1021/la4001768

Baragano, D., Alonso, J., Gallego, J. R., Lobo, M. C., \& Gil-díaz, M. (2020). Zero valent iron and goethite nanoparticles as new promising remediation techniques for As-polluted soils. Chemosphere, 238, 124624. https://doi.org/10.1016/j.chemosphere.2019.124624

Baragaño, D., Forján, R., Welte, L., \& Gallego, J. L. R. (2020). Nanoremediation of As and metals polluted soils by means of graphene oxide nanoparticles. Scientific Report, 10(1), 1896. https://doi.org/10.1038/s41598-020-58852-4

Bardos, R., Thomas, H., Smith, J., Harries, N., Evans, F., Boyle, R., Howard, T., Lewis, R., Thomas, A., \& Haslam, A. (2018). The Development and Use of Sustainability Criteria in SuRF-UK's Sustainable Remediation Framework. Sustainability, 10(6), 1781. https://doi.org/10.3390/su10061781

Barrington-Leigh, C. (2016). Sustainability and well-being: A happy synergy. Development 
(Basingstoke), 59(3-4), 292-298. https://doi.org/10.1057/s41301-017-0113-х

Bates, M. E., Grieger, K. D., Trump, B. D., Keisler, J. M., Plourde, K. J., \& Linkov, I. (2016). Emerging Technologies for Environmental Remediation: Integrating Data and Judgment. Environmental Science and Technology, 50(1), 349-358. https://doi.org/10.1021/acs.est.5b03005

Belal, E.-S., \& El-Ramady, H. (2016). Nanoparticles in Water, Soils and Agriculture: Nanoscience in Food and Agriculture 2, 311-358. Springer, Cham. https://doi.org/10.1007/978-3-319-39306-3_10

Bhargava, R., \& Khan, S. (2018). Enhanced optical properties of $\mathrm{Cu} 2 \mathrm{O}$ anchored on reduced graphene oxide (rGO) sheets. Journal of Physics Condensed Matter, 30(33), 335703. https://doi.org/10.1088/1361-648X/aad2b2

Bianchi, R. C., Rodrigo, E., Antonia, L. H. D., Ferreira, F. F., \& Alves, W. A. (2014). A Nonenzymatic Biosensor Based on Gold Electrodes Modi fi ed with Peptide SelfAssemblies for Detecting Ammonia and Urea Oxidation. Langmuir, 30(38), 11464 11473. https://doi.org/10.1021/la502315m

Bonaiti, S., Calderon, B., \& Collina, E. (2017). Review on Nano zerovalent Iron (nZVI): From Modification to Environmental Applications Related content. IOP Conference Series: Earth and Environmental Science, 51, 012004. https://doi.org/10.1088/1755$1315 / 51 / 1 / 012004$

Bondarenko, O., Juganson, K., Ivask, A., Kasemets, K., Mortimer, M., \& Kahru, A. (2013). Toxicity of $\mathrm{Ag}, \mathrm{CuO}$ and $\mathrm{ZnO}$ nanoparticles to selected environmentally relevant test organisms and mammalian cells in vitro: A critical review. Archives of Toxicology, 87(7), 1181-1200. https://doi.org/10.1007/s00204-013-1079-4 
Botta, S. G., Navío, J. A., Hidalgo, M. C., Restrepo, G. M., \& Litter, M. I. (1999). Photocatalytic properties of $\mathrm{ZrO} 2$ and $\mathrm{Fe} / \mathrm{ZrO} 2$ semiconductors prepared by a sol-gel technique. Journal of Photochemistry and Photobiology A: Chemistry, 129(1-2), 89-99. https://doi.org/10.1016/S1010-6030(99)00150-1

Bouqellah, N. A., Mohamed, M. M., \& Ibrahim, Y. (2019). Synthesis of eco-friendly silver nanoparticles using Allium sp. and their antimicrobial potential on selected vaginal bacteria. Saudi Journal of Biological Sciences, 26(7), 1789-1794. https://doi.org/10.1016/j.sjbs.2018.04.001

Cai, W., Liu, C., Jia, S., Chan, F. T. S., Ma, M., \& Ma, X. (2019). An emergy-based sustainability evaluation method for outsourcing machining resources. Journal of Cleaner Production. https://doi.org/10.1016/j.jclepro.2019.118849

Caliman, F. A., Robu, B. M., Smaranda, C., Pavel, V. L., \& Gavrilescu, M. (2011). Soil and groundwater cleanup: Benefits and limits of emerging technologies. Clean Technologies and Environmental Policy, 13(2), 241-268. https://doi.org/10.1007/s10098-010-0319-z

Cardoso, N. F., Lima, E. C., Royer, B., Bach, M. V., Dotto, G. L., Pinto, L. A. A., \& Calvete, T. (2012). Comparison of Spirulina platensis microalgae and commercial activated carbon as adsorbents for the removal of Reactive Red 120 dye from aqueous effluents. Journal Hazardous Materials, 241-242, 146-153. https://doi.org/10.1016/j.jhazmat.2012.09.026

Charanpahari, A., Gupta, N., Devthade, V., Ghugal, S., \& Bhatt, J. (2018). Ecofriendly Nanomaterials for Sustainable Photocatalytic Decontamination of Organics and Bacteria. Handbook of Ecomaterials, 1-29. Springer International Publishing. https://doi.org/10.1007/978-3-319-48281-1_179-1 
Chattopadhyay, P., \& Karthick, R. A. (2017). Characterization and Application of Surfactant Foams Produced from Ethanol-Sodium Lauryl Sulfate-Silica Nanoparticle Mixture for Soil Remediation. Macromolecular Symposia, $\quad 376(1), \quad 1600182$. https://doi.org/10.1002/masy.201600182

Chaudhry, Q., Scotter, M., Blackburn, J., Ross, B., Boxall, A., Castle, L., Aitken, R., \& Watkins, R. (2008). Applications and implications of nanotechnologies for the food sector. In Food Additives and Contaminants - Part A Chemistry, Analysis, Control, Exposure Risk Assessment, 25(3), 241-258. https://doi.org/10.1080/02652030701744538

Chiu, K. L., Ponzoni, A., \& Der, F. G. (2019). Cellulose Fibers Enable Near-Zero-Cost Electrical Sensing of Water- Soluble Gases. ACS Sensors, 4(6), 1662-1669. https://doi.org/10.1021/acssensors.9b00555

Corsi, I., Winther-Nielsen, M., Sethi, R., Punta, C., Della Torre, C., Libralato, G., Lofrano, G., Sabatini, L., Aiello, M., Fiordi, L., Cinuzzi, F., Caneschi, A., Pellegrini, D., \& Buttino, I. (2018). Ecofriendly nanotechnologies and nanomaterials for environmental applications: Key issue and consensus recommendations for sustainable and ecosafe nanoremediation. Ecotoxicology and Environmental Safety, 154, 237-244. https://doi.org/10.1016/j.ecoenv.2018.02.037

Cretu, V., Postica, V., Mishra, A. K., Hoppe, M., Tiginyanu, I., Mishra, Y. K., Chow, L., De Leeuw, N. H., Adelung, R., \& Lupan, O. (2016). Synthesis, characterization and DFT studies of zinc-doped copper oxide nanocrystals for gas sensing applications. Journal of Materials Chemistry A, 4(17), 6527-6539. https://doi.org/10.1039/c6ta01355d

Cui, Y., Wei, Q., Park, H., \& Lieber, C. M. (2001). Nanowire nanosensors for highly sensitive and selective detection of biological and chemical species. Science, 293(5533), 
1289-1292. https://doi.org/10.1126/science.1062711

da Rocha, O. R. S., Dantas, R. F., Duarte, M. M. M. B., Duarte, M. M. L., \& da Silva, V. L. (2010). Oil sludge treatment by photocatalysis applying black and white light. Chemical Engineering Journal, 157(1), 80-85. https://doi.org/10.1016/j.cej.2009.10.050

Danila, V., Kumpiene, J., Kasiuliene, A., \& Vasarevičius, S. (2020). Immobilisation of metal(loid)s in two contaminated soils using micro and nano zerovalent iron particles: Evaluating the long-term stability. Chemosphere, 248, 126054. https://doi.org/10.1016/j.chemosphere.2020.126054

Das, A., Kamle, M., Bharti, A., \& Kumar, P. (2019). Nanotechnology and it's applications in environmental remediation: an overview. Vegetos, 32(3), 227-237. https://doi.org/10.1007/s42535-019-00040-5

Das, M., \& Chatterjee, S. (2019). Green synthesis of metal/metal oxide nanoparticles toward biomedical applications: Boon or bane. Green Synthesis, Characterization and Applications of Nanoparticles, 265-301. Elsevier. https://doi.org/10.1016/b978-0-08$102579-6.00011-3$

Das, S., Sen, B., \& Debnath, N. (2015). Recent trends in nanomaterials applications in environmental monitoring and remediation. Environmental Science and Pollution Research, 22(23), 18333-18344. https://doi.org/10.1007/s11356-015-5491-6

Datta, R. S., Ou, J. Z., Mohiuddin, M., Carey, B. J., Zhang, B. Y., Khan, H., Syed, N., Zavabeti, A., Haque, F., Daeneke, T., \& Kalantar-zadeh, K. (2018). Two dimensional PbMoO4: A photocatalytic material derived from a naturally non-layered crystal. Nano Energy, 49, 237-246. https://doi.org/10.1016/j.nanoen.2018.04.041

Deng, Y., Li, Z., Tang, R., Ouyang, K., Liao, C., Fang, Y., Ding, C., Yang, L., Su, L., \& 
Gong, D. (2020). What will happen when microorganisms "meet" photocatalysts and photocatalysis?. Environmental Science: Nano, 7(3), 702-723. https://doi.org/10.1039/c9en01318k

Devi, L. G., \& Shyamala, R. (2018). Photocatalytic activity of SnO2-a-Fe2O3 composite mixtures: Exploration of number of active sites, turnover number and turnover frequency. Materials Chemistry Frontiers, 2(4), 796-806. https://doi.org/10.1039/c7qm00536a

Diamandescu, L., Vasiliu, F., Tarabasanu-Mihaila, D., Feder, M., Vlaicu, A. M., Teodorescu, C. M., Macovei, D., Enculescu, I., Parvulescu, V., \& Vasile, E. (2008). Structural and photocatalytic properties of iron- and europium-doped TiO 2 nanoparticles obtained under hydrothermal conditions. Materials Chemistry and Physics, 112(1), 146-153. https://doi.org/10.1016/j.matchemphys.2008.05.023

Divya, K. S., Xavier, M. M., Vandana, P. V., Reethu, V. N., \& Mathew, S. (2017). A quaternary $\mathrm{TiO} 2 / \mathrm{ZnO} / \mathrm{RGO} / \mathrm{Ag}$ nanocomposite with enhanced visible light photocatalytic performance. New Journal of Chemistry, 41(14), 6445-6454. https://doi.org/10.1039/c7nj00495h

Dong, P., Yang, B., Liu, C., Xu, F., Xi, X., Hou, G., \& Shao, R. (2017). Highly enhanced photocatalytic activity of WO3 thin films loaded with Pt-Ag bimetallic alloy nanoparticles. RSC Advances, 7(2), 947-956. https://doi.org/10.1039/c6ra25272a

Du, Y., Zhou, X., Qu, Y., Liu, J., Feng, Y., \& Ren, N. (2017). Enhanced Electricity Generation and Pollutant Degradation by Hybrid Photoelectrochemical and Microbial Fuel Cells. Energy Technology, 5(3), 402-405. https://doi.org/10.1002/ente.201600339

El-Ramady, H., Alshaal, T., El-Henawy, A., Abdalla, N., Taha, H., Elmahrouk, M., Shalaby, 
T., Elsakhawy, T., Omara, A. E.-D., elmarsafawy, S., Elhawat, N., \& Shehata, S. (2017). Environmental Nanoremediation under Changing Climate. Environment, Biodiversity and Soil Security, 1(2017), 190-200. https://doi.org/10.21608/jenvbs.2017.1550.1009

El-Temsah, Y. S., Sevcu, A., Bobcikova, K., Cernik, M., \& Joner, E. J. (2016). DDT degradation efficiency and ecotoxicological effects of two types of nano-sized zerovalent iron (nZVI) in water and soil. Chemosphere, 144, 2221-2228. https://doi.org/10.1016/j.chemosphere.2015.10.122

Fajardo, C, Gil-díaz, M., Costa, G., Alonso, J., Guerrero, A. M., Nande, M., Lobo, M. C., \& Martín, M. (2015). Residual impact of aged nZVI on heavy metal-polluted soils. Science of the Total Environment, 535, 79-84. https://doi.org/10.1016/j.scitotenv.2015.03.067

Fajardo, Carmen, Sánchez-Fortún, S., Costa, G., Nande, M., Botías, P., García-Cantalejo, J., Mengs, G., \& Martín, M. (2020). Evaluation of nanoremediation strategy in a Pb, Zn and Cd contaminated soil. Science of the Total Environment, 706, 136041. https://doi.org/10.1016/j.scitotenv.2019.136041

Fang, G., Si, Y., Tian, C., Zhang, G., \& Zhou, D. (2012). Degradation of 2, 4-D in soils by Fe3O4 nanoparticles combined with stimulating indigenous microbes. Environ Sci Pollut Res, 19(3), 784-793. https://doi.org/10.1007/s11356-011-0597-y

Fangqing Liu, Yi Zhuang, Mingliang Guo, Yongjun Chen, J. T. and L. D. (2018). 3D Copper Foam-Supported CuCo 2 O 4 Nanosheet Arrays as Electrode for Enhanced NonEnzymatic Glucose Sensing. Sensors, 18(1131), 1-11. https://doi.org/10.3390/s18041131

Feng, C., Jiang, Z., Chen, B., Cheng, P., Wang, Y., \& Huang, C. (2019). Aluminum-doped $\mathrm{NiO}$ nanofibers as chemical sensors for selective and sensitive methanol detection. 
Analytical Methods, 11(5), 575-581. https://doi.org/10.1039/c8ay02460j

Fujishima, A., Rao, T. N., \& Tryk, D. A. (2000). Titanium dioxide photocatalysis. Journal of Photochemistry and Photobiology C: Photochemistry Reviews 1(1), 1-21. https://doi.org/10.1016/S1389-5567(00)00002-2

Ganesh, R. S., Durgadevi, E., Navaneethan, M., Sharma, S. K., Binitha, H. S., Ponnusamy, S., Muthamizhchelvan, C., \& Hayakawa, Y. (2017). Visible light induced photocatalytic degradation of methylene blue and rhodamine B from the catalyst of CdS nanowire. Chemical Physics Letters, 684, 126-134. https://doi.org/10.1016/j.cplett.2017.06.021

Ganie, A.S., Bano, S., Sultana, S., Sabir, S., Khan, M.Z., 2021. Ferrite Nanocomposite Based Electrochemical Sensor: Characterization, Voltammetric and Amperometric Studies for Electrocatalytic Detection of Formaldehyde in Aqueous Media. Electroanalysis. 33, 233-248. https://doi.org/10.1002/elan.202060179

Gehrke, I., Geiser, A., \& Somborn-Schulz, A. (2015). Innovations in nanotechnology for water treatment. Nanotechnology, Science and Applications, 8, 1-17. https://doi.org/10.2147/NSA.S43773

Ghasemzadeh, G., Momenpour, M., Omidi, F., Hosseini, M. R., Ahani, M., \& Barzegari, A. (2014). Applications of nanomaterials in water treatment and environmental remediation. Frontiers of Environmental Science and Engineering, 8, 471-482. https://doi.org/10.1007/s11783-014-0654-0

Gil-Díaz, M., Diez-Pascual, S., Gonzalez, A., Alonso, J., Rodríguez-vald, E., Gallego, J. R., \& Lobo, M. C. (2016). A nanoremediation strategy for the recovery of an As-polluted soil. Chemosphere, 149, 137-145. https://doi.org/10.1016/j.chemosphere.2016.01.106

Gil-Díaz, M., López, L. F., Alonso, J., \& Lobo, M. C. (2018). Comparison of Nanoscale 
Zero-Valent Iron, Compost, Phosphate for Pb Immobilization in an Acidic Soil. Water, Air, and Soil Pollution, 229(10), 1-11. https://doi.org/10.1007/s11270-018-3972-1

Gil-Díaz, M., Rodríguez-Valdés, E., Alonso, J., Baragaño, D., Gallego, J. R., \& Lobo, M. C. (2019). Nanoremediation and long-term monitoring of brownfield soil highly polluted with As and Hg. Science of the Total Environment, 675, 165-175. https://doi.org/10.1016/j.scitotenv.2019.04.183

Gomes, H. I., Fan, G., Mateus, E. P., Dias-Ferreira, C., \& Ribeiro, A. B. (2014). Assessment of combined electro-nanoremediation of molinate contaminated soil. Science of The Total Environment, 493, 178-184. https://doi.org/10.1016/j.scitotenv.2014.05.112

Gomes, H. I., Fan, G., Ottosen, L. M., Dias-Ferreira, C., \& Ribeiro, A. B. (2016). Electrokinetics Across Disciplines and Continents. New Strategies for Sustainable Development, 1-453, Springer Cham. https://doi.org/10.1007/978-3-319-20179-5

Gomez-Sagasti, M. T., Epelde, L., Anza, M., Urra, J., Alkorta, I., \& Garbisu, C. (2019). The impact of nanoscale zero-valent iron particles on soil microbial communities is soil dependent. Journal of Hazardous Materials, 364, 591-599. https://doi.org/10.1016/j.jhazmat.2018.10.034

Gong, X., Huang, D., Liu, Y., Peng, Z., Zeng, G., Xu, P., Cheng, M., Wang, R., \& Wan, J. (2018). Remediation of contaminated soils by biotechnology with nanomaterials : biobehavior, applications, and perspectives. Critical Reviews in Biotechnology, 38(3), 455468. https://doi.org/10.1080/07388551.2017.1368446

Gong, Y., Zhao, D., \& Wang, Q. (2018). An overview of field-scale studies on remediation of soil contaminated with heavy metals and metalloids: Technical progress over the last decade. Water Research, 147, 440-460. https://doi.org/10.1016/j.watres.2018.10.024 
Grassi, M., Kaykioglu, G., Belgiorno, V., \& Lofrano, G. (2012). Removal of Emerging Contaminants from Water and Wastewater by Adsorption Process, 15-37. Springer, Dordrecht. https://doi.org/10.1007/978-94-007-3916-1_2

Guerra, F. D., Attia, M. F., Whitehead, D. C., \& Alexis, F. (2018). Nanotechnology for Environmental Remediation: Materials and Applications. Molecules (Basel, Switzerland), 3, 1760. https://doi.org/10.3390/molecules23071760

Guo, H., Zheng, Z., Zhang, Y., Lin, H., \& Xu, Q. (2017). Highly selective detection of Pb2+ by a nanoscale Ni-based metal-organic framework fabricated through one-pot hydrothermal reaction. Sensors and Actuators, B: Chemical, 248, 430-436. https://doi.org/10.1016/j.snb.2017.03.147

Guo, Zhanhu, Chen, Y., Lu, N. L., Qin, Z., Su, T., \& Ji, H. (2018). Photocatalytic Nanomaterials for the Energy and Environmental Application. Multifunctional Nanocomposites for Energy and Environmental Applications, 353-401. Wiley-VCH Verlag GmbH \& Co. KGaA. https://doi.org/10.1002/9783527342501.ch13

Guo, Zhen, Zhang, Z., Zhang, W., Zhou, L., Li, H., Wang, H., Andreazza-Vignolle, C., Andreazza, P., Zhao, D., Wu, Y., Wang, Q., Zhang, T., \& Jiang, K. (2014). Colorswitchable, emission-enhanced fluorescence realized by engineering C-dot@C-dot nanoparticles. ACS Applied Materials and Interfaces, 6(23), 20700-20708. https://doi.org/10.1021/am5071078

Gupta, S. M., \& Tripathi, M. (2011). A review of TiO2 nanoparticles. Chinese Science Bulletin 56(16), 1639-1657. https://doi.org/10.1007/s11434-011-4476-1

Gupta, V. K., Tyagi, I., Sadegh, H., Ghoshekand, R. S.-, Makhlouf, A. S. H., \& Maazinejad, B. (2015). Nanoparticles as Adsorbent; A Positive Approach for Removal of Noxious 
Metal Ions: A Review. Science, Technology and Development, 34(3), 195-214. https://doi.org/10.3923/std.2015.195.214

Haapanen, L., \& Tapio, P. (2016). Economic growth as phenomenon, institution and ideology: A qualitative content analysis of the 21 st century growth critique. Journal of Cleaner Production, 112, 3492-3503. https://doi.org/10.1016/j.jclepro.2015.10.024

Han, S., Cheng, J., Fan, H., Yu, J., \& Li, L. (2016). Achievement of High-Response Organic Field-Effect Transistor NO2 Sensor by Using the Synergistic Effect of ZnO/PMMA Hybrid Dielectric and CuPc/Pentacene Heterojunction. Sensors, 16(10), 1763. https://doi.org/10.3390/s16101763

Harish, S., Archana, J., Navaneethan, M., Ponnusamy, S., Singh, A., Gupta, V., Aswal, D. K., Ikeda, H., \& Hayakawa, Y. (2017). Synergetic effect of CuS@ZnS nanostructures on photocatalytic degradation of organic pollutant under visible light irradiation. $R S C$ Advances, 7(55), 34366-34375. https://doi.org/10.1039/c7ra04250g

He, F., Zhao, D., Liu, J., \& Roberts, C. B. (2007). Stabilization of Fe-Pd Nanoparticles with Sodium Carboxymethyl Cellulose for Enhanced Transport and Dechlorination of Trichloroethylene in Soil and Groundwater. Industrial \& Engineering Chemistry Research, 46(1), 29-34. https://doi.org/10.1021/ie0610896

He, S., Hou, P., Petropoulos, E., Feng, Y., Yu, Y., Xue, L., \& Yang, L. (2018). High Efficient Visible-Light Photocatalytic Performance of $\mathrm{Cu} / \mathrm{ZnO} / \mathrm{rGO}$ Nanocomposite for Decomposing of Aqueous Ammonia and Treatment of Domestic Wastewater. Frontiers in Chemistry, 6, 219. https://doi.org/10.3389/fchem.2018.00219

Hernandez-Vargas, G., Sosa-Hernández, J. E., Saldarriaga-Hernandez, S., VillalbaRodríguez, A. M., Parra-Saldivar, R., \& Iqbal, H. M. N. (2018). Electrochemical 
biosensors: A solution to pollution detection with reference to environmental contaminants. Biosensors 8(2). https://doi.org/10.3390/bios8020029

Hoffmann, M. R., Martin, S. T., Choi, W., \& Bahnemann, D. W. (1995). Environmental Applications of Semiconductor Photocatalysis. Chemical Reviews, 95(1), 69-96. https://doi.org/10.1021/cr00033a004

Hu, Z., Ma, Z., He, X., Liao, C., Li, Y., \& Qiu, J. (2015). Preparation and characterization of flexible and thermally stable $\mathrm{CuO}$ nanocrystal-decorated $\mathrm{SiO} 2$ nanofibers. Journal of Sol-Gel Science and Technology, 76(3), 492-500. https://doi.org/10.1007/s10971-0153799-9

Huang, J., Lin, W., \& Chen, J. (2014). Synthesis of CdIn2S4 microsphere and its photocatalytic activity for Azo dye degradation. The Scientific World Journal, 2014, 241234. https://doi.org/10.1155/2014/241234

Hughes, D. L., Afsar, A., Laventine, D. M., Shaw, E. J., Harwood, L. M., \& Hodson, M. E. (2018). Metal removal from soil leachates using DTPA-functionalised maghemite nanoparticles, a potential soil washing technology. Chemosphere, 209, 480-488. https://doi.org/10.1016/j.chemosphere.2018.06.121

Hussain, A., Ali, S., Rizwan, M., Rehman, M. Z. ur, Qayyum, M. F., Wang, H., \& Rinklebe, J. (2019). Responses of wheat (Triticum aestivum) plants grown in a Cd contaminated soil to the application of iron oxide nanoparticles. Ecotoxicology and Environmental Safety, 173, 156-164. https://doi.org/10.1016/j.ecoenv.2019.01.118

Jalal, A. H., Alam, F., Roychoudhury, S., Umasankar, Y., Pala, N., \& Bhansali, S. (2018). Prospects and Challenges of Volatile Organic Compound Sensors in Human Healthcare. In ACS Sensors 3(7), 1246-1263. https://doi.org/10.1021/acssensors.8b00400 
Jang, B., Kim, M. H., Baek, J., Kim, W., \& Lee, W. (2018). Chemical Highly sensitive hydrogen sensors : Pd-coated Si nanowire arrays for detection of dissolved hydrogen in oil. Sensors \& Actuators: B. Chemical, 273, 809-814. https://doi.org/10.1016/j.snb.2018.06.111

Jayaraj, R., Megha, P., \& Sreedev, P. (2016). Organochlorine pesticides, their toxic effects on living organisms and their fate in the environment. Interdisciplinary Toxicology 9(3-4), 90-100. https://doi.org/10.1515/intox-2016-0012

Jiang, L., Wang, Y., \& Feng, C. (2012). Application of photocatalytic technology in environmental safety. Procedia Engineering, 45, 993-997. https://doi.org/10.1016/j.proeng.2012.08.271

Joseph, Y., Guse, B., Yasuda, A., \& Vossmeyer, T. (2004). Chemiresistor coatings from Ptand Au-nanoparticle/nonanedithiol films: Sensitivity to gases and solvent vapors. Sensors and Actuators, B: Chemical, 98(2-3), 188-195. https://doi.org/10.1016/j.snb.2003.10.006

Kalanur, S. S., Yoo, I. H., Park, J., \& Seo, H. (2017). Insights into the electronic bands of WO3/BiVO4/TiO2, revealing high solar water splitting efficiency. Journal of Materials Chemistry A, 5(4), 1455-1461. https://doi.org/10.1039/c6ta07592d

Karn, B., Kuiken, T., \& Otto, M. (2009). Nanotechnology and in Situ Remediation : A Review of the Benefits and Potential Risks. Environmental Health Perspectives, 117(12), 1823-1832. https://doi.org/10.1289/ehp.0900793

Kato, S., \& Mashio, F. (1964). Titanium Dioxide-Photocatalyzed Liquid Phase Oxidation of Tetralin. The Journal of the Society of Chemical Industry, Japan, 67(8), 1136-1140. https://doi.org/10.1246/nikkashi1898.67.8_1136 
Ke, X., Zhang, X., Zhao, J., Sarina, S., Barry, J., \& Zhu, H. (2013). Selective reductions using visible light photocatalysts of supported gold nanoparticles. Green Chemistry, 15(1), 236-244. https://doi.org/10.1039/c2gc36542a

Khajeh, M., Laurent, S., \& Dastafkan, K. (2013). Nanoadsorbents: Classification, preparation, and applications (with emphasis on aqueous media). Chemical Reviews, 113(10), 7728-7768. https://doi.org/10.1021/cr400086v

Khan, I., Saeed, K., \& Khan, I. (2019). Nanoparticles: Properties, applications and toxicities. In Arabian Journal of Chemistry, 12(7), 908-931. https://doi.org/10.1016/j.arabjc.2017.05.011

Khan, M. M., Adil, S. F., \& Al-Mayouf, A. (2015). Metal oxides as photocatalysts. Journal of Saudi Chemical Society, 19(5), 462-464. https://doi.org/10.1016/J.JSCS.2015.04.003

Khan, M. M., Ansari, S. A., Lee, J.-H., Ansari, M. O., Lee, J., \& Cho, M. H. (2014). Electrochemically active biofilm assisted synthesis of $\mathrm{Ag} @ \mathrm{CeO} 2$ nanocomposites for antimicrobial activity, photocatalysis and photoelectrodes. Journal of Colloid and Interface Science, 431, 255-263. https://doi.org/10.1016/j.jcis.2014.06.026

Khieu, D. Q., Thanh, M. T., Thien, T. V., Phong, N. H., Van, D. H., Du, P. D., \& Hung, N. P. (2018). Synthesis and Voltammetric Determination of Pb ( II ) Using a ZIF-8-Based Electrode. Journal of Chemistry, 2018, 1-12. https://doi.org/10.1155/2018/5395106

Khin, M. M., Nair, A. S., Babu, V. J., Murugan, R., \& Ramakrishna, S. (2012). A review on nanomaterials for environmental remediation. Energy and Environmental Science, 5(8), 8075-8109. https://doi.org/10.1039/c2ee21818f

Kiriakidis, G., \& Binas, V. (2014). Metal oxide semiconductors as visible light photocatalysts. Journal of the Korean Physical Society, 65(3), 297-302. 
https://doi.org/10.3938/jkps.65.297

Krishnan, S., Rawindran, H., Sinnathambi, C. M., \& Lim, J. W. (2017). Comparison of various advanced oxidation processes used in remediation of industrial wastewater laden with recalcitrant pollutants. IOP Conference Series: Materials Science and Engineering, 206(1), 012089. https://doi.org/10.1088/1757-899X/206/1/012089

Kuppusamy, S., Thavamani, P., Venkateswarlu, K., Lee, Y. B., Naidu, R., \& Megharaj, M. (2016). Remediation approaches for polycyclic aromatic hydrocarbons (PAHs) contaminated soils: Technological constraints, emerging trends and future directions. Chemosphere, 168, 1-25. https://doi.org/10.1016/j.chemosphere.2016.10.115

Kuswandi, B. (2016). Nanotechnology in Food Packaging: Nanoscience in Food and Agriculture 1. Springer, Cham. https://doi.org/10.1007/978-3-319-39303-2_6

Landman, A., Dotan, H., Shter, G. E., Wullenkord, M., Houaijia, A., Maljusch, A., Grader, G. S., \& Rothschild, A. (2017). Photoelectrochemical water splitting in separate oxygen and hydrogen cells. Nature Materials, 16(6), 646-651. https://doi.org/10.1038/nmat4876

Lang, Q., Han, L., Hou, C., Wang, F., \& Liu, A. (2016). Talanta A sensitive acetylcholinesterase biosensor based on gold nanorods modi fi ed electrode for detection of organophosphate pesticide. Talanta, 156-157, 34-41. https://doi.org/10.1016/j.talanta.2016.05.002

Li, B., Zhou, S., Wei, D., Long, J., Peng, L., Tie, B., Williams, P. N., \& Lei, M. (2019). Mitigating arsenic accumulation in rice (Oryza sativa L.) from typical arsenic contaminated paddy soil of southern China using nanostructured $\alpha-\mathrm{MnO} 2$ : Pot experiment and field application. Science of the Total Environment, 650, 546-556. https://doi.org/10.1016/j.scitotenv.2018.08.436 
Li, P., Li, Y., Chen, S., Li, S., Jiang, M., Guo, Z., Liu, J., Huang, X., \& Yang, M. (2018). Chemical Sensitive and interference-free electrochemical determination of $\mathrm{Pb}$ ( II ) in wastewater using porous Ce-Zr oxide nanospheres. Sensors \& Actuators: B. Chemical, 257, 1009-1020. https://doi.org/10.1016/j.snb.2017.11.061

Li, Q., Chen, X., Zhuang, J., \& Chen, X. (2016). Decontaminating soil organic pollutants with manufactured nanoparticles. Environmental Science and Pollution Research, 23(12), 11533-11548. https://doi.org/10.1007/s11356-016-6255-7

Li, S., Li, W., Jiang, T., Liu, Z., Chen, X., Cong, H., Liu, J., Huang, Y., Li, L., \& Huang, X. (2016). Iron Oxide with Di ff erent Crystal Phases ( $\alpha-$ and $\gamma-\mathrm{Fe} 2 \mathrm{O} 3$ ) in Electroanalysis and Ultrasensitive and Selective Detection of Lead(II): An Advancing Approach Using XPS and EXAFS. Analytical Chemistry, 88, 906-914. https://doi.org/10.1021/acs.analchem.5b03570

Li, Yiyang, Peng, Y. K., Hu, L., Zheng, J., Prabhakaran, D., Wu, S., Puchtler, T. J., Li, M., Wong, K. Y., Taylor, R. A., \& Tsang, S. C. E. (2019). Photocatalytic water splitting by $\mathrm{N}-\mathrm{TiO} 2$ on $\mathrm{MgO}$ (111) with exceptional quantum efficiencies at elevated temperatures. Nature Communications, 10(1), 1-9. https://doi.org/10.1038/s41467-019-12385-1

Li, Yunguo, Li, Y. L., Araujo, C. M., Luo, W., \& Ahuja, R. (2013). Single-layer MoS2 as an efficient photocatalyst. Catalysis Science and Technology, 3(9), 2214-2220. https://doi.org/10.1039/c3cy00207a

Li, Yuxiu, Chen, N., Deng, D., Xing, X., Xiao, X., \& Wang, Y. (2017). Formaldehyde detection: $\mathrm{SnO} 2$ microspheres for formaldehyde gas sensor with high sensitivity, fast response/recovery and good selectivity. Sensors and Actuators, B: Chemical, 238, 264273. https://doi.org/10.1016/j.snb.2016.07.051 
Li, Z., Li, H., Wu, Z., Wang, M., Luo, J., Torun, H., Hu, P., Yang, C., Grundmann, M., Liu, X., \& Fu, Y. (2019). Advances in designs and mechanisms of semiconducting metal oxide nanostructures for high-precision gas sensors operated at room temperature. Materials Horizons, 6(3), 470-506). https://doi.org/10.1039/c8mh01365a

Liao, C., Ma, Z., Dong, G., \& Qiu, J. (2015). Flexible porous SiO2-Bi2WO6 nanofibers film for visible-light photocatalytic water purification. Journal of the American Ceramic Society, 98(3), 957-964. https://doi.org/10.1111/jace.13388

Liu, C., Meng, D., Li, Y., Wang, L., Liu, Y., \& Luo, S. (2015). Hierarchical architectures of ZnS-In2S3 solid solution onto $\mathrm{TiO} 2$ nanofibers with high visible-light photocatalytic activity. Journal of Alloys and Compounds, 624, 44-52. https://doi.org/10.1016/j.jallcom.2014.11.096

Liu, F., Xu, B., He, Y., Brookes, P. C., \& Xu, J. (2019). Co-transport of phenanthrene and pentachlorophenol by natural soil nanoparticles through saturated sand columns. Environmental Pollution, 249, 406-413. https://doi.org/10.1016/j.envpol.2019.03.052

Liu, Jie, Chen, T., Qi, Z., Yan, J., Buekens, A., \& Li, X. (2014). Thermal desorption of PCBs from contaminated soil using nano zerovalent iron. Environ Sci Pollut Res, 21, 1273912746. https://doi.org/10.1007/s11356-014-3226-8

Liu, Junyi, Huang, H., Zhong, S., She, X., \& Yin, D. (2016). Electrochemical Simultaneously Determination of Phenol and $\mathrm{o}-$ Cresol in Water Based on $\mathrm{ZnO}$ Nanosheets. International Journal of EChemical SciencesChemical Sciences, 11, 3921-3930. https://doi.org/10.20964/110497

Liu, N., Häublein, V., Zhou, X., Venkatesan, U., Hartmann, M., MačKović, M., Nakajima, T., Spiecker, E., Osvet, A., Frey, L., \& Schmuki, P. (2015). "Black" TiO2 Nanotubes 
Formed by High-Energy Proton Implantation Show Noble-Metal-co-Catalyst Free Photocatalytic H2-Evolution. Nano Letters, 15(10), 6815-6820. https://doi.org/10.1021/acs.nanolett.5b02663

Liu, X., Ma, R., Wang, X., Ma, Y., Yang, Y., Zhuang, L., Zhang, S., Jehan, R., Chen, J., \& Wang, X. (2019). Graphene oxide-based materials for efficient removal of heavy metal ions from aqueous solution: A review. Environ. Pollut., 252, 62-73. https://doi.org/10.1016/j.envpol.2019.05.050

Liu, Y., Zeng, X., Hu, X., Hu, J., \& Zhang, X. (2019). Two-dimensional nanomaterials for photocatalytic water disinfection: recent progress and future challenges. Journal of Chemical Technology \& Biotechnology, 94, 22-37. https://doi.org/10.1002/jctb.5779

Long, Y., Zhang, C., Du, Y., Tao, X., \& Shen, D.-S. (2013). Enhanced reductive dechlorination of polychlorinated biphenyl-contaminated soil by in-vessel anaerobic composting with zero-valent iron. Environ Sci Pollut Res, 21, 4783-4792. https://doi.org/10.1007/s11356-013-2420-4

Lu, H. J., Wang, J. K., Ferguson, S., Wang, T., Bao, Y., \& Hao, H. X. (2016). Mechanism, synthesis and modification of nano zerovalent iron in water treatment. Nanoscale, 8(19), 9962-9975. https://doi.org/10.1039/c6nr00740f

Ludlow, A., \& Roux, P. (2012). Innovative Technologies for Sustainable Environmental Remediation in Poor and Middle Income Countries. Journal of Health and Pollution, 2(3), 1-4. https://doi.org/10.5696/2156-9614-2.3.1

Ma, J., Yu, F., Zhou, L., Jin, L., Yang, M., Luan, J., Tang, Y., Fan, H., Yuan, Z., \& Chen, J. (2012). Enhanced Adsorptive Removal of Methyl Orange and Methylene Blue from Aqueous Solution by Alkali-Activated Multiwalled Carbon Nanotubes. ACS 
Publications, 4(11), 5749-5760. https://doi.org/10.1021/am301053m

Machado, S., Stawi, W., Slonina, P., Pinto, A. R., Grosso, J. P., Nouws, H. P. A., Albergaria, J. T., \& Delerue-matos, C. (2013). Application of green zero-valent iron nanoparticles to the remediation of soils contaminated with ibuprofen. Science of the Total Environment, 461-462, 323-329. https://doi.org/10.1016/j.scitotenv.2013.05.016

Mahlambi, M. M., Ngila, C. J., \& Mamba, B. B. (2015). Recent Developments in Environmental Photocatalytic Degradation of Organic Pollutants: The Case of Titanium Dioxide Nanoparticles-A Review. Journal of Nanomaterials, 2015, 790173. https://doi.org/10.1155/2015/790173

Mahmoodi, N. M., Arami, M., Limaee, N. Y., \& Gharanjig, K. (2007). Photocatalytic degradation of agricultural N-heterocyclic organic pollutants using immobilized nanoparticles of titania. Journal of Hazardous Materials, 145(1-2), 65-71. https://doi.org/10.1016/j.jhazmat.2006.10.089

Mahmoodi, N. M., Arami, M., Limaee, N. Y., Gharanjig, K., \& Nourmohammadian, F. (2007). Nanophotocatalysis using immobilized titanium dioxide nanoparticle. Degradation and mineralization of water containing organic pollutant: Case study of Butachlor. Materials Research Bulletin, 42(5), 797-806. https://doi.org/10.1016/j.materresbull.2006.08.031

Marsolek, M. D., Torres, C. I., Hausner, M., \& Rittmann, B. E. (2008). Intimate coupling of photocatalysis and biodegradation in a photocatalytic circulating-bed biofilm reactor. Biotechnology and Bioengineering, 101(1), 83-92. https://doi.org/10.1002/bit.21889

Medina-Pérez, G., Fernández-Luqueño, F., Vazquez-Nuñez, E., López-Valdez, F., PrietoMendez, J., Madariaga-Navarrete, A., \& Miranda-Arámbula, M. (2019). Remediating 
Polluted Soils Using Nanotechnologies: Environmental Benefits and Risks. Pol. J. Environ. Stud., 28(3), 1-18. https://doi.org/10.15244/pjoes/87099

Mehraj, O., Mir, N. A., Pirzada, B. M., \& Sabir, S. (2015). Fabrication of novel Ag 3 PO 4 /BiOBr heterojunction with high stability and enhanced visible-light-driven photocatalytic activity. Applied Surface Science, 332, 419-429. https://doi.org/10.1016/j.apsusc.2015.01.163

Mehraj, O., Mir, N. A., Pirzada, B. M., Sabir, S., \& Muneer, M. (2014). In-situ anion exchange synthesis of $\mathrm{AgBr} / \mathrm{Ag} 2 \mathrm{CO} 3$ hybrids with enhanced visible light photocatalytic activity and improved stability. Journal of Molecular Catalysis A: Chemical, 395, 1624. https://doi.org/10.1016/j.molcata.2014.07.027

Mehraj, O., Pirzada, B. M., Mir, N. A., Khan, M. Z., \& Sabir, S. (2016). A highly efficient visible-light-driven novel p-n junction Fe 2 O 3 /BiOI photocatalyst: Surface decoration of BiOI nanosheets with Fe 2 O 3 nanoparticles. Applied Surface Science, 387, 642-651. https://doi.org/10.1016/j.apsusc.2016.06.166

Mehraj, O., Pirzada, B. M., Mir, N. A., Sultana, S., \& Sabir, S. (2015). Ag2S sensitized mesoporous Bi2WO6 architectures with enhanced visible light photocatalytic activity and recycling properties. RSC Advances, 5(53), 42910-42921. https://doi.org/10.1039/c5ra05117g

Mehta, V. N., Kumar, M. A., \& Kailasa, S. K. (2013). Colorimetric detection of copper in water samples using dopamine dithiocarbamate-functionalized Au nanoparticles. Industrial and Engineering Chemistry Research, 52(12), 4414-4420. https://doi.org/10.1021/ie302651f

Moharem, M., Elkhatib, E., \& Mesalem, M. (2019). Remediation of chromium and mercury 
polluted calcareous soils using nanoparticles : Sorption-desorption kinetics, speciation and fractionation. Environmental Research, 170, 366-373. https://doi.org/10.1016/j.envres.2018.12.054

Mondal, A., Basu, R., Das, S., \& Nandy, P. (2011). Beneficial role of carbon nanotubes on mustard plant growth: An agricultural prospect. Journal of Nanoparticle Research, 13, 4519. https://doi.org/10.1007/s11051-011-0406-Z

Moradi, O. (2013). Adsorption Behavior of Basic Red 46 by Single-Walled Carbon Nanotubes Surfaces, Fullerenes, Nanotubes and Carbon Nanostructures. Taylor \& Francis, 21(4), 286-301. https://doi.org/10.1080/1536383X.2011.572317

Moseley, P. T. (2017). Progress in the development of semiconducting metal oxide gas sensors: a review. Measurement Science and Technology, 28(8), 082001. https://doi.org/10.1088/1361-6501/AA7443

Moussa, S. I., Sheha, R. R., Saad, E. A., \& Tadros, N. A. (2013). Synthesis and characterization of magnetic nano-material for removal of Eu3+ ions from aqueous solutions. Journal of Radioanalytical and Nuclear Chemistry, 295(2), 929-935. https://doi.org/10.1007/s10967-012-1908-6

Mugunthan, E., Saidutta, M. B., \& Jagadeeshbabu, P. E. (2018). Visible light assisted photocatalytic degradation of diclofenac using TiO2-WO3 mixed oxide catalysts. Environmental Nanotechnology, Monitoring and Management, 10, 322-330. https://doi.org/10.1016/j.enmm.2018.07.012

Mukhopadhyay, S. S. (2014). Nanotechnology in agriculture. Prospects and constraints: Nanotechnology, Science and Applications, 2017, 63-71. https://doi.org/10.2147/NSA.S39409 
Nguyen, S. N., Truong, T. K., You, S.-J., Wang, Y.-F., Cao, T. M., \& Pham, V. Van. (2019). Investigation on Photocatalytic Removal of NO under Visible Light over Cr-Doped ZnO Nanoparticles. $\quad$ ACS $\quad$ Omega, $\quad 4(7), \quad 12853-12859$. https://doi.org/10.1021/acsomega.9b01628

Nithya, M. (2015). Electrochemical Sensing of Ascorbic Acid on ZnO-decorated Reduced Graphene Oxide Electrode Biosensors \& Bioelectronics. Journal of Biosensors \& Bioelectronics, 6(1), 1-9. https://doi.org/10.4172/2155-6210.1000164

Omar, O. (2018). Towards eco-neighborhoods, solutions for sustainable development, construction and energy saving technologies. Journal of Architecture and Urbanism, 42(2), 95-102. https://doi.org/10.3846/jau.2018.6141

Özlem Kocabaş-Atakli, Z., \& Yürüm, Y. (2013). Synthesis and characterization of anatase nanoadsorbent and application in removal of lead, copper and arsenic from water. Chemical Engineering Journal, 225, 625-635. https://doi.org/10.1016/j.cej.2013.03.106

Paerl, H. W., Otten, T. G., \& Kudela, R. (2018). Mitigating the Expansion of Harmful Algal Blooms Across the Freshwater-to-Marine Continuum. Environmental Science and Technology, 52(10), 5519-5529. https://doi.org/10.1021/acs.est.7b05950

Pan, B., \& Xing, B. (2012). Applications and implications of manufactured nanoparticles in soils: a review. European Journal of Soil Science, 63, 437-456. https://doi.org/10.1111/j.1365-2389.2012.01475.x

Pan, S., Shen, H., Xu, Q., Luo, J., \& Hu, M. (2012). Surface mercapto engineered magnetic $\mathrm{Fe} 3 \mathrm{O} 4$ nanoadsorbent for the removal of mercury from aqueous solutions. Journal of Colloid and Interface Science, 365(1), 204-212. https://doi.org/10.1016/j.jcis.2011.09.002 
Parthibavarman, M., Sathishkumar, S., \& Prabhakaran, S. (2018). Enhanced visible light photocatalytic activity of tin oxide nanoparticles synthesized by different microwave optimum conditions. Journal of Materials Science: Materials in Electronics, 29(3), 2341-2350. https://doi.org/10.1007/s10854-017-8152-3

Patil, S. S., Shedbalkar, U. U., Truskewycz, A., Chopade, B. A., \& Ball, A. S. (2016). Nanoparticles for environmental clean-up: A review of potential risks and emerging solutions. Environmental Technology and Innovation 5, 10-21. https://doi.org/10.1016/j.eti.2015.11.001

PEN, 2015. The Project on Emerging Nanotechnologies. Nanoremediation Map. http://www.nanotechproject.org/inventories/remediation_map/

Peikam, E. N., \& Jalali, M. (2018). Application of three nanoparticles - ( Al2O3, - SiO2 and $\mathrm{TiO} 2$ ) for metal-contaminated soil remediation (measuring and modeling). International Journal of Environmental Science and Technology, 16, 7207-7220 https://doi.org/10.1007/s13762-018-2134-8

Pirzada, B. M., Mehraj, O., Mir, N. A., Khan, M. Z., \& Sabir, S. (2015). Efficient visible light photocatalytic activity and enhanced stability of $\mathrm{BiOBr} / \mathrm{Cd}(\mathrm{OH}) 2$ heterostructures. New Journal of Chemistry, 39(9), 7153-7163. https://doi.org/10.1039/c5nj00839e

Pirzada, B. M., Mir, N. A., Qutub, N., Mehraj, O., Sabir, S., \& Muneer, M. (2015). Synthesis, characterization and optimization of photocatalytic activity of $\mathrm{TiO} 2 / \mathrm{ZrO} 2$ nanocomposite heterostructures. Materials Science and Engineering B: Solid-State Materials for Advanced Technology, 193(C), 137-145. https://doi.org/10.1016/j.mseb.2014.12.005

Prasad, R., Bhattacharyya, A., \& Nguyen, Q. D. (2017). Nanotechnology in sustainable 
agriculture: Recent developments, challenges, and perspectives. Frontiers in Microbiology, 8, 1014. https://doi.org/10.3389/fmicb.2017.01014

Pulimi, M., \& Subramanian, S. (2016). Nanomaterials for Soil Fertilisation. Nanoscience in Food and Agriculture 1, 229-246. Springer International Publishing Switzerland 2016. https://doi.org/10.1007/978-3-319-39303-2

Qiao, Y., Wu, J., Xu, Y., Fang, Z., Zheng, L., Cheng, W., Tsang, E. P., Fang, J., \& Zhao, D. (2017). Remediation of cadmium in soil by biochar-supported iron phosphate nanoparticles. Ecological Engineering, 515-522. https://doi.org/10.1016/j.ecoleng.2017.06.023

Qin, W., Liu, X., \& Yang, J. (2014). Amperometric sensors for detection of phenol in oil fi eld wastewater using electrochemical polymerization of zincon fi $1 \mathrm{~m}$. Analytical Methods, 6, 5734-5740. https://doi.org/10.1039/c3ay41855c

Qutub, N., Pirzada, B. M., Umar, K., \& Sabir, S. (2016). Synthesis of CdS nanoparticles using different sulfide ion precursors: Formation mechanism and photocatalytic degradation of Acid Blue-29. Journal of Environmental Chemical Engineering, 4(1), 808-817. https://doi.org/10.1016/j.jece.2015.10.031

Rahman, M. M., Jamal, A., Khan, S. B., \& Faisal, M. (2011). CuO Codoped ZnO Based Nanostructured Materials for Sensitive Chemical Sensor Applications. ACS Applied Materials \& Interfaces, 3(4), 1346-1351. https://doi.org/10.1021/am200151f

Rajamanickam, D., \& Shanthi, M. (2016). Photocatalytic degradation of an organic pollutant by zinc oxide - solar process. Arabian Journal of Chemistry, 9, S1858-S1868. https://doi.org/10.1016/j.arabjc.2012.05.006

Rajan, C. S. (2011). Nanotechnology in Groundwater Remediation. International Journal of 
Environmental Science and Development, 2, 182-187. https://doi.org/10.7763/ijesd.2011.v2.121

Razmi, H., Ezzati, L., \& Khorablou, Z. (2019). Direct Electrochemical Synthesis of Graphene Oxide/Cobalt Oxide Nanocomposite on Pencil Graphite Electrode for Highly Sensitive and Selective Detection of Insulin in Pharmaceutical Samples. Journal of The Electrochemical Society, 166(12), B961-B968. https://doi.org/10.1149/2.0621912jes

Regmi, C., Dhakal, D., \& Lee, S. W. (2018). Visible-light-induced Ag/BiVO4 semiconductor with enhanced photocatalytic and antibacterial performance. Nanotechnology, 29(6), 064001. https://doi.org/10.1088/1361-6528/AAA052

Regmi, C., Joshi, B., Ray, S. K., Gyawali, G., \& Pandey, R. P. (2018). Understanding Mechanism of Photocatalytic Microbial Decontamination of Environmental Wastewater. Frontiers in Chemistry, 6, 33. https://doi.org/10.3389/fchem.2018.00033

Regmi, C., Kim, T. H., Ray, S. K., Yamaguchi, T., \& Lee, S. W. (2017). Cobalt-doped BiVO4 (Co-BiVO4) as a visible-light-driven photocatalyst for the degradation of malachite green and inactivation of harmful microorganisms in wastewater. Research on Chemical Intermediates, 43(9), 5203-5216. https://doi.org/10.1007/s11164-017-3036-y

Regmi, C., Kshetri, Y. K., Kim, T. H., Pandey, R. P., Ray, S. K., \& Lee, S. W. (2017). Fabrication of Ni-doped BiVO4 semiconductors with enhanced visible-light photocatalytic performances for wastewater treatment. Applied Surface Science, 413, 253-265. https://doi.org/10.1016/j.apsusc.2017.04.056

Rincón Joya, M., Barba Ortega, J., Malafatti, J. O. D., \& Paris, E. C. (2019). Evaluation of Photocatalytic Activity in Water Pollutants and Cytotoxic Response of $\alpha$-Fe ${ }_{2} \mathrm{O}_{3}$ Nanoparticles. $\quad$ OCS $\quad$ Omega, $\quad 4(17), \quad 17477-17486$. 
https://doi.org/10.1021/acsomega.9b02251

Roco, M. C. (2005). International perspective on government nanotechnology funding in 2005. Journal of Nanoparticle Research, 7(6), 707-712. https://doi.org/10.1007/s11051$005-3141-5$

Rosen, M. A., \& Koohi-Fayegh, S. (2016). The prospects for hydrogen as an energy carrier: an overview of hydrogen energy and hydrogen energy systems. Energy, Ecology and Environment, 1(1) 10-29. https://doi.org/10.1007/s40974-016-0005-z

Sachs, J., Schmidt-Traub, G., Kroll, C., Lafortune, G., \& Fuller, G. (2019). Sustainable development report 2019.

Sakimoto, K. K., Zhang, S. J., \& Yang, P. (2016). Cysteine-Cystine Photoregeneration for Oxygenic Photosynthesis of Acetic Acid from CO2 by a Tandem Inorganic-Biological $\begin{array}{llll}\text { Hybrid System. } & \text { Nano }\end{array}$ https://doi.org/10.1021/acs.nanolett.6b02740

Salata, O. V. (2004). Applications of nanoparticles in biology and medicine. Journal of Nanobiotechnology, 2(1), 3. https://doi.org/10.1186/1477-3155-2-3

Sankar ganesh, R., Navaneethan, M., Mani, G. K., Ponnusamy, S., Tsuchiya, K., Muthamizhchelvan, C., Kawasaki, S., \& Hayakawa, Y. (2017). Influence of Al doping on the structural, morphological, optical, and gas sensing properties of $\mathrm{ZnO}$ nanorods. Journal of Alloys and Compounds, 698, 555-564. https://doi.org/10.1016/j.jallcom.2016.12.187

Schneider, J. J., \& Naumann, M. (2014). Template-directed synthesis and characterization of microstructured ceramic $\mathrm{Ce} / \mathrm{ZrO}_{2} @_{\mathrm{SiO}} 2$ composite tubes. Beilstein Journal of Nanotechnology, 5(1), 1152-1159. https://doi.org/10.3762/bjnano.5.126 
Seiyama, T., Kato, A., Fujiishi, K., \& Nagatani, M. (1962). A New Detector for Gaseous Components Using Semiconductive Thin Films. Analytical Chemistry, 34(11), 15021503. https://doi.org/10.1021/ac60191a001

Shafi, A., Ahmad, N., Sultana, S., Sabir, S., \& Khan, M. Z. (2019). Ag2S-sensitized NiO$\mathrm{ZnO}$ heterostructures with enhanced visible light photocatalytic activity and acetone sensing property. ACS Omega, 4(7), 12905-12918. https://doi.org/10.1021/acsomega.9b01261

Shafi, A., Bano, S., Sabir, S., Khan, M. Z., \& Rahman, M. M. (2020a). Carbon-Based material for Environmental Protection and Remediation. Intechopen. http://doi.org/10.5772/intechopen.89474

Shafi, A., Qadir, J., Sabir, S., Khan, M. Z., \& Rahman, M. M. (2020b). Handbook of nanomaterials and Nanocomposites for energy and environmental Applications. Springer Nature. https://doi.org/10.1007/978-3-030-11155-7_48-1

Shang, L., Xu, J., \& Nienhaus, G. U. (2019). Recent advances in synthesizing metal nanocluster-based nanocomposites for application in sensing, imaging and catalysis. Nano Today, 28, 100767. https://doi.org/10.1016/j.nantod.2019.100767

Sharma, C., Dhiman, R., Rokana, N., \& Panwar, H. (2017). Nanotechnology: An untapped resource for food packaging. Frontiers in Microbiology, 8, 1735. https://doi.org/10.3389/fmicb.2017.01735

Sharma, S., \& Bhattacharya, A. (2017). Drinking water contamination and treatment techniques. Applied Water Science, 7(3), 1043-1067. https://doi.org/10.1007/s13201016-0455-7

Shi, H., Wang, T., Chen, J., Zhu, C., Ye, J., \& Zou, Z. (2011). Photoreduction of carbon 
dioxide over NaNbO3 nanostructured photocatalysts. Catalysis Letters, 141(4), 525530. https://doi.org/10.1007/s10562-010-0482-1

Shields, M. W., Johnson, A. C., Pandey, S., Cullen, R., González-Chang, M., Wratten, S. D., \& Gurr, G. M. (2019). History, current situation and challenges for conservation biological control. Biological Control, $131, \quad 25-35$. https://doi.org/10.1016/j.biocontrol.2018.12.010

Shipley, H. J., Engates, K. E., \& Guettner, A. M. (2011). Study of iron oxide nanoparticles in soil for remediation of arsenic. $J$ Nanopart Res, 13, 2387-2397. https://doi.org/10.1007/s11051-010-9999-x

Shirmardi, M., Mesdaghinia, A., Mahvi, A.H., Nasseri, S. and Nabizadeh, R., (2012). Kinetics and equilibrium studies on adsorption of acid red 18 (Azo-Dye) using multiwall carbon nanotubes (MWCNTs) from aqueous solution. Journal of Chemistry, 9, 541909. https://doi.org/10.1155/2012/541909

Singh, P. P., \& Ambika. (2018). Environmental remediation by nanoadsorbents-based polymer nanocomposite. New Polymer Nanocomposites for Environmental Remediation, 223-241, Elsevier. https://doi.org/10.1016/B978-0-12-811033-1.00010-X

Smith, S. C., \& Rodrigues, D. F. (2015). Carbon-based nanomaterials for removal of chemical and biological contaminants from water: A review of mechanisms and applications. Carbon, 91, 122-143. https://doi.org/10.1016/j.carbon.2015.04.043

Solanki, P. R., Kaushik, A., Agrawal, V. V., \& Malhotra, B. D. (2011). Nanostructured metal oxide-based biosensors. NPG Asia Materials, 3(1), 17-24. https://doi.org/10.1038/asiamat.2010.137

Su, Hua, Fang, Y., Chen, F., \& Wang, W. (2018). Monitoring the dynamic photocatalytic 
activity of single CdS nanoparticles by lighting up $\mathrm{H} 2$ nanobubbles with fluorescent dyes. Chemical Science, 9(6), 1448-1453. https://doi.org/10.1039/c7sc04684g

Su, Huijie, Fang, Z., Tsang, P. E., Zheng, L., Cheng, W., Fang, J., \& Zhao, D. (2016). Remediation of hexavalent chromium contaminated soil by biochar-supported zerovalent iron nanoparticles. Journal of Hazardous Materials, 318, 533-540. https://doi.org/10.1016/j.jhazmat.2016.07.039

Sultana, S., Rafiuddin, Khan, M. Z., Umar, K., Ahmed, A. S., \& Shahadat, M. (2015). SnO2$\mathrm{SrO}$ based nanocomposites and their photocatalytic activity for the treatment of organic pollutants. Journal of Molecular Structure, 1098, 393-399. https://doi.org/10.1016/j.molstruc.2015.06.032

Sun, R., Chen, J., Fan, T., Zhou, D., \& Wang, Y. (2016). Effect of nanoparticle hydroxyapatite on the immobilization of $\mathrm{Cu}$ and $\mathrm{Zn}$ in polluted soil. Environmental Science and Pollution Research, 25, 73-80. https://doi.org/10.1007/s11356-016-8063-5

Suri, R. P. S., Liu, J., Crittenden, J. C., \& Hand, D. W. (1999). Removal and destruction of organic contaminants in water using adsorption, steam regeneration, and photocatalytic oxidation: A pilot-scale study. Journal of the Air and Waste Management Association, 49(8), 951-958. https://doi.org/10.1080/10473289.1999.10463861

Takata, T., \& Domen, K. (2019). Particulate Photocatalysts for Water Splitting: Recent Advances and Future Prospects. ACS Energy Letters, 4(2), 542-549. https://doi.org/10.1021/acsenergylett.8b02209

Tang, W., Su, Y., Li, Q., Gao, S., \& Shang, J. K. (2013). Superparamagnetic magnesium ferrite nanoadsorbent for effective arsenic (III, V) removal and easy magnetic separation. Water Research, 47(11), 3624-3634. 
https://doi.org/10.1016/j.watres.2013.04.023

Teow, Y. H., \& Mohammad, A. W. (2019). New generation nanomaterials for water $\begin{array}{lllll}\text { desalination: } & \text { a } & \text { review. } & \text { Desalination, }\end{array}$ https://doi.org/10.1016/j.desal.2017.11.041

Thangavel, P., \& Sridevi, G. (2015). Environmental sustainability: Role of green technologies. Environmental Sustainability: Role of Green Technologies. Springer India. https://doi.org/10.1007/978-81-322-2056-5

Tosco, T., Petrangeli Papini, M., Cruz Viggi, C., \& Sethi, R. (2014). Nanoscale zerovalent iron particles for groundwater remediation: A review. Journal of Cleaner Production, 77, 10-21. https://doi.org/10.1016/j.jclepro.2013.12.026

Travlou, N. A., Kyzas, G. Z., Lazaridis, N. K., \& Deliyanni, E. A. (2013). Functionalization of Graphite Oxide with Magnetic Chitosan for the Preparation of a Nanocomposite Dye Adsorbent. Langmuir, 29(5), 1657-1668. https://doi.org/10.1021/la304696y

Tresintsi, S., Simeonidis, K., Estradé, S., Martinez-Boubeta, C., Vourlias, G., Pinakidou, F., Katsikini, M., Paloura, E. C., Stavropoulos, G., \& Mitrakas, M. (2013). Tetravalent Manganese Feroxyhyte: A Novel Nanoadsorbent Equally Selective for As(III) and As(V) Removal from Drinking Water. Environmental Science \& Technology, 47(17), 9699-9705. https://doi.org/10.1021/es4009932

US Environmental Protection Agency (USEPA), 2009. National priorities list (NPL). http://www.epa.gov/superfund/sites/npl/

Vasarevičius, S., Danila, V., \& Paliulis, D. (2019). Application of Stabilized Nano Zero Valent Iron Particles for Immobilization of Available $\mathrm{Cd} 2+, \mathrm{Cu} 2+, \mathrm{Ni} 2+$, and $\mathrm{Pb} 2+\mathrm{Ions}$ in Soil. International Journal of Environmental Research, 13, 465- 
Veerakumar, P., Chen, S., Madhu, R., Veeramani, V., Hung, C., \& Liu, S. (2015). Nickel nanoparticle-decorated porous carbons for highly active catalytic reduction of organic dyes and sensitive detection of $\mathrm{Hg}$ (II) ions. ACS applied materials \& interfaces, 7 , 24810-24821. https://doi.org/10.1021/acsami.5b07900

Veerakumar, P., Veeramani, V., Chen, S., Madhu, R., \& Liu, S. (2016). Palladium Nanoparticle Incorporated Porous Activated Carbon: Electrochemical Detection of Toxic Metal Ions. ACS applied materials \& interfaces, 8, 1319-1326. https://doi.org/10.1021/acsami.5b10050

Vikesland, P. J. (2018). Nanosensors for water quality monitoring. Nature Nanotechnology, 13(8), 651-660. https://doi.org/10.1038/s41565-018-0209-9

Vítková, M., Puschenreiter, M., \& Komárek, M. (2018). Effect of nano zero-valent iron application on $\mathrm{As}, \mathrm{Cd}, \mathrm{Pb}$, and $\mathrm{Zn}$ availability in the rhizosphere of metal(loid) contaminated $\quad$ soils. $\quad$ Chemosphere, 200, 217-226. https://doi.org/10.1016/j.chemosphere.2018.02.118

Wang, H., Kim, B., \& Wunder, S. L. (2015). Nanoparticle Supported Lipid Bilayers as an In Situ Remediation Strategy for Hydrophobic Organic Contaminants in Soils. Environ. Sci. Technol, 49, 529-536. https://doi.org/10.1021/es504832n

Wang, L., Huang, H., Xiao, S., Cai, D., Liu, Y., Liu, B., Wang, D., Wang, C., Li, H., Wang, Y., Li, Q., \& Wang, T. (2014). Enhanced Sensitivity and Stability of Room-Temperature NH 3 Sensors Using Core - Shell CeO 2 Nanoparticles @ Cross-linked PANI with p - n Heterojunctions. ACS Appl. Mater. Interfaces, 6, 14131-14140. https://doi.org/10.1021/am503286h 
Wang, M., Sun, L., Cai, J., Huang, P., Su, Y., \& Lin, C. (2013). A facile hydrothermal deposition of $\mathrm{ZnFe} 2 \mathrm{O} 4$ nanoparticles on $\mathrm{TiO} 2$ nanotube arrays for enhanced visible light photocatalytic activity. Journal of Materials Chemistry A, 1(39), 12082-12087. https://doi.org/10.1039/c3ta12577g

Wang, T., Huang, D., Yang, Z., Xu, S., He, G., Li, X., Hu, N., Yin, G., He, D., \& Zhang, L. (2016). A Review on Graphene-Based Gas/Vapor Sensors with Unique Properties and Potential Applications. Nano-Micro Letters, 8(2), 95-119. https://doi.org/10.1007/s40820-015-0073-1

Wang, Y., Shi, R., Lin, J., \& Zhu, Y. (2011). Enhancement of photocurrent and photocatalytic activity of $\mathrm{ZnO}$ hybridized with graphite-like $\mathrm{C} 3 \mathrm{~N} 4$. Energy and Environmental Science, 4(8), 2922-2929. https://doi.org/10.1039/c0ee00825g

Wang, Z., Li, C., \& Domen, K. (2019). Recent developments in heterogeneous photocatalysts for solar-driven overall water splitting. Chemical Society Reviews, 48(7), 2109-2125. https://doi.org/10.1039/c8cs00542g

Wolff, C. M., Frischmann, P. D., Schulze, M., Bohn, B. J., Wein, R., Livadas, P., Carlson, M. T., Jäckel, F., Feldmann, J., Würthner, F., \& Stolarczyk, J. K. (2018). All-in-one visiblelight-driven water splitting by combining nanoparticulate and molecular co-catalysts on CdS nanorods. Nature Energy, 3(10), 862-869. https://doi.org/10.1038/s41560-0180229-6

\begin{tabular}{lll|l} 
World Water Development $\quad$ Report $2019 \quad$ UN-Water.
\end{tabular} https://www.unwater.org/publications/world-water-development-report-2019/

Wu, C., Shen, L., Zhang, Y. C., \& Huang, Q. (2011). Solvothermal synthesis of Cr-doped $\mathrm{ZnO}$ nanowires with visible light-driven photocatalytic activity. Materials Letters, 
65(12), 1794-1796. https://doi.org/10.1016/j.matlet.2011.03.070

Wu, J., Yi, Y., Li, Y., Fang, Z., \& Pokeung Tsang, E. (2016). Excellently reactive Ni/Fe bimetallic catalyst supported by biochar for the remediation of decabromodiphenyl contaminated soil: Reactivity, mechanism, pathways and reducing secondary risks. Journal of Hazardous $\quad$ Materials, $340, \quad 349$. https://doi.org/10.1016/j.jhazmat.2016.08.049

Wu, Y., Pang, H., Liu, Y., Wang, X., Yu, S., Fu, D., Chen, J., \& Wang, X. (2019). Environmental remediation of heavy metal ions by novel-nanomaterials: A review. In Environmental Pollution, 246, 608-620. https://doi.org/10.1016/j.envpol.2018.12.076

Xie, Yingying, Cheng, W., Tsang, P. E., \& Fang, Z. (2016). Remediation and phytotoxicity of decabromodiphenyl ether contaminated soil by zero valent iron nanoparticles immobilized in mesoporous silica microspheres. Journal of Environmental Management, 166, 478-483. https://doi.org/10.1016/j.jenvman.2015.10.042

Xie, Yu, Yu, Y., Lu, L., Ma, X., Gong, L., Huang, X., Liu, G., \& Yu, Y. (2018). CuO nanoparticles decorated 3D graphene nanocomposite as non-enzymatic electrochemical sensing platform for malathion detection. Journal of Electroanalytical Chemistry, 812, 82-89. https://doi.org/10.1016/j.jelechem.2018.01.043

Xu, T., Hu, J., Yang, Y., Que, W., Yin, X., Wu, H., \& Chen, L. (2018). Ternary system of $\mathrm{ZnO}$ nanorods/reduced graphene oxide/CuInS2 quantum dots for enhanced photocatalytic performance. Journal of Alloys and Compounds, 734, 196-203. https://doi.org/10.1016/j.jallcom.2017.10.275

Xu, Y., Yan, X., Fan, L., \& Fang, Z. (2016). Remediation of Cd (II) -contaminated soil by three kinds of ferrous phosphate nanoparticles. RSC Advances, 6, 17390-17395. 
https://doi.org/10.1039/C5RA23299F

Xue, W., Huang, D., Zeng, G., Wan, J., Cheng, M., Zhang, C., Hu, C., \& Li, J. (2018). Performance and toxicity assessment of nanoscale zero valent iron particles in the remediation of contaminated soil: a review. Chemosphere, 210, 1145-1156. https://doi.org/10.1016/j.chemosphere.2018.07.118

Yan, Z., Xue, H., Berning, K., Lam, Y., \& Lee, C. (2014). Identi fi cation of Multifunctional Graphene - Gold Nanocomposite for Environment-Friendly Enriching, Separating, and Detecting Hg 2 + Simultaneously. ACS Appl. Mater. Interfaces, 4, 22761-22768. https://doi.org/10.1021/am506875t

Yang, H., \& Yang, J. (2018). Photocatalytic degradation of rhodamine B catalyzed by TiO2 films on a capillary column. RSC Advances, 8(22), 11921-11929. https://doi.org/10.1039/c8ra00471d

Yang, L., Luo, S., Li, Y., Xiao, Y., Kang, Q., \& Cai, Q. (2010). High efficient photocatalytic degradation of p-nitrophenol on a unique $\mathrm{Cu} 2 \mathrm{O} / \mathrm{TiO} 2 \mathrm{p}-\mathrm{n}$ heterojunction network catalyst. Environmental Science and Technology, 44(19), 7641-7646. https://doi.org/10.1021/es101711k

Yao, W., Zhang, B., Huang, C., Ma, C., Song, X., \& Xu, Q. (2012). Synthesis and characterization of high efficiency and stable Ag 3PO 4/TiO 2 visible light photocatalyst for the degradation of methylene blue and rhodamine B solutions. Journal of Materials Chemistry, 22(9), 4050-4055. https://doi.org/10.1039/c2jm14410g

Yeung, A. T. (2010). Remediation Technologies for Contaminated Sites. Advances in Environmental Geotechnics, 328-369. Springer Berlin Heidelberg. https://doi.org/10.1007/978-3-642-04460-1_25 
Zhang, C., Chen, L., Wang, T. J., Su, C. L., \& Jin, Y. (2014). Synthesis and properties of a magnetic core-shell composite nano-adsorbent for fluoride removal from drinking water. Applied Surface Science, 317, 552-559. https://doi.org/10.1016/j.apsusc.2014.08.143

Zhang, Min, Liu, Y. Q., \& Ye, B. C. (2012). Colorimetric assay for parallel detection of $\mathrm{Cd} 2+, \mathrm{Ni} 2+$ and $\mathrm{Co} 2+$ using peptide-modified gold nanoparticles. Analyst, 137(3), 601607. https://doi.org/10.1039/c1an15909g

Zhang, Mingyi, Liu, Y., Li, L., Gao, H., \& Zhang, X. (2015). BiOCl nanosheet/Bi4Ti3O12 nanofiber heterostructures with enhanced photocatalytic activity. Catalysis Communications, 58, 122-126. https://doi.org/10.1016/j.catcom.2014.09.021

Zhang, W., Wang, L., Shen, H., \& Wang, Y. (2015). Supporting TiO2 on multiwalled carbon nanotube-doped $\mathrm{A} 12 \mathrm{O} 3$ for the enhancement of the photocatalytic degradation of methyl orange. Reaction Kinetics, Mechanisms and Catalysis, 116(2), 577-588. https://doi.org/10.1007/s11144-015-0899-z

Zhang, X., \& Liu, Y. (2020). Nanomaterials for radioactive wastewater decontamination. Environmental Science: Nano, 7(4), 1008-1040. https://doi.org/10.1039/c9en01341e

Zhao, D., He, Z., Wang, G., Wang, H., Zhang, Q., \& Li, Y. (2016). A novel efficient $\mathrm{ZnO} / \mathrm{Zn}(\mathrm{OH}) \mathrm{F}$ nanofiber arrays-based versatile microfluidic system for the applications of photocatalysis and histidine-rich protein separation. Sensors and Actuators, B: Chemical, 229, 281-287. https://doi.org/10.1016/j.snb.2016.01.125

Zhao, Y., Tao, C., Xiao, G., Wei, G., Li, L., Liu, C., \& Su, H. (2016). Controlled synthesis and photocatalysis of sea urchin-like Fe3O4@TiO2@Ag nanocomposites. Nanoscale, 8(9), 5313-5326. https://doi.org/10.1039/c5nr08624h

Zhong, X., Liang, W., Wang, H., Xue, C., Hu, B., 2021. Aluminum-based metal-organic 
frameworks (CAU-1) highly efficient $\mathrm{UO} 22+$ and $\mathrm{TcO} 4-$ ions immobilization from aqueous solution. Journal of Hazardous Materials, 407, 124729. https://doi.org/10.1016/j.jhazmat.2020.124729

Zhong, X., Lu, Z., Liang, W., Hu, B., 2020. The magnetic covalent organic framework as a platform for high-performance extraction of $\mathrm{Cr}(\mathrm{VI})$ and bisphenol a from aqueous $\begin{array}{lllll}\text { solution. Journal of } & \text { Hazardous }\end{array}$ https://doi.org/10.1016/j.jhazmat.2020.122353

Zhou, G., Chang, J., Pu, H., Shi, K., Mao, S., Sui, X., Ren, R., Cui, S., \& Chen, J. (2016). Ultrasensitive Mercury Ion Detection Using DNA-Functionalized Molybdenum Disul fi 00de Nanosheet/Gold Nanoparticle Hybrid Field- E ff ect Transistor Device. ACS Sensors, 1, 295-302. https://doi.org/10.1021/acssensors.5b00241

Zhu, H., Ke, X., Yang, X., Sarina, S., \& Liu, H. (2010). Reduction of nitroaromatic compounds on supported gold nanoparticles by visible and ultraviolet light. Angewandte Chemie - International Edition, 49(50), 9657-9661. https://doi.org/10.1002/anie.201003908 